UNIVERSITY OF CALIFORNIA

COLLEGE OF AGRICULTURE

AGRICULTURAL EXPERIMENT STATION

BERKELEY, CALIFORNIA

\title{
Composition of \\ Common California Foothill Plants as a Factor in Range Management
}

\section{AARON GORDON and ARTHUR W. SAMPSON}

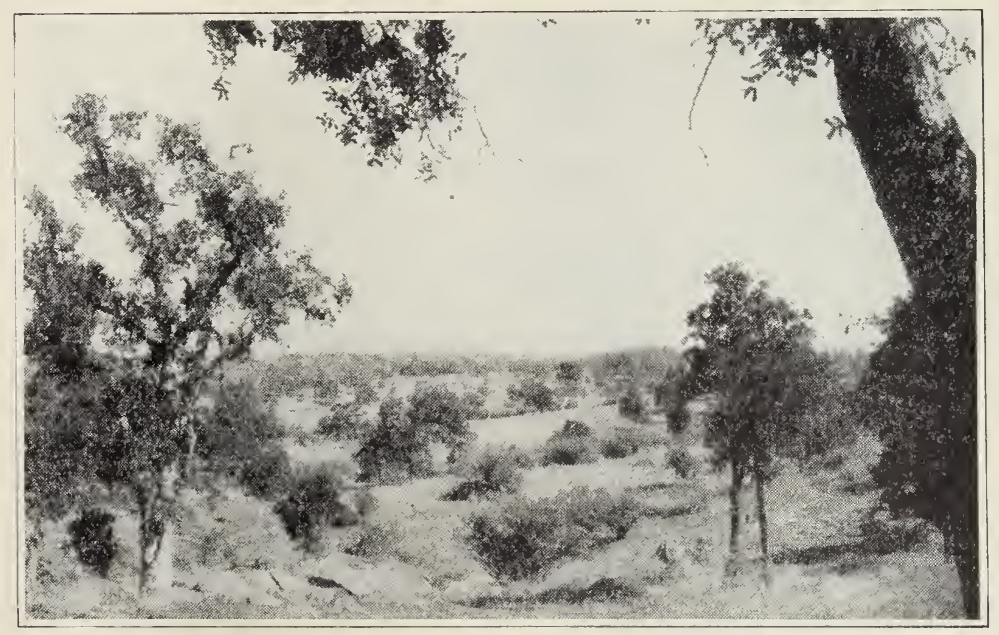

Foothill Range of the San Joaquin Valley

\section{BULLETIN 627}

March, 1939 


\section{CONTENTS}

PAGE

Review of literature . . . . . . . . . . . . . . . . . . 4

The San Joaquin Experimental Range. . . . . . . . . . . . . . . . . . . 8

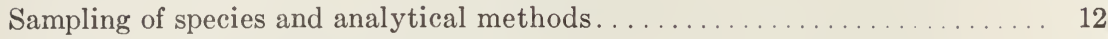

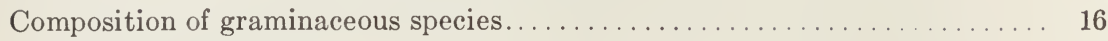

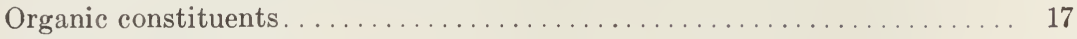

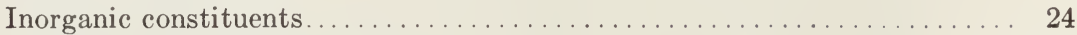

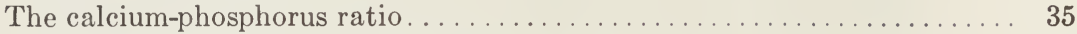

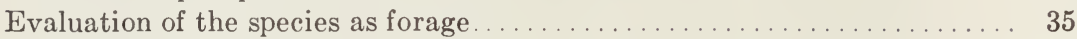

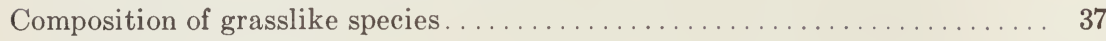

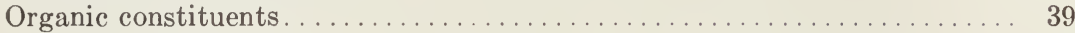

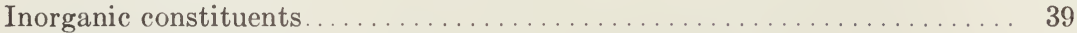

Evaluation of the species as forage ..................... 40

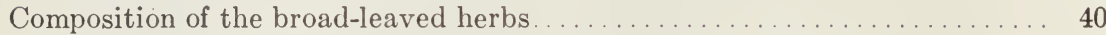

Organic constituents........................... 40

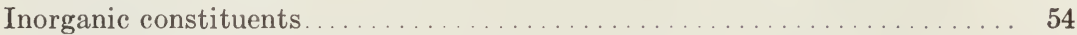

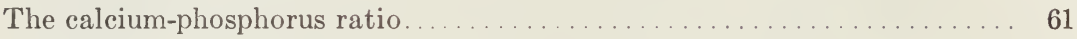

Evaluation of the species. . . . . . . . . . . . . . . . . . . . . 61

Composition of browse from shrubs and trees..................... 64

Half-shrubs........................................ 64

Nondeciduous species. . . . . . . . . . . . . . . . . . . . . . . . 72

The calcium-phosphorus ratio . . . . . . . . . . . . . . . . . 73

Evaluation of the species.............................. 74

Comparative levels of constituents in the six plant groups . . . . . . . . . 75

Application to range management ... . . . . . . . . . . . . . . . . . . . 81

Comparative forage values of the different growth stages . . . . . . . . 82

Rôle of weeds in a range community . . . . . . . . . . . . . . . . . . 84

Soils in relation to plant types and forage utilization. . . . . . . . . . 85

Criteria for judging the value of a forage plant . . . . . . . . . . . . 87

Shortening of growing season as affecting nutritive values........... 87

Chemical values and grazing capacity ...................... 88

Summary . . . . . . . . . . . . . . . . . . . . . . . . . . . . . 89

Acknowledgments. . . . . . . . . . . . . . . . . . . . . . . . . 91

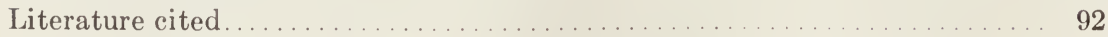




\title{
COMPOSITION OF COMMON CALIFORNIA FOOTHILL PLANTS AS A FACTOR IN RANGE MANAGEMENT ${ }^{1,2}$
}

\author{
AARON GORDON ${ }^{3}$ AND ARTHUR W. SAMPSON
}

THIS BULLETIN reports a study of chemical characteristics of certain foothill range plants commonly found in the interior valleys and on the coastal strip of California. Information obtained from such investigations should point the way to a more scientific approach to range revegetation and maintenance, and to a more accurate evaluation of the carrying capacity of the range.

In half a century of grazing by domestic livestock conspicuous changes have taken place in the plant population of this vast grass-woodland area. In many instances the carrying capacity has declined sharply, and a portion of the top soil has been removed. Evidence points to the fact that a substantial proportion of the original perennial graminaceous species has been replaced by annual exotic grasses and other herbs of southern Europe; this accounts for the inclusion of many such species in this study. So conspicuous has been this transformation that future grazing management plans must be focused largely upon this relatively early-maturing vegetation.

Although various grazing systems have been employed on some of these ranges with a view to improving the forage crop, uniformly satisfactory results in revegetation have not been obtained. Better understanding of the plant-nutrition problem is obviously basic to the improvement and maintenance of the forage cover. To understand the continuous transformations in the range-forage complex one must recognize the changes peculiar to the life cycle of individual species and the departures from these changes caused by the various limiting factors, including different degrees and character of pasture utilization.

The study was undertaken in 1935, on the San Joaquin Experimental Range of the United States Forest Service, a branch station of the California Forest and Range Experiment Station located near O'Neals.

\footnotetext{
${ }^{1}$ Received for publication June 19, 1938.

${ }^{2}$ Results of a coöperative investigation conducted by the California Forest and Range Experiment Station of the United States Forest Service, United States Department of Agriculture, and the California Agricultural Experiment Station.

Acknowledgment is also made to the Works Progress Administration for assistance rendered through its Official Project No. 465-03-3-630, Unit B-12.

${ }^{3}$ Associate Plant Ecologist, California Forest and Range Experiment Station, United States Forest Service.

${ }^{4}$ Associate Professor of Forestry and Plant Ecologist in the Experiment Station.
} 
The results are reported under the following general headings: (1) composition of the chief grass species composing the different subtypes ; (2) composition of the grasslike species ; (3) composition of the broadleaved herbs, shrubs, and arborescents ; 4 ) chemical characteristics and phylogenetic relations; (5) habitat and seasonal influences on composition; and (6) application of the results to range management.

\section{REVIEW OF LITERATURE}

It is common knowledge that the characteristic chemical composition of a species is measurably influenced by the habitat. Some investigators have also reported that the chemical levels of pasture plants vary from the earliest inception of growth to maturity.

It is fairly well established that the acidity of a soil is an important factor in rendering nutrients available to vegetation. Davis, Hoagland, and Lipman $(9)^{5}$ concluded that absorption of ions is influenced by the amount of carbon dioxide liberated by the roots. Pierre and Pohlman (39), using corn, sorghum, and sudan grass, found that differences in soil acidity from $\mathrm{pH}$ values of 4.60 to 6.60 do not affect the concentration of calcium and phosphorus in the sap of these three species. Kauter (28) found that the percentages of phosphorus, calcium, and potassium in the ash of hay increases with higher pII soil values. This he states is due to dominance of species high in these constituents in soils of lower hydrogen ion concentration. Hoagland (24), working with barley in water cultures, reported that the values of phosphorus, and less conspicuously of calcium, decrease with higher pH. Truninger and Grunigen (48) found no relation between the soil reaction in $\mathrm{pH}$ ranging between 4.5 and 8.0 and the content of phosphoric acid, potassium, and calcium in forage.

The addition of soil fertilizers generally appears to affect plant composition. Hissink (23) concluded that while the proportions of mineral constituents in the plant depend primarily on the species concerned, they are also affected by the minerals present in the soil. Cooper (5) reported that the ash constituents of pasture grasses studied are largely determined by the amounts of the various constituents available in the soil. He found that plant nitrogen and ash decrease as the soils become depleted. Jacob (27) found that addition of potassium to the soil increases the potassium content of the forage in many cases, but reduces the nitrogen and lime contents. Mortimer and Ahlgren (36), in studies with Kentucky bluegrass, reported that fertilization with nitrogen decreases the calcium and phosphorus content of this species, whereas addition to

\footnotetext{
${ }^{5}$ Italic numbers in parentheses refer to "Literature Cited" at the end of this bul-
} letin. 
the soil of phosphorus and potassium increases the nitrogen content of the herbage. They also stated that phosphate fertilization increases this constituent of the grass. Truninger and Grunigen (48) found a reduction of lime content in the plant when excessive amounts of potassium were added to the soil. Daniel and Iarper (8), in studying the composition of Andropogon furcatus, concluded that the study of a single nutrient element in the soil will not give a reliable indication of the amount of that element found in the plant.

That drought influences the composition of forage has been pointed out by various workers. Ferguson (12) states that in forage there is a decrease of calcium and phosphorus during a period of drought. Woodman, Norman, and French (52), as well as others (29), found that the most conspicuous effects of drought are: a decided decline in the percentage of protein; a slight increase in the percentage of nitrogen-free extractives and crude fiber; an abrupt rise in the percentage of calcium, accompanied by a decline in the percentage of phosphorus; and a pronounced reduction in moisture content with a premature onset of lignification. Franklin (14) reported a fairly close relation between variation in the mineral content of pasture forage and certain meteorological data. Watkins (50) found that, in range grasses of the Southwest, phosphorus is more commonly deficient than calcium.

In various stages of plant development, movement of elements takes place from one plant organ to another, and from the roots to the soil. Thus Burd (3) reported an orderly increase in nitrogen and potassium in barley during rapid growth, followed by losses at the time of heading. Murneek (37) found that tomato plants absorb the greatest quantities of nutrients and synthesize the largest amounts of organic substances when fertilization of the flowers was permitted, but when the fruit was not allowed to develop. Murneek (38) later stated that decline in vegetative growth, which is associated with the reproductive period, is accounted for by the withdrawal of nitrogenous products from the leaves. Austin (1,2), studying the soybean, found that carbohydrates accumulate in deflorated plants, but that the intake of hydrogen ion and minerals is simultaneously curtailed. Richardson, Trumble, and Shapter (40), working under controlled conditions with the perennial, Phalaris tuberosa, reported that, at plant maturity, nitrogen and phosphorus descend to the basal portion of the stem and to the roots, but a substantial portion of the total potash of the plant may diffuse from the roots into the soil.

The different parts of the plant may vary in composition. In the study of forest trees Seiden (45) reported that the ash content is lowest in the leaves of the older branches nearer the ground. In a more comprehensive 
study McHargue and Roy (34), working with 23 species of deciduous trees, found that the young foliar organs have the highest percentage of phosphorus, potassium, and nitrogen, whereas the mature foliage contains the highest percentage of ash, silicon, and calcium. Sampson and Samisch (44), working with Quercus Gambelii and Q. Kelloggii, reported high content of crude protein and crude fiber in the young leaves, but as the foliage expands the amount of these constituents per unit area decreases. Stapledon, Fagan, Evans, and Milton (47) reported that in Italian rye grass, the young leaves, and especially the leaf sheaths, are nearly twice as rich in protein as the stem. Silica-free ash is also higher in the leaves.

Conspicuous changes in plant composition take place as the season advances. Various investigators $(10,25,31,40)$ have found that with advancing maturity of forage plants the crude protein content decreases and the crude fiber and nitrogen-free extracts increase. Hart, Guilbert, and Goss (22) found that the dry matter in the forage varies from high protein content in early growth stages to that of poor roughage when the herbage has dried. Bur clover, however, retains a relatively high nutritive value throughout the year, whereas the nutritiveness of most annual species is short-lived. McCreary (33) reported the highest nitrogen content in ungrazed pasture grass during the succulent stage, followed by decline to maturity. Sampson and McCarty (42), working with Stipa pulchra, found definite seasonal trends in the annual march of carbohydrates, with a decline during the period of rapid growth and a rise after the season's peak of development. Roberts (41) found that the ash content of some native perennial grasses studied increases with maturity, whereas in some exotic grasses the ash content decreases later in the season. Several other investigators $(3,40,51)$ have reported high relative amounts of certain elements, notably potassium, phosphorus, and nitrogen, during the early growth stages, followed by decrease as maturity approaches. In the study of Phalaris tuberosa, Richardson, Trumble, and Shapter (40) found the crude protein to be 33 per cent in the tillering stage, with a decline to 3.37 per cent at maturity. The levels of phosphate and potash content decrease, while the percentage of crude fiber increases continuously from the early leaf stage to maturity. Greenhill and Page (17) reported appreciable fluctuation in calcium content in grasses during the growing season, whereas phosphorus had a definite seasonal trend, falling during drought and the early summer "flush" period, and recovering after each decline. Van Itallie (49), who worked on the chemical composition of species of grasses at various stages of growth, reported that the nitrogen, fat, and mineral constituents, 
with the exception of silicic acid, decrease with advancement of the season, whereas the crude fiber content increases steadily. Fagan and Watkins (11) found that herbs and grasses decline in nutritive values with advancing maturity. Sampson and Parker (43) noted that in St. Johnswort (Hypericum perforatum) there is a rapid rise in sucrose until blossoming time, after which the amount falls off steadily.

The levels of composition during growth vary with the species. McCreary (33) found that plants of high altitudes contain more nitrogen than those growing at lower elevations, when collected in the same growth stage. Roberts (41) reported that western forage plants increase in feeding value with increasing altitude. Van Itallie (49) noted that although the trend of the constituents is similar in all grass species studied, the relative amounts in the different species vary. Thus Holcus lanatus and Alopecurus pratensis were high in ash and potassium content, while Festuca rubra and Poa pratensis were low. Du Toit, Louw, and Malan (10) found pure species, grown in the same soil and exposed to the same climatic conditions, show appreciable differences in mineral and protein contents when harvested at definite intervals. Truninger and Grunigen (48) state that the mineral content of meadow forage, within certain limits, is influenced more strongly by the botanical composition than by soil fertilization. Pure grass stands show a smaller content of phosphoric acid and lime than do clover-grass meadows. Forbes, Whittier, and Collison (13) concluded that seasonal variations in ash content depend largely upon habitat rather than on the plant species. Daniel ( 7$)$ contends that the particular plant species is much more important than either the soil or the land treatment in determining the mineral content. He found that legumes contain more calcium than grasses. In legumes there is a high calcium-phosphorus ratio, whereas in grasses this ratio is relatively low. Kauter (28) concurred with these results. Richardson and associates (40) in their investigation of the mineral content of pastures, concluded that superphosphate applied to natural pasture induces changes in botanical composition of the pasture and in plant succession. McHargue, Roy, and Pelphrey (35), found appreciable variations between species in the amounts of iron, copper, zinc, or manganese. Capen and LeClere (4), working on Alaska species, found measurable differences in the ash and sugar content in forage species.

Leaching of certain components may affect the composition of the plant. Bur clover, according to Guilbert and Mead (18), is rich in protein, and has a narrow nutritive ratio. This ratio in mature vegetation is affected by rain, which these authors report causes the soluble constituents to be leached out. Guilbert, Mead, and Jackson (19) found that the 
ingredients most susceptible to leaching from the plant are those of certain constituents of the silica-free ash, and of the nitrogen-free extract.

The degree and season of pasturing have also been shown to affect the composition of the forage. Hopper and Nesbitt (25) reported that frequent clipping tends to maintain succulence in forage, a condition associated with high crude protein and low crude fiber. Harrison (21) found that removal of top growth lessened the carbolydrate storage, and if the clipping were sufficiently severe, no carbohydrates were stored. McCarty (32) obtained similar results in his studies of Avena fatua. Graber and associates $(15,16)$ found that the storage organs of a plant clipped at maturity contain more organic material than those of a plant harvested during the growth period.

To summarize : Analytical studies of the various constituents, particularly in regard to inorganic elements, reveal that much confusion and speculation exist. The inconsistencies, even as to general trends in the mineral constituents, and often in the organic contents, leave few definite conclusions. That there is high protein content and low fiber and nitrogen-free extract in very early growth stages, followed by gradual decline in the former and increase in the latter two, with the advance of the season, has been fairly well established. The quantitative trend in the ash content, and in the essential coustituents thereof, has been little clarified. Moreover, there remains to be determined the effect of herbage removal on the physiological reaction of the plant, as measured in chemical constituents.

The divergent results reported in the literature are ample justification for undertaking the present study.

\section{THE SAN JOAQUIN EXPERIMENTAL RANGE}

The San Joaquin Experimental Range of some 4,700 acres, where the plant collections were made, appears to be fairly representative as to soils, vegetation, and climate of the foothill area of the region generally.

The soils ${ }^{6}$ of the area are nearly all residual in character, being derived from decomposition and disintegration of coarse-grained granodiorite rock. They are of sandy loam or coarse sandy loam texture. Many stones are present as outcrop and as loose stones throughout the soil profile. Bedrock occurs at a depth of a few inches to 3 feet from the surface, with an average depth of about 18 inches. These soils are low in organic matter and close to neutral in reaction. Where undisturbed, there is usually a darkened organic surface layer about 1 inch in thickness, in which abun-

\footnotetext{
${ }^{6}$ Reported through the courtesy of Dr. R. E. Storie of the Division of Soil Technology, University of California.
} 
dant grass roots are located. There is little evidence of a true subsoil. The soil material above the bedrock is of about the same texture as that of the surface but contains less organic matter and is of lighter color. Thus the residual soils classify as Visalia sandy loam, rock outcrop phase. Small alluvial areas, 100 to 200 feet in width, occur in narrow valleys. These soils are of dark brownish-gray color and also correlate with the Visalia sandy loam or Visalia loam types.

The vegetation is essentially an open oak savanna, broken here and there by clumps of brush and small arborescents, of which Ceanothus,

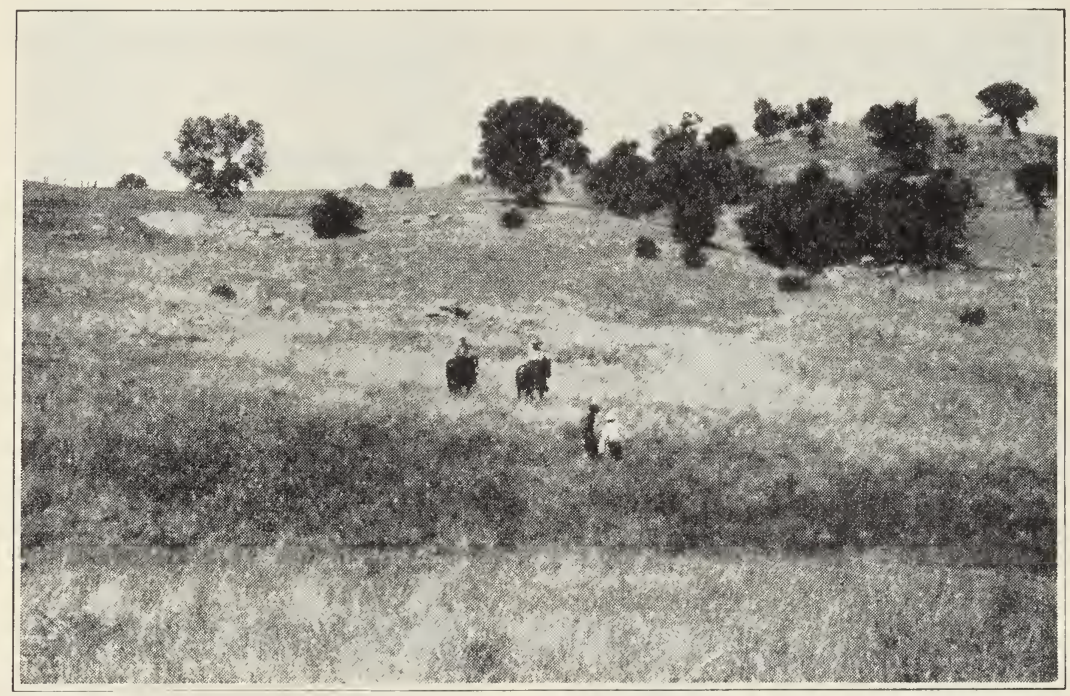

Fig. 1.-In the foreground is seen a swale which supports a dense cover of grasslike plants. Such areas contribute richly to the forage supply after the adjoining grass cover has dried.

Aesculus, Sambucus, Rhamnus, silverleaf (Lupinus), and deerweed (Lotus) are conspicuous (frontispiece and fig. 1). Quercus Douglasii is the most characteristic tree, with $Q$. Wislizenii and Pinus Sabiniana conspicuous in restricted sites. The herbaceous cover is composed largely of annual grasses, with an abundance of broad-leaved annual herbs. ${ }^{\text {? }}$

The woody plants named occur with the grass dominants throughout the range, and in an occasional restricted area they form the major vegetation. The several swales support a dense cover (60-90 per cent density) mainly of Eleocharis palustris, Juncus bufonius, and J.oxymeris (fig.

${ }^{7}$ Unpublished studies by the California Forest and Range Experiment Station reveal the fact that on 2,165 sample plots scattered at random throughout the San Joaquin Valley ranges, annuals now account for 97 per cent of the herbage, with bunch grasses and other perennials accounting for only 3 per cent. 
1). Much of this vegetation remains succulent long after the grasses of the well-drained soils have matured, when it furnishes important forage.

The various species analyses of which are reported in this bulletin are here listed to indicate further the character of the cover :

\section{Grasses and Grasslike Species ${ }^{8}$}

Avena barbata Brot. (Slender wild oats)

Bromus arenarius Labill. (Australian chess)

Bromus mollis L. (Soft chess)

Bromus rigidus Roth. (Ripgut grass)

Bromus rubens L. (Foxtail chess)

Festuca megalura Nutt. (Foxtail fescue)
Melica imperfecta* Trin. (California melic)

Poa scabrella* (Thurb.) Benth. (Pine bluegrass)

Eleocharis palustris* R. and S. (Wire grass)

Juncus bufonius L. (Toad rush)

Juncus oxymeris* Engelm. (Slenderleaved rush)

\section{Broad-Leaved Herbs ${ }^{8}$}

Amsinckia Douglasiana DC. (Buckthorn weed)

Cryptantha flaccida (Dougl.) Greene (White forget-me-not)

Erodium botrys Bertol. (Storksbill)

Erodium cicutarium L'Her. (Red-stem filaree)

Erodium moschatum L'Her. (Whitestem filaree)

Filago gallica L. (Woolly filago)

Gilia tricolor Benth. (Birdseye gilia)

Godctia amoena (Lehm.) Lilja. (Summer's darling)

Godetia quadrivulnera (Dougl.) Spach. (Spotted godetia)

Hemizonia virgata Gray (Yellow tarweed)

Hemizonia Wrightii Gray (Tarweed)

Layia pentachaeta Gray (Tidytips)

Lessingia germanorum Cham. (Lessingia)

Linanthus ciliatus (Benth.) Greene (Pink linanthus)

\section{SHrubs AND Trees}

Aesculus californica (Spach.) Nutt. (California buckeye)

Ceanothus cuneatus (Hook.) Nutt. (Wedgeleaf ceanothus)

Ceanothus divaricatus Nutt. (Whitebark soapbloom )

Lupinus albifrons Benth. (Silverleaf lupine)
Lotus americanus (Nutt.) Bisch. (Spanish clover)

Lotus strigosus (Nutt.) Greene (Hairy lotus)

Lotus subpinnatus Lag. (Fine-leaved lotus)

Lupinus Benthami Hel. (Bentham lupine)

Lupinus bicolor Lindl. (Late valley lupine)

Lupinus formosus* Greene (Wand lupine)

Navarretia viscidula Benth. (Viseid navarretia)

Plagiobothrys nothofulvus Gray (Popcorn flower)

Plagiobothrys tenellus Gray (Popcorn flower)

Silene gallica L. (Windmill pink)

Trifolium tridentatum Lindl. (Tomeat clover)

The climatic characteristics of the foothill range are typified by distinctly seasonal rainfall, by temperatures sufficiently mild to favor growth of "winter" annuals, and by long, hot, dry summers.

Rains of sufficient magnitude to initiate seed germination and the

${ }^{8}$ Species of grasses and broad-leaved herbs marked with an asterisk are of perennial growth. 
greening of bunch grasses usually come in October. A rain of about 1 inch starts vigorous plant activity. Culmination of the rainy season is generally about the last of April, but light showers are sometimes received as late as July. Cumulative rainfall records compiled by the California Forest and Range Experiment Station for the period of study (fig. 2) show the annual precipitation to vary from 22.65 inches, as in 1935-36, to 29.60 inches, in 1934-35. In 1935-36 a dry period occurred

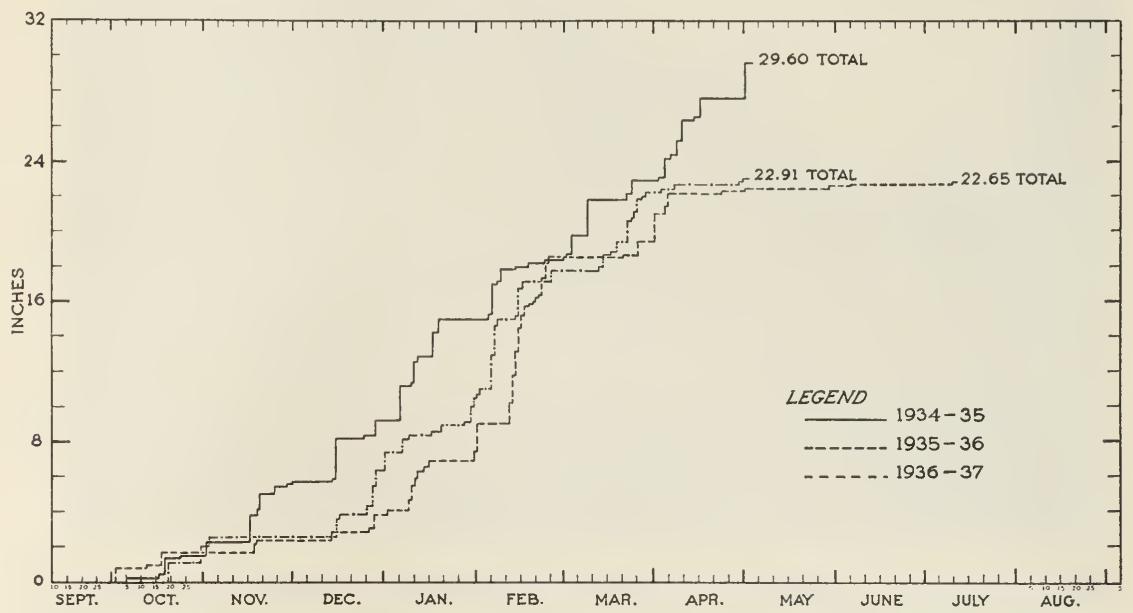

Fig. 2.-Cumulative inches of rainfall recorded on the San Joaquin Experimental Range for the seasons of 1934-35, 1935-36, and 1936-37.

after favorable early October rains. This dry period was not broken in December, hence the growth of early winter forage was below normal. In 1934-35, distribution of rainfall was highly favorable to growth from its inception to its termination. Rains that fall early in May and thereafter, promote little or no growth and may actually decrease the nutritive value of such forage as has matured. Variation in the total annual rainfall, and in its seasonal distribution, may be sufficient to influence measurably from year to year the reproductive capacity and the yield of forage.

The temperature factor, with an extreme annual range of approximately $100^{\circ}$ Fahrenheit, is limiting to growth only from about December to February (fig. 3). During this period the mean minimum temperature is little above $40^{\circ}$, with occasional periods of freezing temperatures. In January, 1937, some of the herbage was frozen to the ground, whereas in the two previous years the rate of growth was almost nil during the several weeks of cold weather. In February, with the characteristic annual rise in temperature the growth rate increases sharply. Maximum 
temperatures are reached in July and August, 2 or 3 months after the annual grasses have matured. As seen from the graphs of the mean temperatures for 1935, 1936, and 1937, there is an orderly rise and fall,

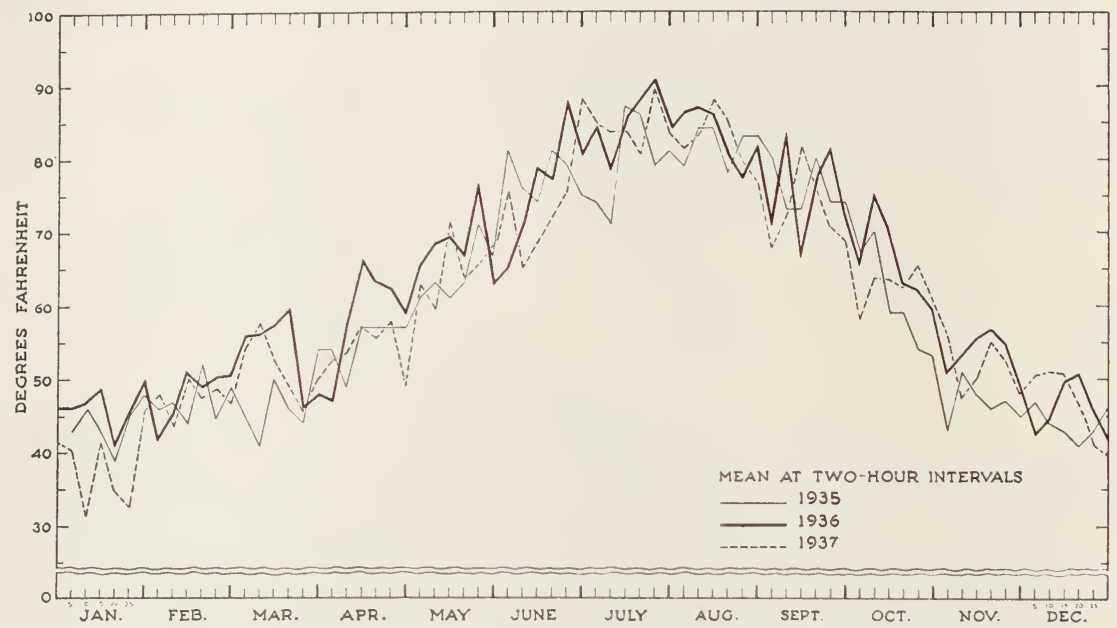

Fig. 3.-Temperatures recorded on the San Joaquin Experimental Range

for 1935,1936 , and 1937 .

respectively, in temperatures before and after the summer maxima. Between June and October the succulent regetation consists of browse, species of Lotus, and small patches of grasslike vegetation. Departures in mean temperatures are seen to be insignificant for the past two years. If snow falls at all, it usually melts soon.

\section{SAMPLING OF SPECIES AND ANALYTICAL METHODS}

Studies of range plants are complicated by the fact that the species which compose the cover are not in a uniform developmental stage at a given sampling period. In any habitat some species germinate or vegetate early; they may have virtually completed the growth cycle when latermaturing species start growing vigorously. Individuals of the same species often occur in different growth stages at a given period. Accordingly, random sampling without the recognition of the stage of development, or the collection of composite samples, has proved of little value in building up information leading to better understanding of range management. It is only through the accumulation of knowledge of the composition of individual species, taken at definite physiological stages, irrespective of chronological periods, that reliable data may be obtained.

The species studied were taken on plots characteristic of different soil 
and drainage conditions. Samples of most species were collected on a small plateau of about 6 acres (fig. 4 ). In addition, several species were grown from seed in the plant nursery of the range, which is a test plot (fig. 5) of forage species, the soil of which is uniformly deep and well

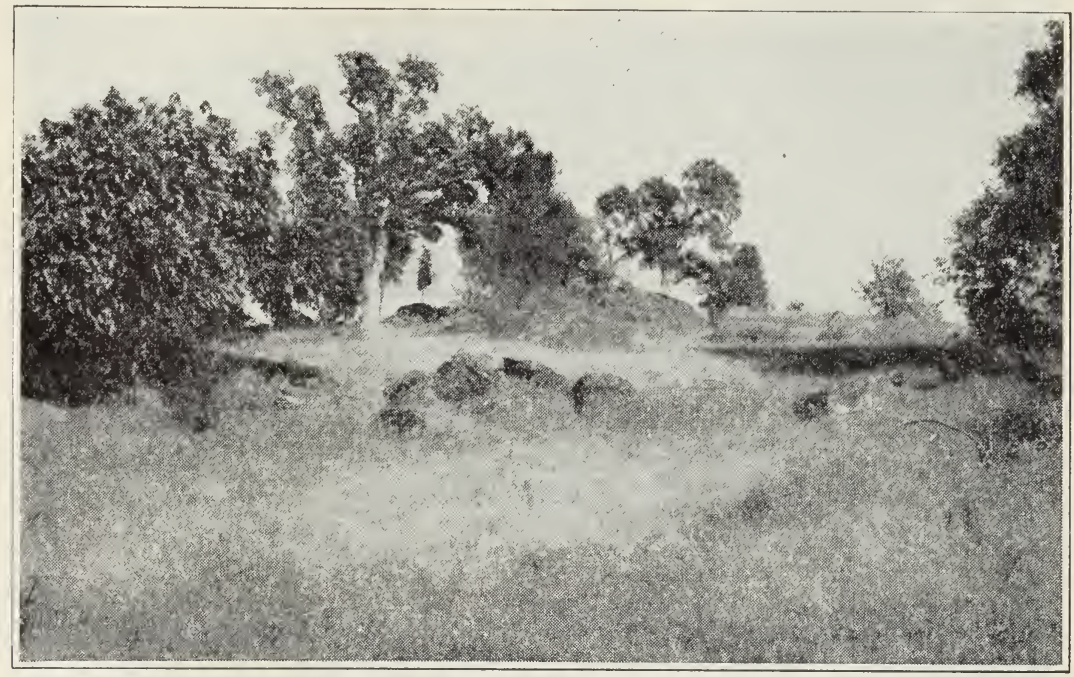

Fig. 4.-Portion of the main range area where about 70 per cent of the species studied were collected in various growth stages. The herbage, with an estimated density of 35 per cent, consists mainly of Festuca megalura, Erodium botrys, Bromus rigidus, B. mollis, and Avena barbata. The arborescents seen are Aesculus californica, Quercus Douglasii, and Q. Wislizenii.

drained. Also a few species were collected at the ranch headquarters on undisturbed soil.

Detailed record was made of the particular growth stage of each species at the time of sampling. Collections were made according to stages of plant development rather than chronological date. The composite samples for the analyses were procured from several plants collected at random and all of as nearly the same growth stage as possible. Effort was made to secure the material in the sequence here listed:

1. Early leaf stage (initial aerial growth).

2. Just before flowering.

3. Plants in full bloom.

4. When the seeds were in dough stage (endosperm plastic).

5. Plants mature, seeds cast.

6. Herbage dry and weathered.

These growth stages are presented in figures 6 and 7. 
Occasionally in the same habitat, and on the same date, two growth stages of some of the species were procured. The samples of all herbaceous species were cut with shears about 1 inch from the ground surface.

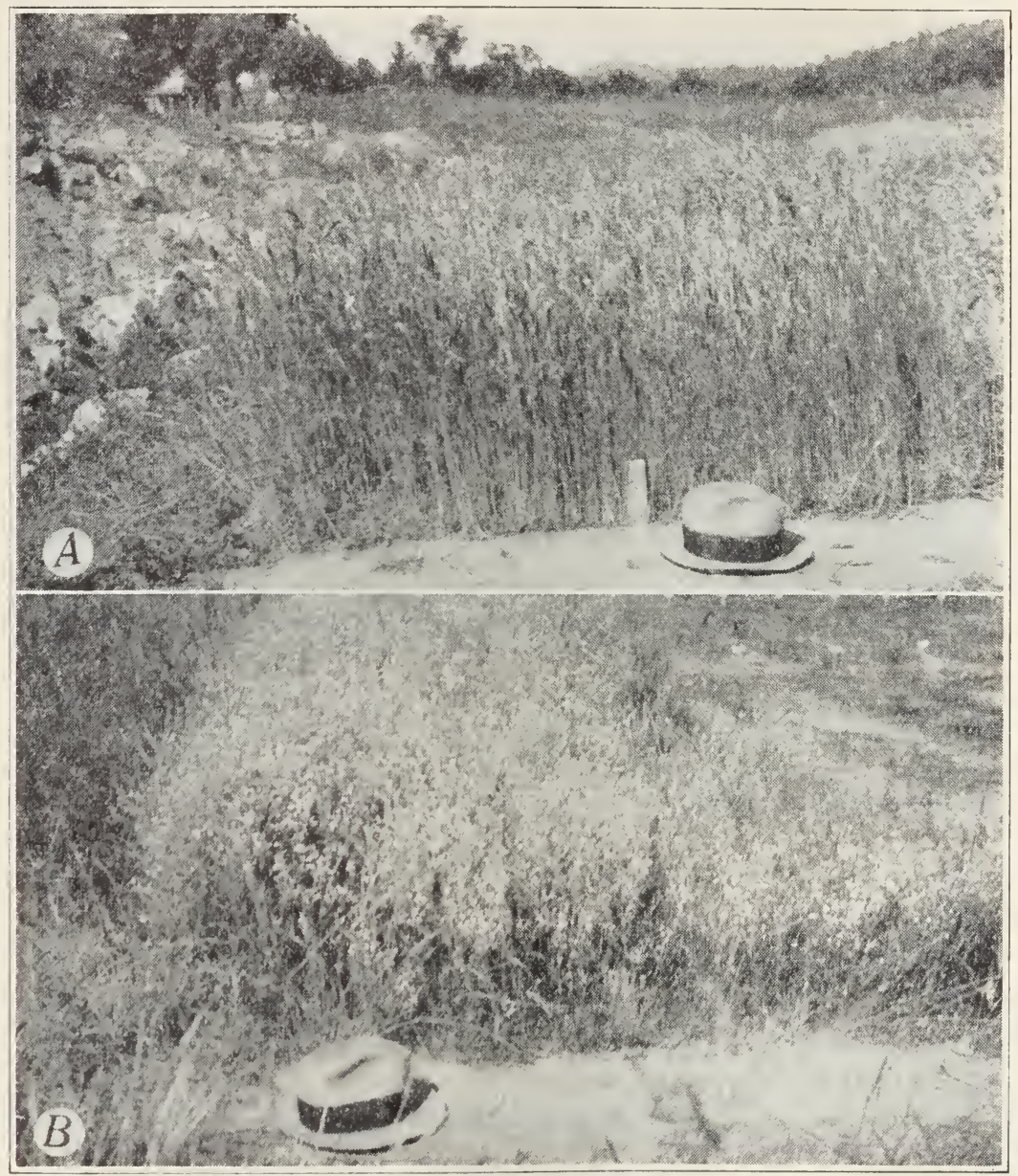

Fig. 5.-Areas $6 \times 20$ feet were seeded in the nursery to facilitate procuring samples of very young herbage and also of the more advanced growth. $A$, Bromus mollis; and $B$, Plagiobothrys tenellus.

The samples of all species of the rosette form, and the earliest collections of grasses and grasslike plants, were washed in several changes of water to remove surficial soil particles and other foreign materials. Prior to the adoption of this procedure, analyses were made of washed and of carefully wiped but unwashed samples, and these analyses revealed that washing did not influence the chemical composition of the succulent ma- 
terial. Samples of trees and shrubs consisted chiefly of the foliage, which was stripped off by hand; but in several species flowers, fruit, and current branch growth were collected and analyzed separately. At the time of collecting, additional specimens were placed in a plant press for subsequent observation and verification of the particular growth stage which

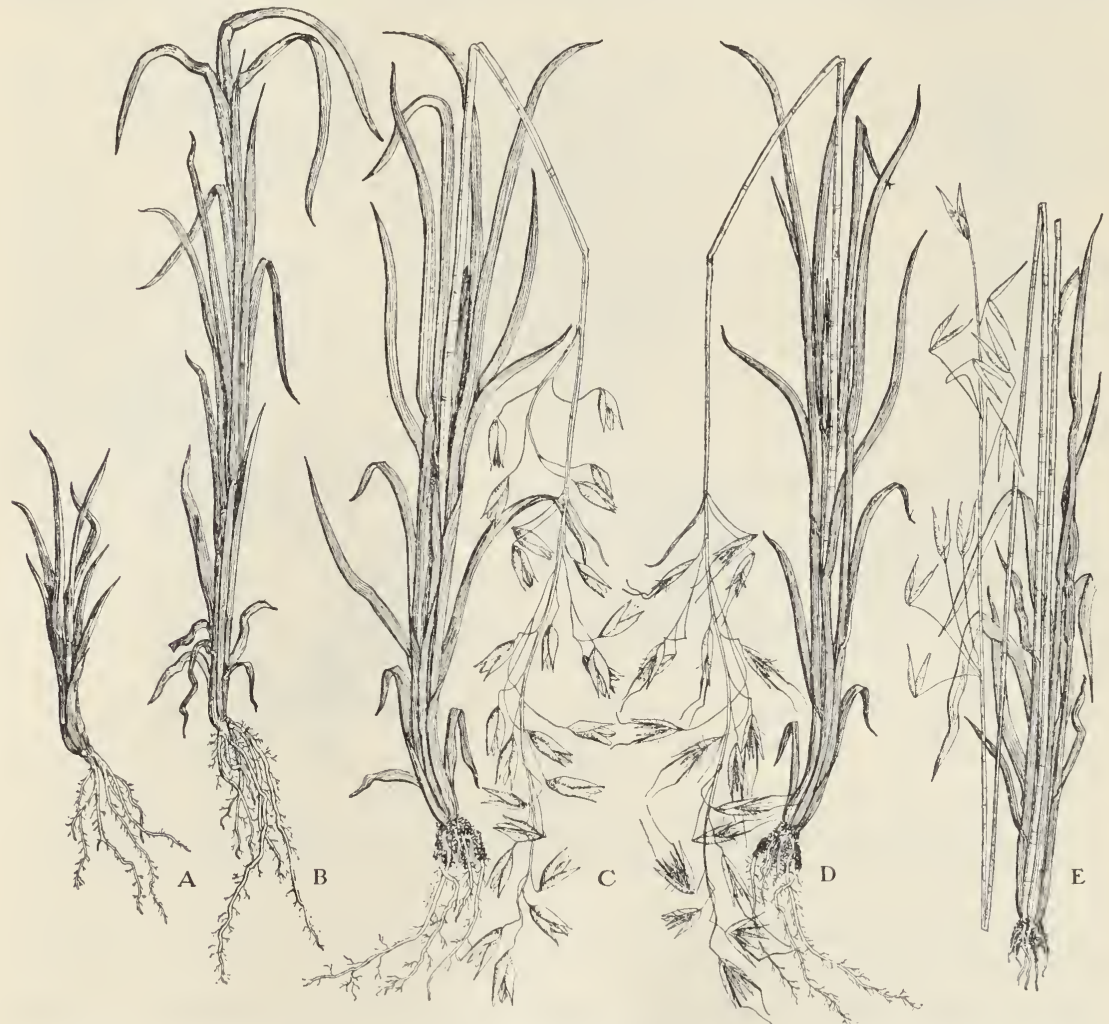

Fig. 6.-Avena barbata showing five of the growth stages from which the samples were collected. $A$, Early leaf stage; $B$, just before flowering; $C$, full bloom; $D$, seeds in dough stage; $E$, herbage weathered and the seeds cast.

each sample represented; these specimens served to classify the data with respect to march in composition. Several of the pressed specimens were sketched to scale for permanent record.

The fresh weights of the samples were recorded immediately following the collection, after which the material was dried in an electric oven, with circulating air, at a temperature of $70^{\circ} \mathrm{C}$. When thoroughly dry, the samples were finely ground, bottled, and tightly stoppered. After the analyses of the samples were completed an aliquot part of each sample was dried at $100^{\circ} \mathrm{C}$ to constant weight ; the analytical data were then expressed on this moisture-free basis. 
In the determination for nitrogen, calcium, ash, and moisture, Official and Tentative Methods of Analysis of the Association of Agricultural Chemists ${ }^{9}$ was followed. Phosphorus was determined colorimetrically, as described by Kuttner and Cohen (30). The only modification made was that the sample was ignited with $\mathrm{MgO}$, dissolved in strong $\mathrm{HCl}$, and after
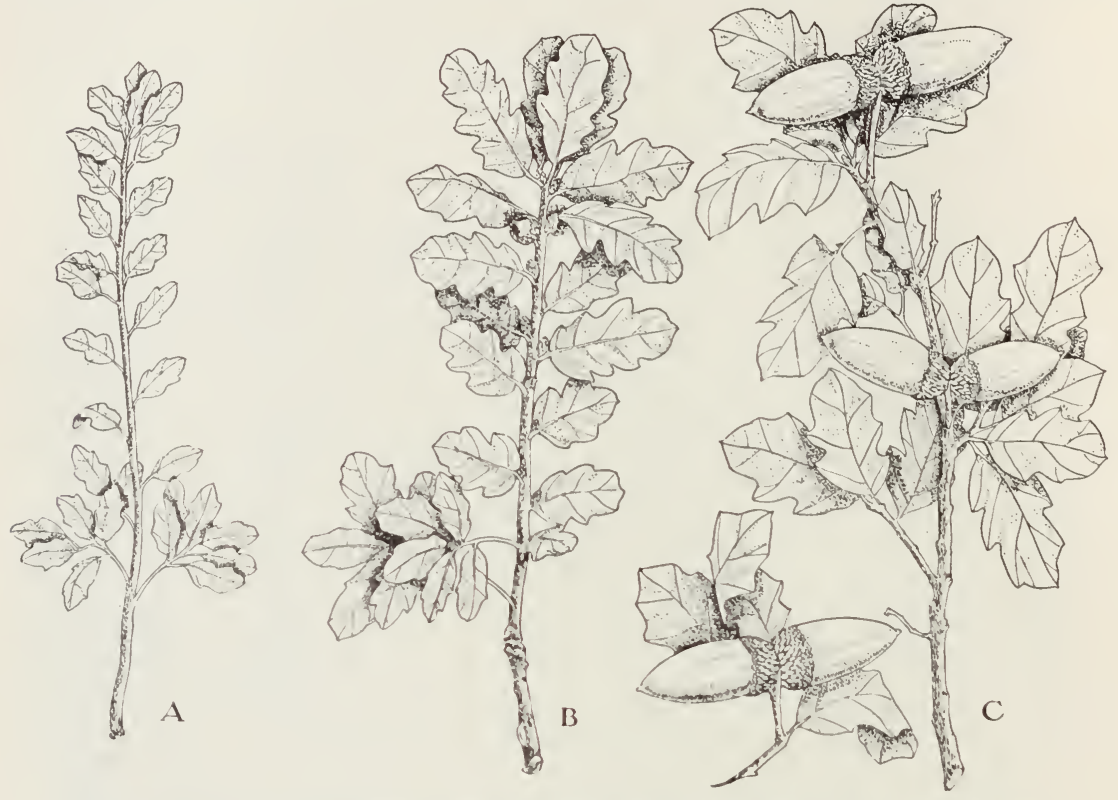

Fig. 7.-Quercus Douglasii showing the growth stage when the samples were collected. $A$, Early leaf stage; $B$, full bloom; $C$, fruit mature but none cast.

rinsing the solution into a 100 -ce volumetric flask, it was brought just to neutral, as indicated by litmus, before the sulfuric acid and other reagents were added. Crude fiber was determined by the method described by Sharrer and Kurschmer (46). Silica was determined by treating the ignited residue of the sample with concentrated $\mathrm{HCl}$ and 60 per cent $\mathrm{HClO}_{4}$ and igniting the residue after digesting on the steam bath, and then filtering.

\section{COMPOSITION OF GRAMINACEOUS SPECIES}

Table 1 gives the location where the samples of graminaceous species were collected, the date of sampling, the stages of growth, and the results of analyses. The first column, showing the respective growth stages, is arranged in sequences from the early leaf stage to the time of full ma-

\footnotetext{
Association of Official A gricultural Chemists. Official and tentative methods of analysis of the Association of Agricultural Chemists. Association of Official Agricultural Chemists. Washington, D. C. 3d ed. 593 p. 1930.
} 
turity, for the respective years and locations. Where two samples representing a specific growth stage are given, the slightly younger sample is presented first. Although definite growth stages are given for each sample, the fact must not be overlooked that growth is a continuous process, hence the stages designated are necessarily somewhat approximate.

There is a continuous and rather orderly change in composition of all constituents here reported, from the earliest appearance of leaf blades to plant maturity. The content of most constituents, with the exception of crude fiber, is highest in early growth and declines rather uniformly, although at a different rate in the various stages, reaching the lowest point in most species at full maturity.

For each of the three years of study there is an impressive consistency in the composition of all the grass species for any given growth stage. It is well known that the character of the soil medium may affect absorption, and therefore the composition of the plant. However, under the range conditions concerned, the soil solution is evidently in an approximate state of equilibrium and does not appear measurably to affect the composition of the supporting vegetation from year to year.

Organic Constituents.-The uniformity in composition with respect to organic constituents at any given growth stage is illustrated in figures 8 and 9, which give, for three years, the march in composition of the protein and fiber of the annual species, Avena barbata, and the perennial, Poa scabrella. In both these constituents by far the most precipitous change occurs from the early leaf period to the time that the plant is in late bloom, designated as $A B$ in figures 8 and 9 . From the time of full bloom to maturity, designated as $B C$ in these figures, the rate of change is slight and inconspicuous, though the trend is in the same general direction. When the plant first reaches maturity, until it is thoroughly weathered in the late summer, designated as $C D$, there is little change in the contents of crude protein and crude fiber. This fact is impressive in view of the lapse of time between procuring samples of the recently matured plant, indicated by $C$ in the figures, and the older, bleached sample, designated by $D$. Obviously this behavior applies only to those species whose seeds are not scattered between collections of the samples. In Bromus mollis, whose seeds are mostly retained long after maturity, the relatively large changes in protein content after the herbage has dried, are accounted for by the proportion of the seeds retained. On June 13, 1936, and on June 14, 1937, for example, when only a few of the seeds had been cast in the field samples, the percentages of protein were 6.10 and 6.25, respectively. On September 10, 1936, when most of the seeds had been cast, the percentage of protein was 3.76 . 


\begin{tabular}{|c|c|c|c|c|c|c|c|}
\hline \multirow{2}{*}{\multicolumn{2}{|c|}{ 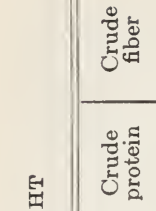 }} & & 曈 & 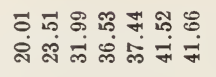 & 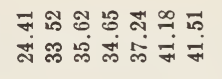 & 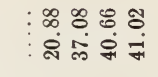 & 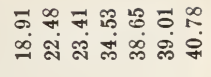 \\
\hline & & & సุ. & 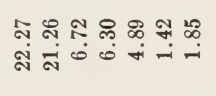 & 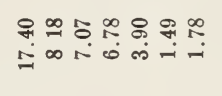 & 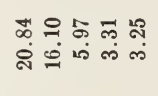 & 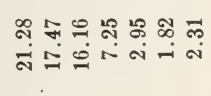 \\
\hline 3 & 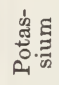 & & ลุ & 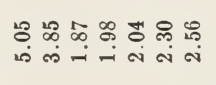 & 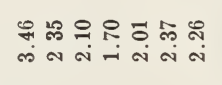 & 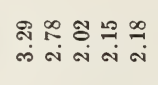 & 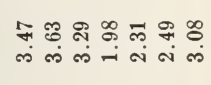 \\
\hline b & 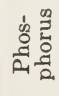 & & $\stackrel{\mathscr{g}}{\rightleftarrows}$ & 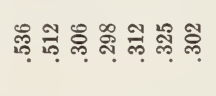 & 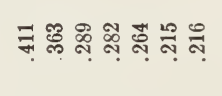 & 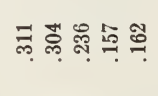 & 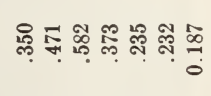 \\
\hline 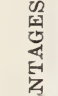 & हुँच & & $\begin{array}{c}\stackrel{0}{\infty} \\
\substack{0 \\
0}\end{array}$ & 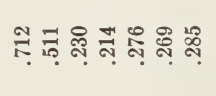 & 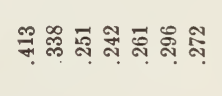 & 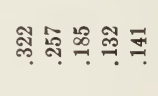 & 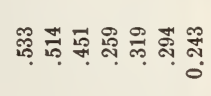 \\
\hline 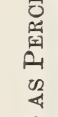 & 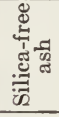 & & $\stackrel{8}{0}$ & : 东号 & 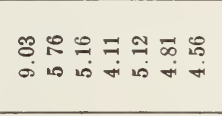 & 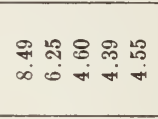 & 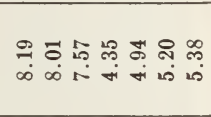 \\
\hline $\begin{array}{l}\text { 舅 } \\
0 \\
01 \\
\text { 鼠 }\end{array}$ & 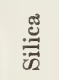 & & สุ & 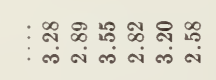 & 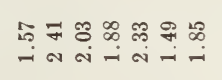 & 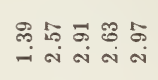 & 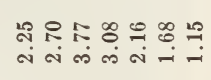 \\
\hline 至 & 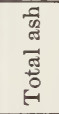 & 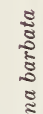 & $\stackrel{\text { I্ }}{i}$ & 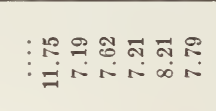 & 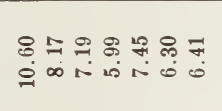 & $\begin{array}{l}\infty \\
\infty \\
\infty \\
\infty \\
\infty\end{array}$ & 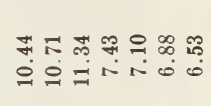 \\
\hline 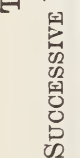 & & & $\begin{array}{l}\frac{0}{0} \\
\frac{0}{0} \\
\stackrel{0}{0}\end{array}$ & 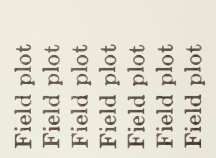 & 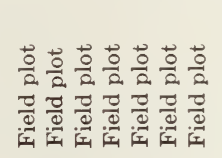 & 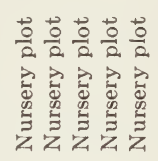 & 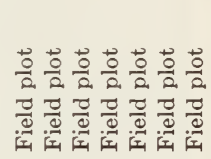 \\
\hline 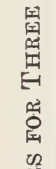 & 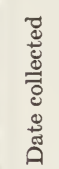 & & 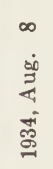 & 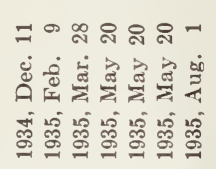 & 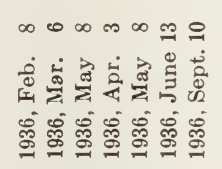 & 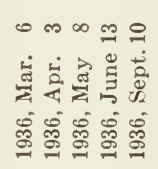 & 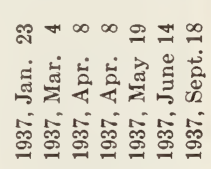 \\
\hline 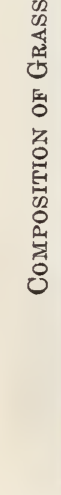 & 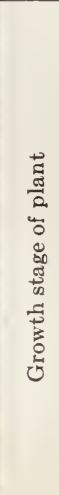 & & 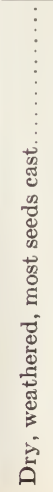 & 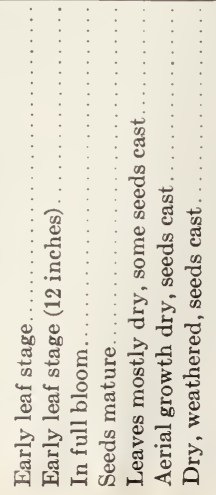 & 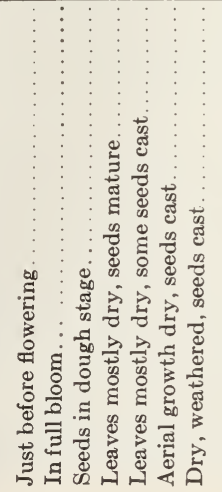 & 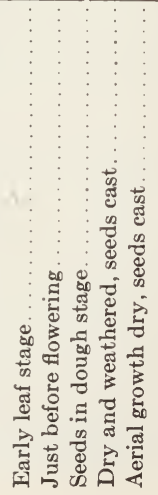 & 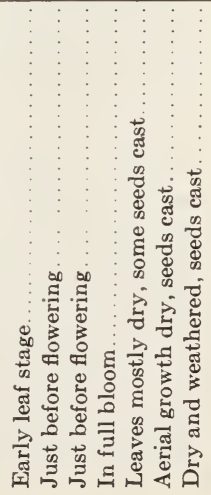 \\
\hline
\end{tabular}




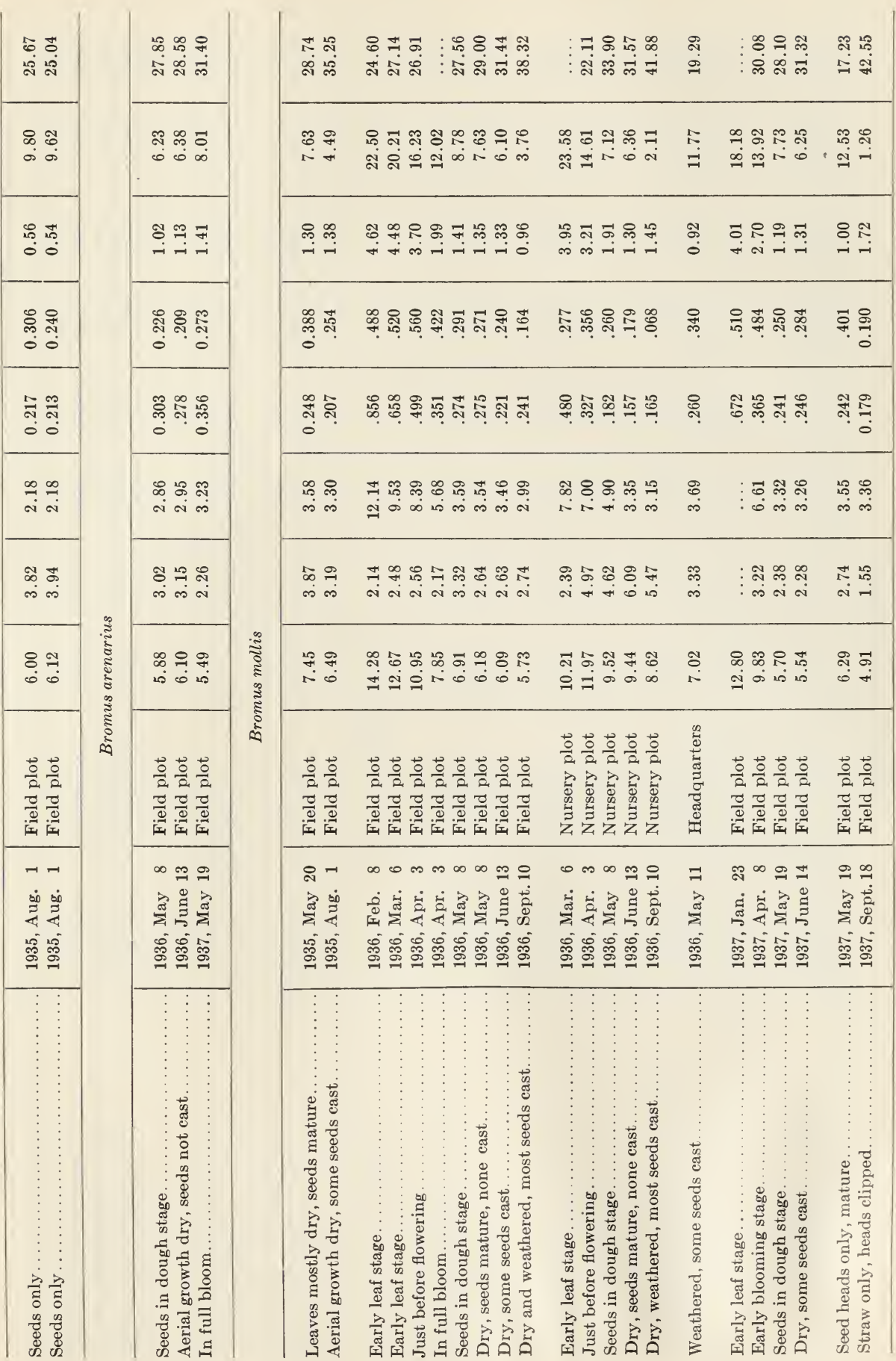




\begin{tabular}{|c|c|c|c|c|c|c|c|c|c|}
\hline 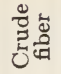 & \multirow{11}{*}{ 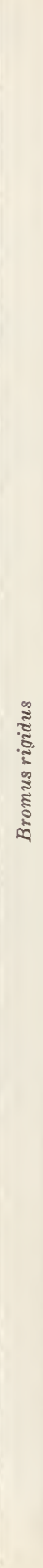 } & 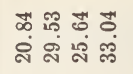 & 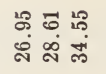 & 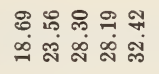 & \& & 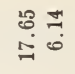 & \multirow{11}{*}{ 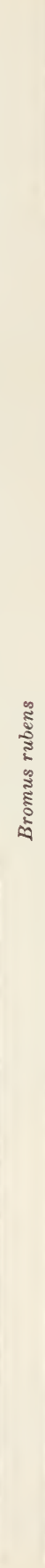 } & 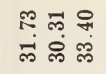 & 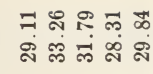 \\
\hline 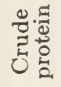 & & 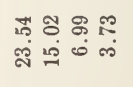 & 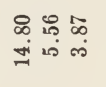 & 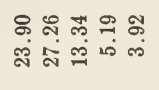 & 岗 & 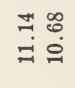 & & 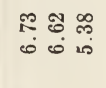 & 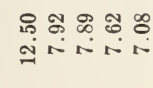 \\
\hline 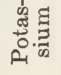 & & 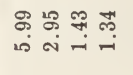 & 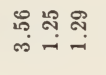 & 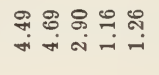 & $\begin{array}{l}\stackrel{\infty}{\circ} \\
\text { is }\end{array}$ & $\begin{array}{ll}\infty & 0 \\
\infty & 0 \\
0 & 0\end{array}$ & & 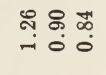 & 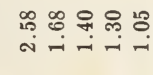 \\
\hline 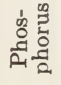 & & 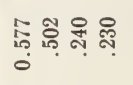 & 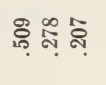 & 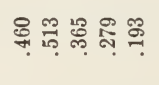 & 尽 & 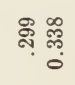 & & 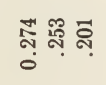 & 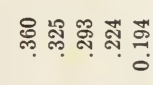 \\
\hline 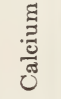 & & 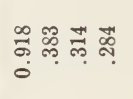 & 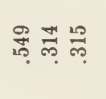 & 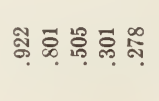 & $\stackrel{0}{7}$ & ลี่ & & 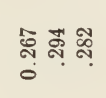 & 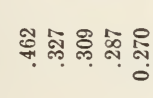 \\
\hline 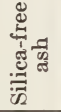 & & 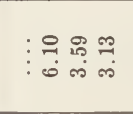 & 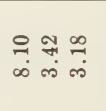 & 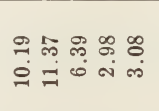 & 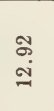 & $\begin{array}{l}\overline{5}: 8 \\
\text { i d }\end{array}$ & & 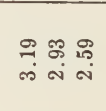 & 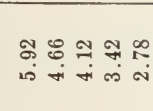 \\
\hline 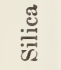 & & 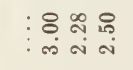 & 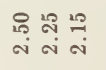 & 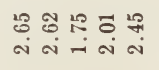 & $\stackrel{\infty}{\infty}$ & 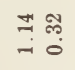 & & 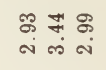 & 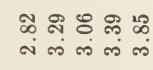 \\
\hline 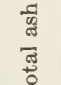 & & 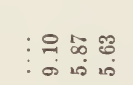 & 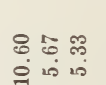 & 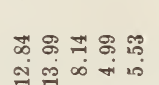 & $\begin{array}{l}\infty \\
\infty \\
+ \\
\end{array}$ & 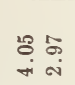 & & 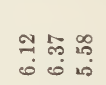 & 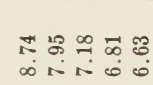 \\
\hline & & 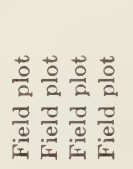 & 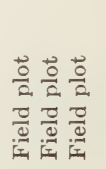 & 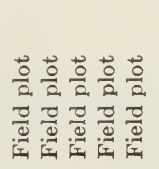 & 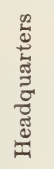 & 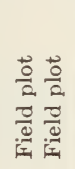 & & 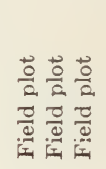 & 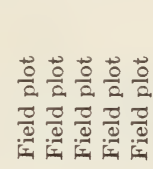 \\
\hline 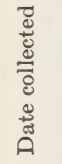 & & 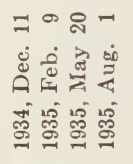 & 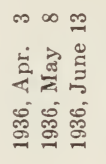 & 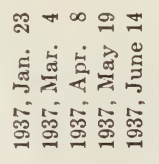 & 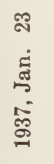 & 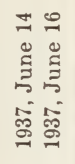 & & 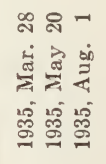 & 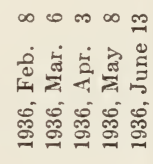 \\
\hline 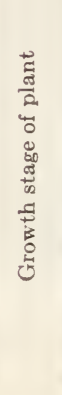 & & 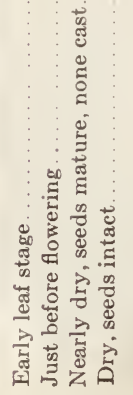 & 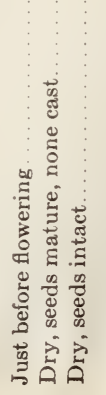 & 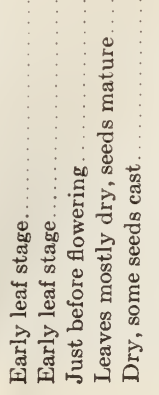 & 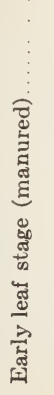 & 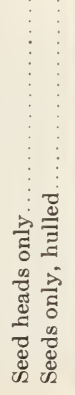 & & 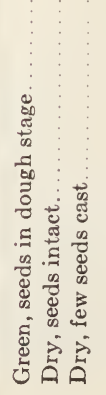 & 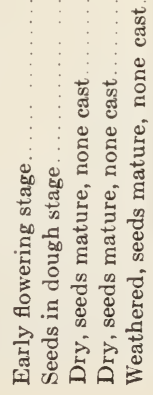 \\
\hline
\end{tabular}




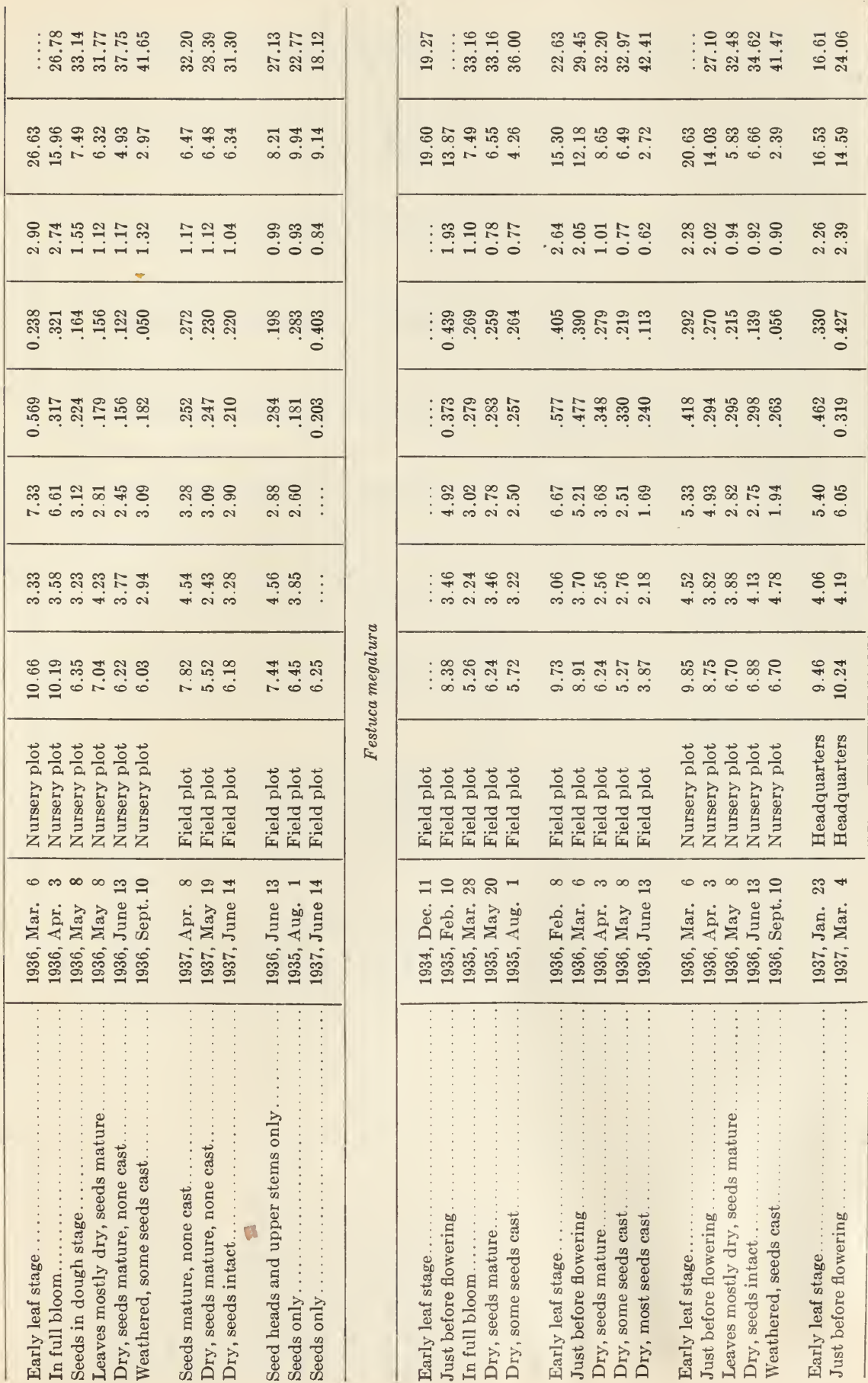




\begin{tabular}{|c|c|c|c|c|c|c|c|c|}
\hline 苞苛 & \multirow{11}{*}{ 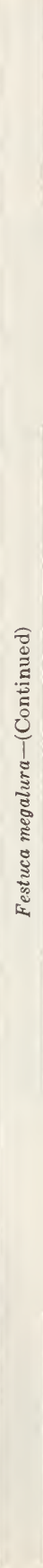 } & 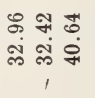 & 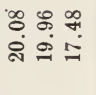 & \multirow{11}{*}{ 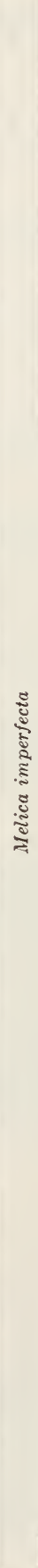 } & 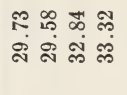 & 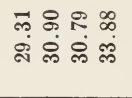 & 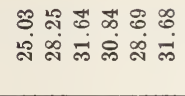 & 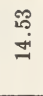 \\
\hline 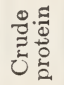 & & 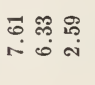 & 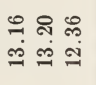 & & 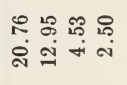 & 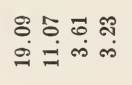 & 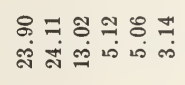 & $\begin{array}{l}\mathscr{L} \\
\stackrel{\leftrightarrow}{+}\end{array}$ \\
\hline के & & 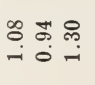 & 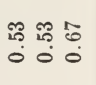 & & 怘 & ס્ర & 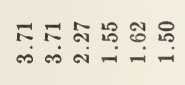 & $\begin{array}{l}\infty \\
\infty \\
0\end{array}$ \\
\hline 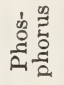 & & 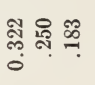 & 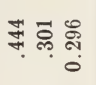 & & 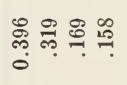 & 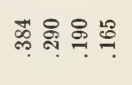 & 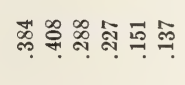 & $\underset{\substack{m \\
0}}{0}$ \\
\hline ฮี & & 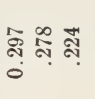 & 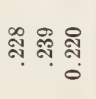 & & 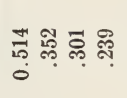 & 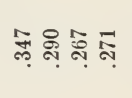 & 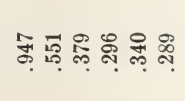 & $\stackrel{8}{:}$ \\
\hline 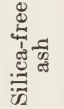 & & 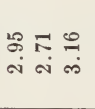 & 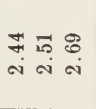 & & 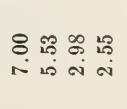 & 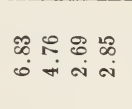 & 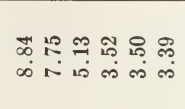 & $\underset{\substack{i \\
\text { in }}}{2}$ \\
\hline 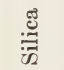 & & $\begin{array}{l}\text { \&े क्ष त } \\
\text { in in in }\end{array}$ & 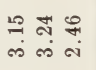 & & 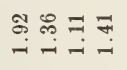 & \& & 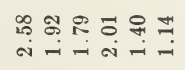 & $\stackrel{\wp}{\infty}$ \\
\hline 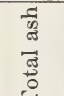 & & 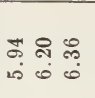 & 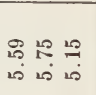 & & 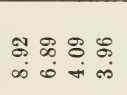 & 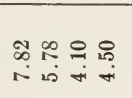 & 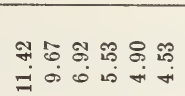 & $\stackrel{\Re}{?}$ \\
\hline 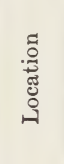 & & 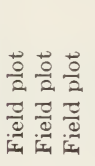 & 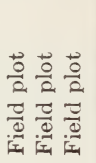 & & 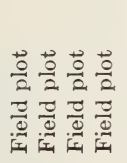 & 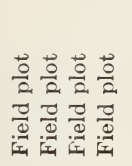 & 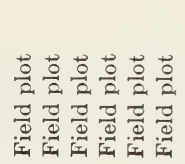 & $\frac{\overrightarrow{0}}{\frac{0}{2}}$ \\
\hline 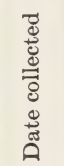 & & 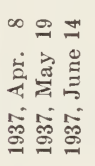 & 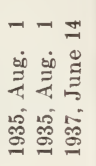 & & 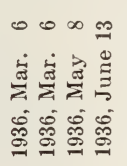 & 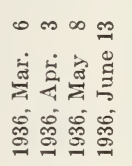 & 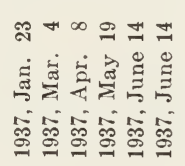 & 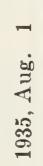 \\
\hline 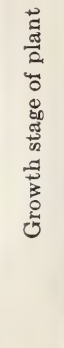 & & 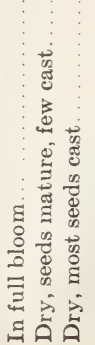 & 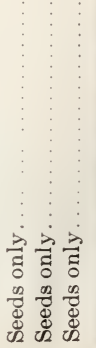 & & 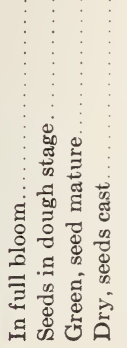 & 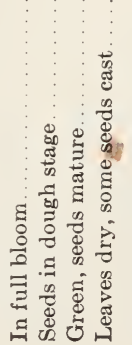 & 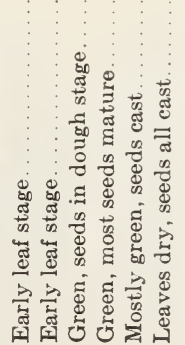 & 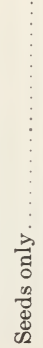 \\
\hline
\end{tabular}


ஜ ลั

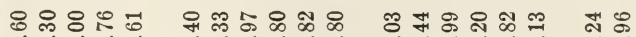

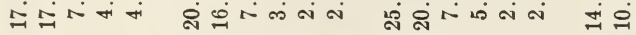

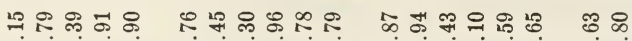

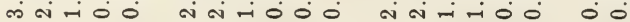

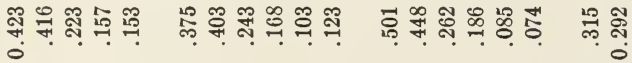

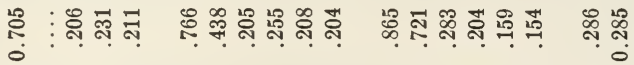

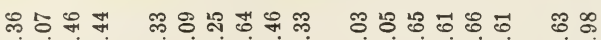

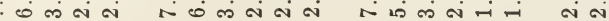

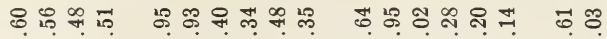

- $\rightarrow$ i

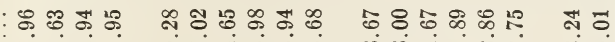

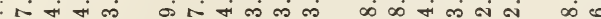

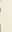

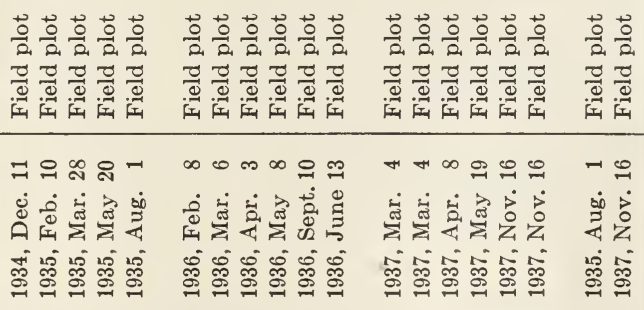

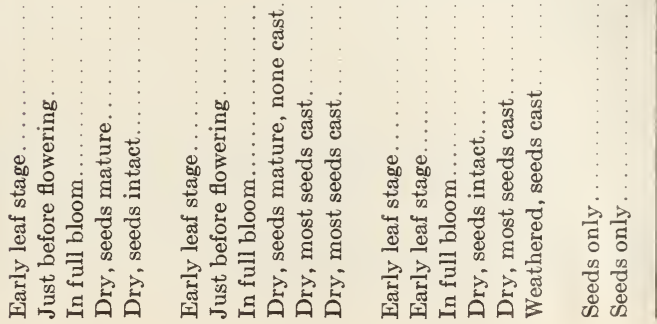


Where change in composition of various stages is discussed in this report the composition of the earliest leaf stage is taken as unity, or 100 per cent. On this basis, calculations from table 1 bring out the fact that the crude protein content in Bromus mollis and in Avena barbata, from the earliest leaf stage to maturity, when most or all of the seeds are cast, declines 83 per cent in 1936 and 89 per cent in 1937, respectively. In Melica imperfecta, a perennial species, the decline is 87 per cent for the corresponding growth stages. In contrast, the crude protein levels at the early growth stage for the various grass species do not differ greatly. Calculations show the difference between the highest and lowest protein content for all grasses reported, when in the early leaf stage, to be 44 per cent, whereas there is a difference of 94 per cent in $A$. barbata for the entire growth cycle, as in 1935.

The crude fiber, as found by many workers, is lowest in the early growth of the plant and highest at the time of full maturity. In Avena barbata, in 1937, the crude fiber content increases 115.6 per cent from the early leaf stage to full maturity; the other species investigated show similar increases for corresponding growth stages. In contrast to the wide seasonal variation within a species there is small difference in this constituent among the species studied for a given growth stage.

The variations in the level of crude fiber in Avena barbata at five growth stages for three successive years are shown in figure 10 . The crude protein content is included in this figure for purposes of comparison. The averaged composition of these two organic constituents at the early leaf stage is shown in figure 11 for six grasses. Comparison of figures 10 and 11 shows that the differences in the percentages of crude fiber and crude protein between the various species investigated are not so great in any one growth stage as those in a single species for the entire season of growth.

Inorganic Constituents.-Without exception the mineral content of all the grass species here reported is highest in the very young herbage. Although the decline is not so precipitous as that of crude protein, the mineral constituents decrease in most species with aging of the plant, generally reaching the lowest point when the top growth has dried.

The march of the ash content is similar to that of the potassium in Avena barbata and Poa scabrella, as shown in figures 12 and 13. The highest levels of these components occur in the very young herbage, and, like the protein content, they decline rather sharply to the late blossoming period, as shown by the segments $A B$. From the latter period of maturity, indicated by $B C$, these constituents are fairly constant. Moreover, from maturity to thorough weathering - a dry, hot period from May to 

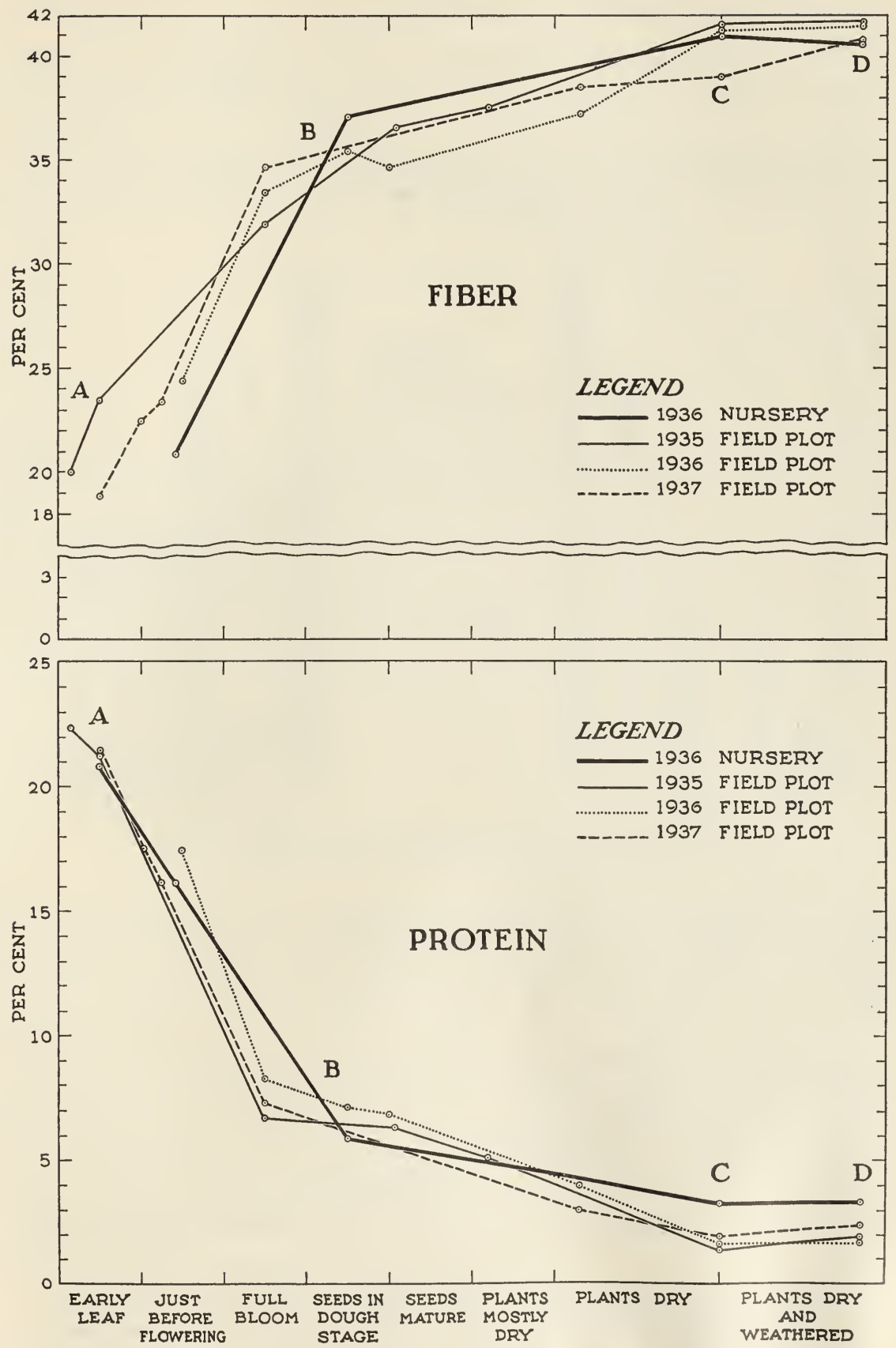

Fig. 8.-March of crude protein and crude fiber in Avena barbata, an annual grass, for 1935, 1936, and 1937. 

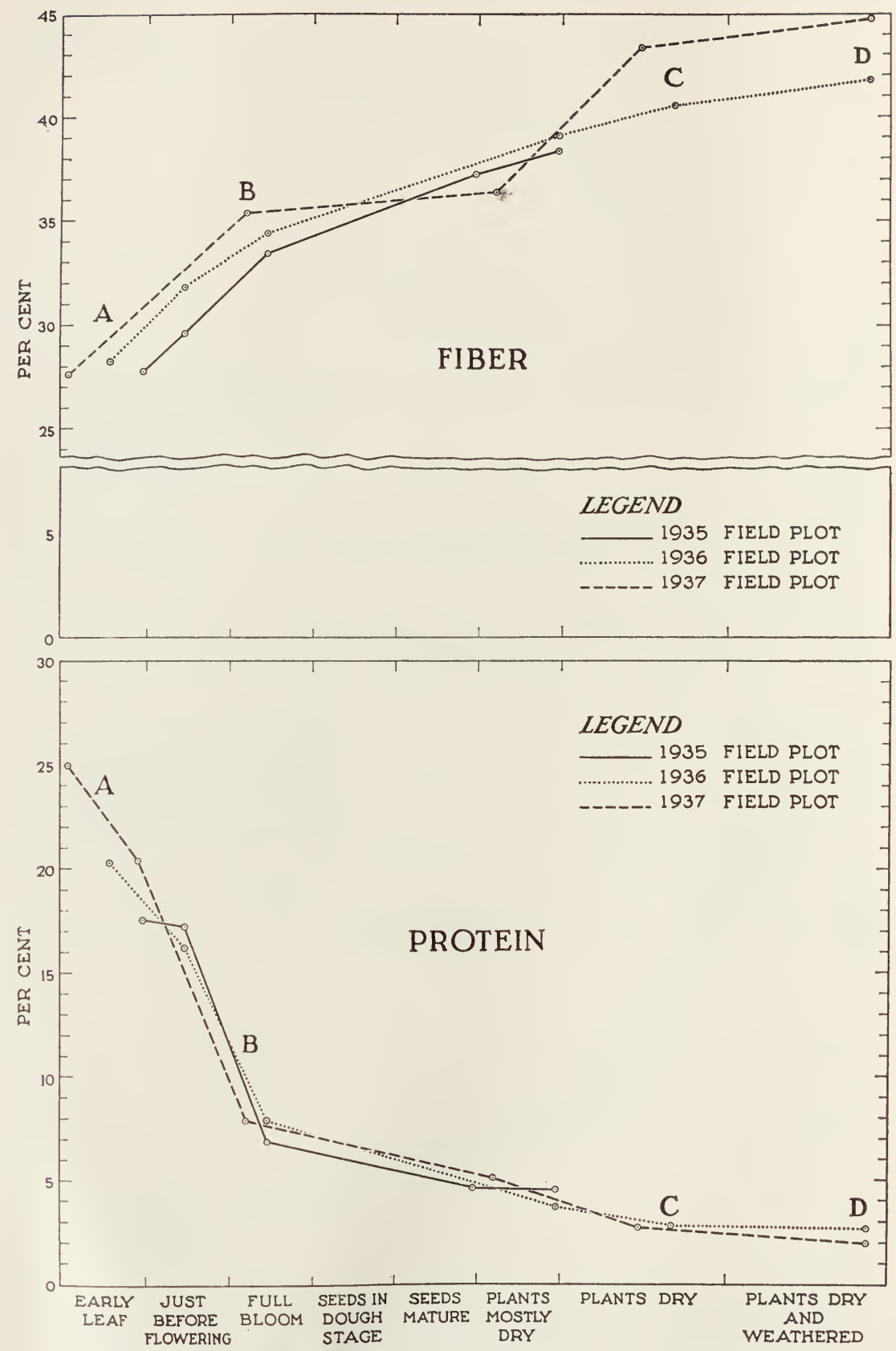

Fig. 9.-March of crude protein and crude fiber in Poa scabrella, a perennial grass, for 1935, 1936, and 1937. 
September-the levels of ash and potassium, as shown in segment $C D$, also remain practically constant. The greater smoothness of the curves representing the nursery samples is accounted for by the even age of the plants.

It is seen from table 1 that the highest silica-free ash content recorded for any grass species is 12.92 per cent, and the lowest is 1.61 per cent. In

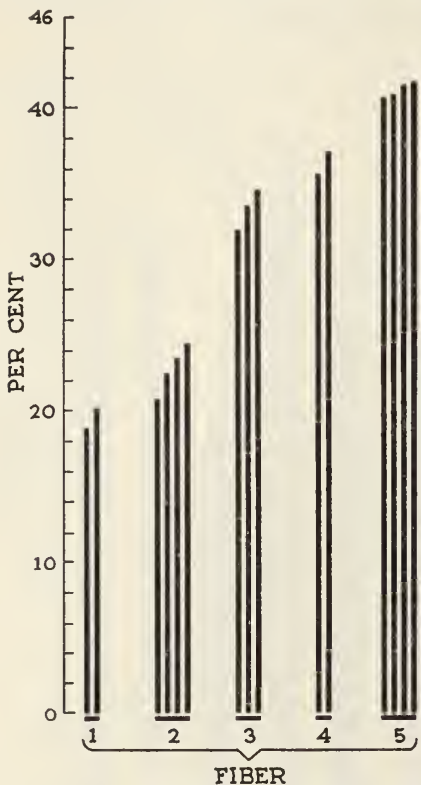

\section{Avena barbata}

1. Early leaf stage

2. Just before flowering

3. Full bloom

4. Seeds in dough stage

5. Plants mature, seeds cast

Fig. 10.-Crude protein and erude fiber in Avena barbata for five growth stages for 1935, 1936, and 1937.

the field plot of Bromus mollis, in 1936, the decline in ash content from the early leaf stage to maturity is 75.4 per cent; in Festuca megalura it is 74.7 per cent. The seasonal differences shown are representative of the grasses studied.

When the same growth stage of the various species is compared, the difference in the amount of ash is not conspicuous. When, for example, the highest and the lowest silica-free ash contents of all the grass species are compared for a given growth stage, the percentage differences are: in the early leaf stage, 60.9 per cent; at time of blossoming, 57.9 per cent; and at maturity, 70.0 per cent. The seeds of the grasses are very low in silica-free ash, ranging from 2 to 3 per cent.

The potassium content shows a general downward trend throughout the growing period, most of the species reaching the lowest values at full maturity. In Avena barbata (fig. 12) the potassium content increases slightly from the time the seeds are in the dough stage to maturity. This 
behavior is probably accounted for by the fact that a portion of the first spring leafage matures early and is lost under field conditions, and is, therefore, not available for inclusion in the sample. Calculations made from table 1 give a maximum difference between the highest and lowest content of potassium in $A$. barbata for the three years reported of 66.3 per cent, and in Bromus mollis of 80.1 per cent. In the other species studied similar variations in potassium content are found.

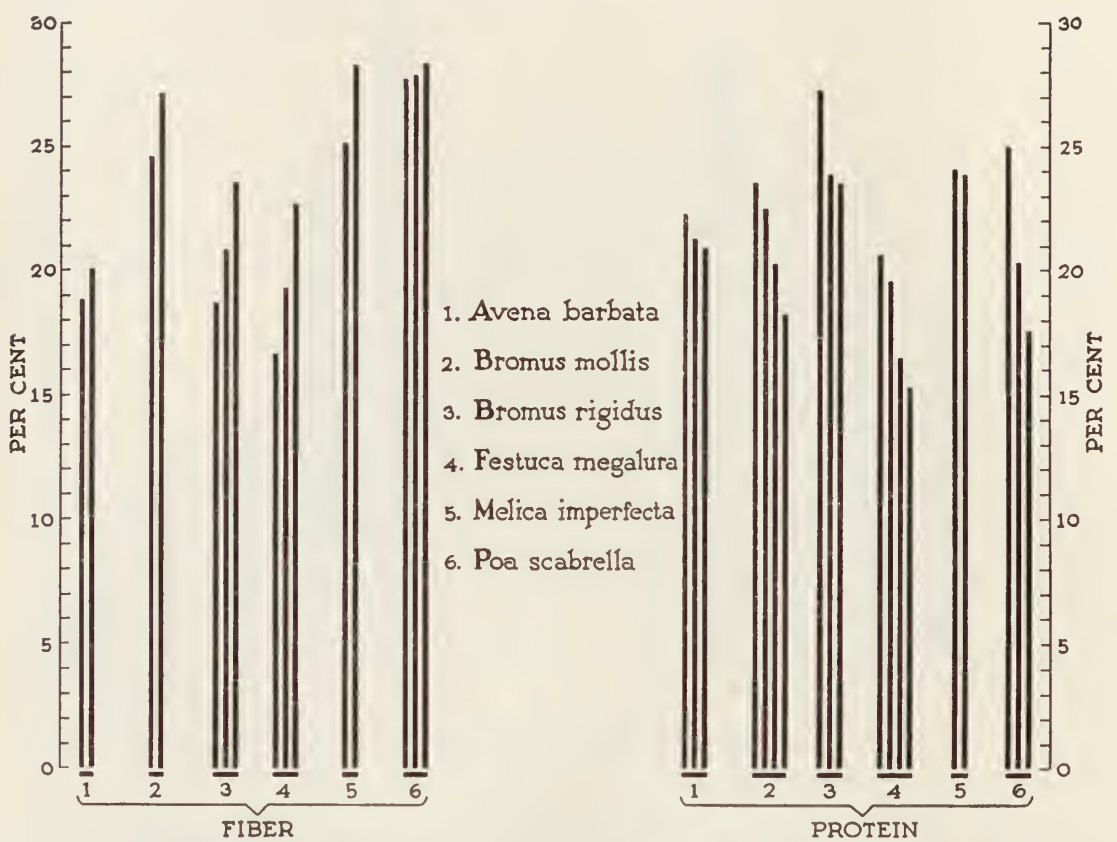

Fig. 11.-Crude protein and crude fiber in the early leaf stage of some of the grass species studied.

The potassium levels for a given growth stage show little difference in any of the species for the three years of study. Also, the levels of this constituent are seen to differ less in any specific growth stage for all the grass species investigated than for a given species for the entire growing season. In the early leaf stage of Avena barbata in 1935, 1936, and in 1937, there is a variation in the potassium content of only 34.9 per cent, and in Bromus mollis for 1936 and 1937 of 14.5 per cent. A similar relation holds for the other species studied.

The preceding discussion, based as it is upon three successive years of study of eight dominant annual and perennial grass species, is convincing of the fact that analytical data of a species whose sample is not representative of a specific growth stage, has little or no bearing on the 

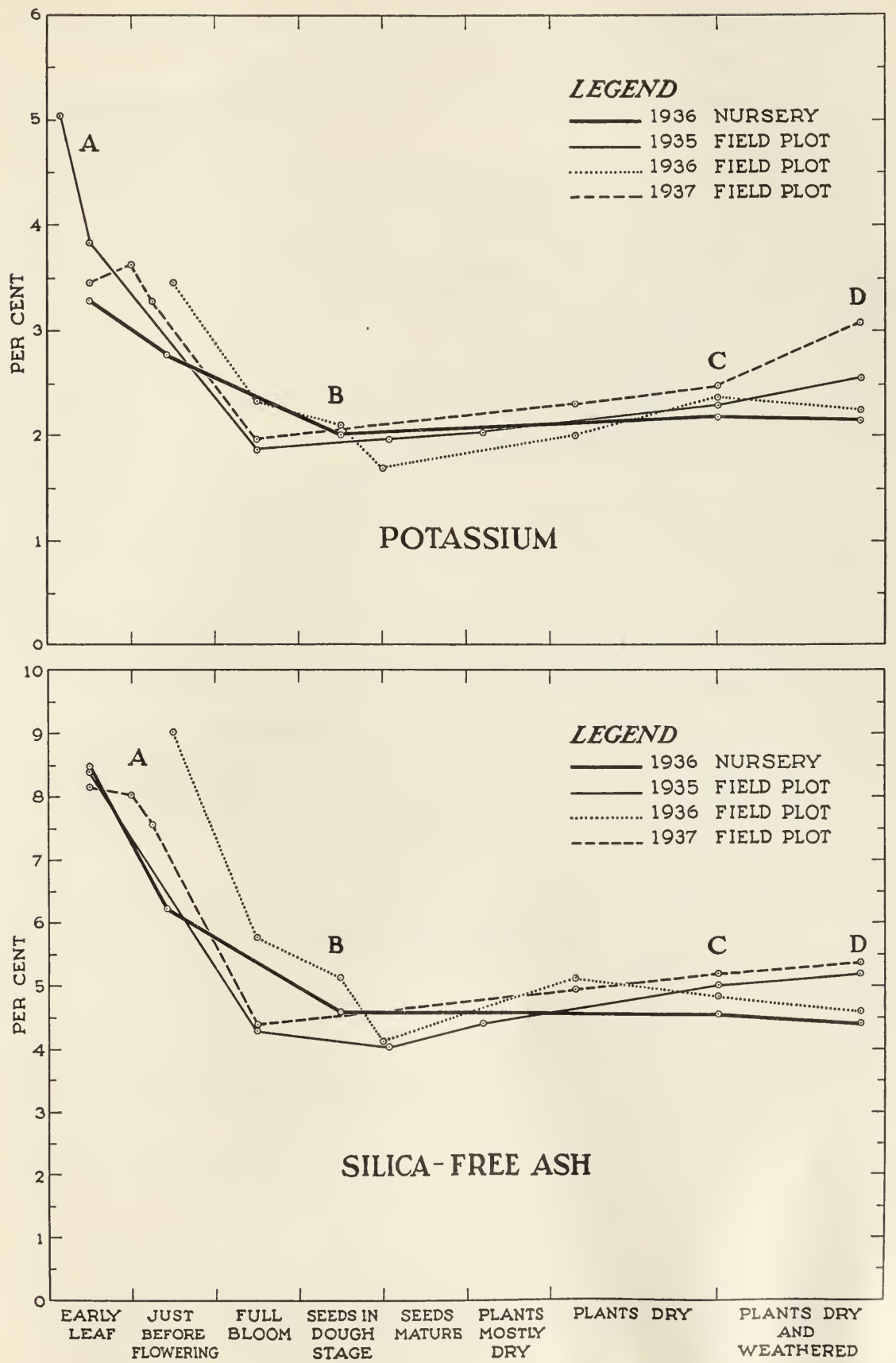

Fig. 12.-March of silica-free ash and potassium in Avena barbata for 1935,1936 , and 1937. 

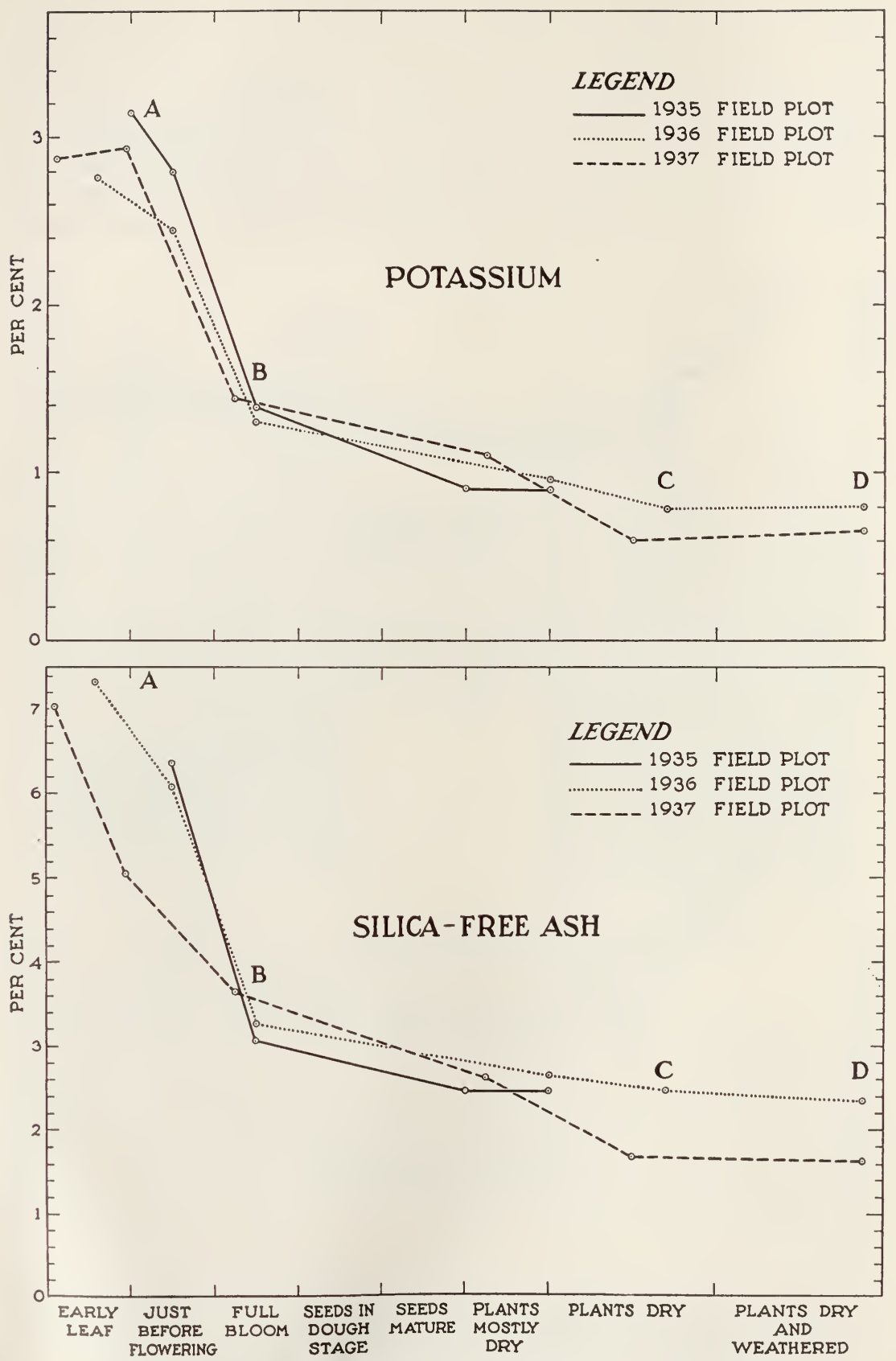

Fig. 13.-March of silica-free ash and potassium in Poa scabrella for 1935, 1936, and 1937. 
nutritional value of the plant. Moreover, the mere analysis of a species at a single growth stage affords little information as to the value of a species as a range plant, nor does it contribute to the problem of maintenance of the forage cover.

The potassium content in the seeds is low, being less than 1 per cent, and is even lower than in the mature, weathered plant.

In calcium and phosphorus the rate of the seasonal decline for Avena barbata and Poa scabrella is shown in figures 14 and 15. In calcium, the rapid decline is from the early leaf stage to late bloom, designated as $A B$ in the figures, whereas in phosphorus there is a somewhat more gradual and continuous decline from the time of early growth to maturity, designated as $A C$. In each of these constituents there is no appreciable change in the levels from the time that the herbage dries to the end of the dry, hot summer, designated as $C D$.

Shortening of the growing season of the grasses, since it affords only a short period for absorption, evidently results in a lower level of those constituents which occur limitedly in the soil solution, or those which are absorbed slowly. The samples collected in the nursery represent plants of a growing season shorter by more than 8 weeks than that of those collected in the field plots, the seeding in the nursery having been done long after growth had started on the range generally. At all points throughout the growth cycle the percentages of calcium and phosphorus are much lower than in the field samples, as typified in Avena barbata in figure 14. In contrast to these lower levels, the length of the growing season has no effect on the percentage of silica-free ash, potassium, protein, and the other constituents studied, as seen in figures 8 and 12. The difference in concentration and in the rate of supply of these three elements in the soil solution may account for the difference in accumulation of these constituents in the grasses studied. In a nearly neutral soil, such as that here concerned, the phosphorus content is less than three parts per million. In a short growing season the potassium content, being more abundant in the soil solution than is phosphorus, for example, appears to be absorbed in much larger relative amounts. This finding may have an important bearing on the phosphorus content of grasses grown at high elevations, or when limited precipitation curtails the length of the period of growth. In January, 1937, on the range studied, when the temperatures dropped so low as to freeze the tip of the young leafage, there was a lowering of the phosphorus content in the early growth stage. This low level was followed by rapid increase in phosphorus, as shown in segment $A B$ of figure 14, after which the values of this constituent assumed the usual trend. 

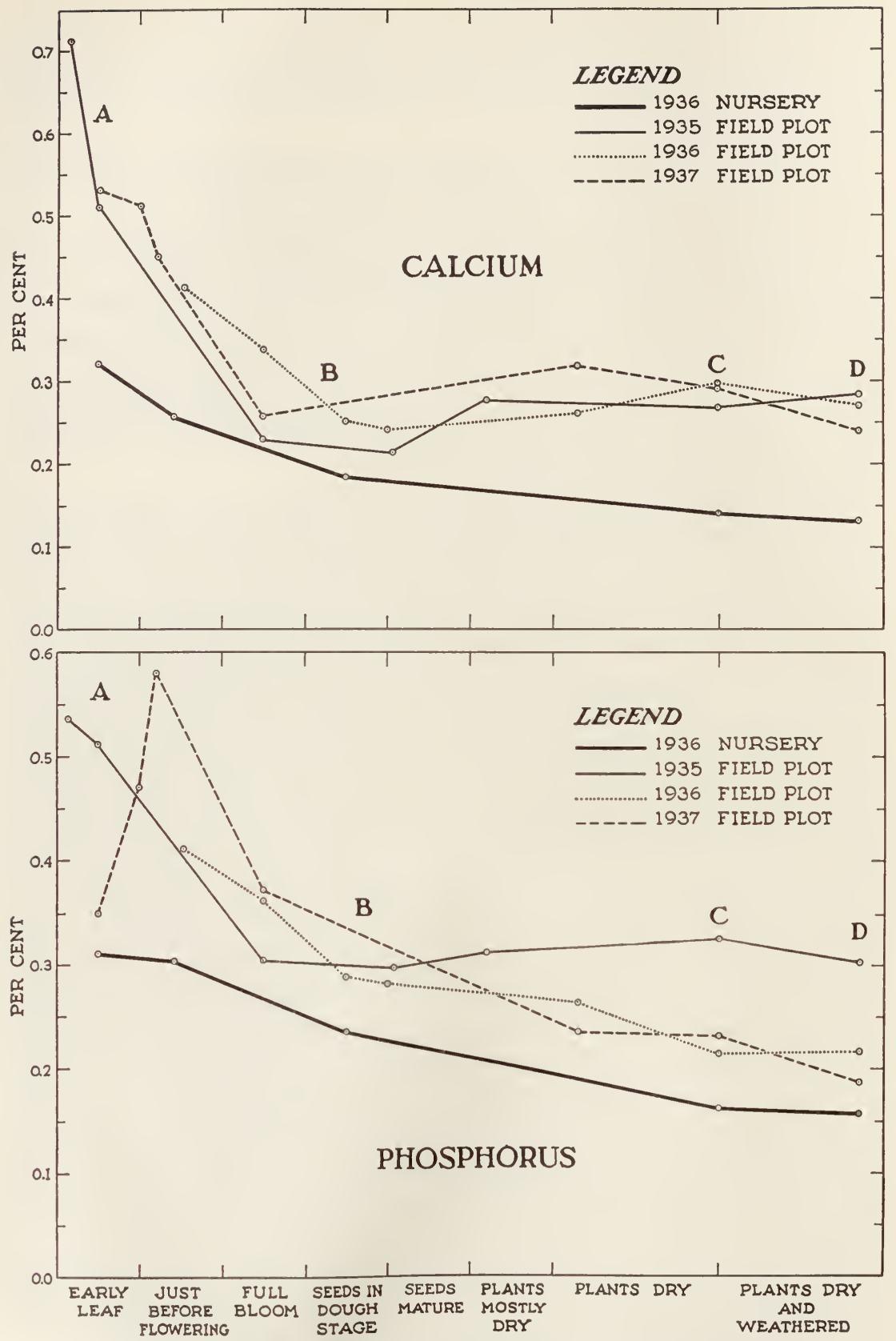

Fig. 14.-March of calcium and phosphorus in Avena barbata for 1935, 1936, and 1937. 

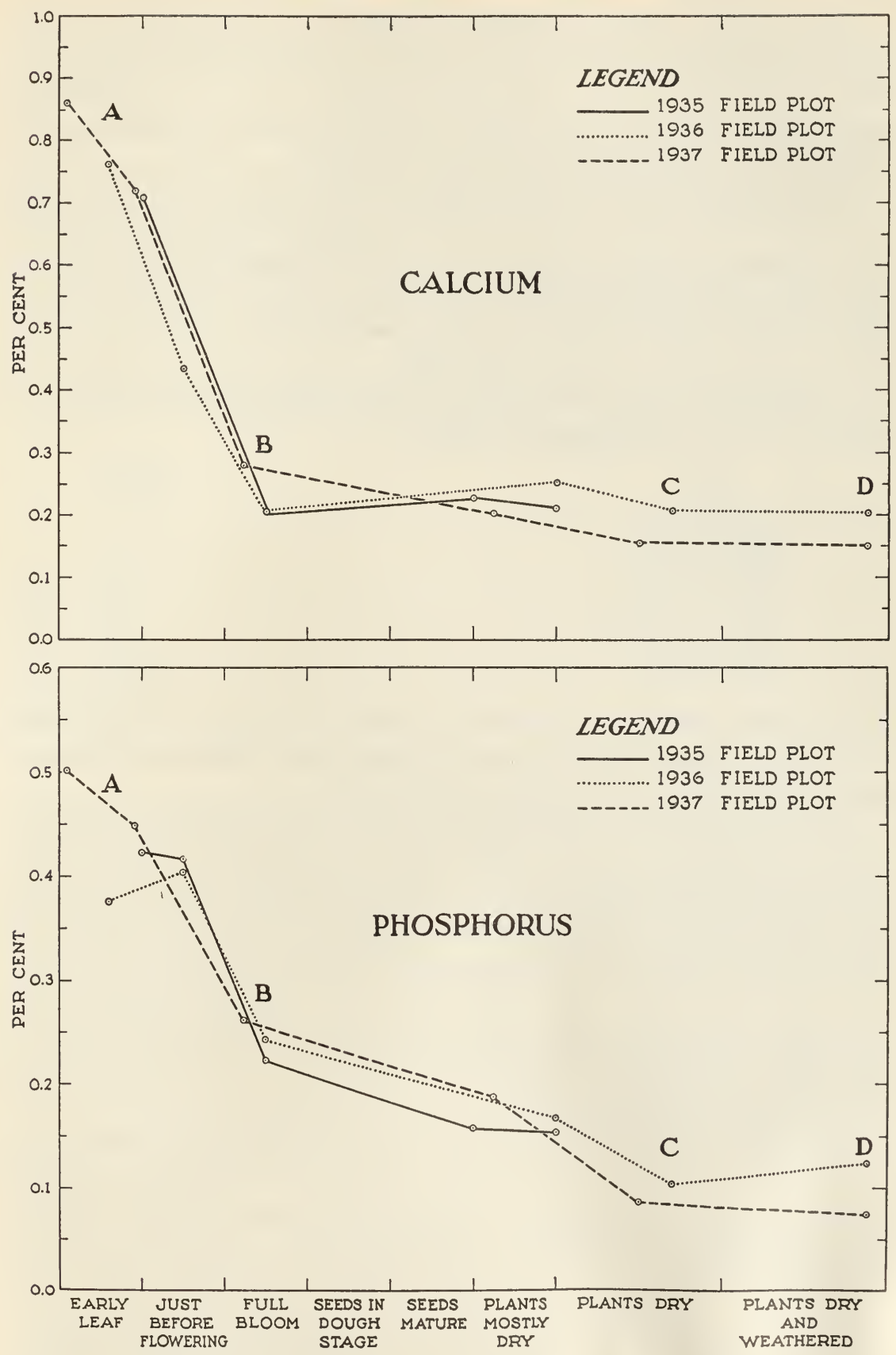

Fig. 15.-March of calcium and phosphorus in Poa scabrella for 1935,1936 , and 1937. 
The tendency for the mineral constituents to change little in their values after the blossoming period, as shown in segments $C D$ of figure 14 , may be accounted for by decreased absorption due to curtailment of physiological activities, associated, as this function is, with decreased production of root hairs as the season advances.

The calcium content in Avena barbata, collected on the regular field plot (table 1) shows a decline of 60.0 per cent in 1935 and 54.4 per cent in 1937, from the first to the last collection. Such seasonal decline in calcium holds proportionally for all the other species investigated. In the same growth stage the various grasses studied show a variation in calcium of approximately the same values as that for the entire growth cycle of a single species. The following data illustrate this point for the grasses in the early leaf stage, in 1937 :

\begin{tabular}{|c|c|}
\hline Species & $\begin{array}{l}\text { Calcium, } \\
\text { per cent }\end{array}$ \\
\hline Avena barbata.. & 0.533 \\
\hline Bromus mollis & .672 \\
\hline Bromus rigidus... & .922 \\
\hline Festuca megalura & 462 \\
\hline Melica imperfecta & .947 \\
\hline Poa scabrella . & 0.865 \\
\hline
\end{tabular}

It is seen that a difference between the highest and lowest calcium content of the six species is 51.2 per cent, compared with a difference of 54.4 per cent in $A$. barbata for the entire growth period.

In phosphorus content the same general tendency holds as for calcium, with the exception that the decline after the blooming period is more pronounced. From table 1 it may be calculated that the variation between the highest and the lowest phosphorus content in Avena barbata for the three years of study is 73.0 per cent, and in Bromus mollis it is 87.9 per cent. ${ }^{10}$ This declining trend with advancement towards maturity holds for all the other grass species. When, however, the same growth stage of the rarious grass species is compared, the difference between them in this constituent is relatively slight.

It is well known that the nutrients in the soil affect the composition of vegetation. Table 1 contains data on forage produced on a heavily manured plot located near the Station headquarters where the " $\Lambda$ " horizon is especially well developed. In Bromus rigidus, collected on this plot in 1937, the phosphorus and protein contents are higher, whereas the

${ }^{10}$ The figure for Avena barbata for 1937 is rather low for the growth stage concerned, and is accounted for by the fact that the sample was collected from regeneration growth following a heavy freeze of the earlier leafage. It will be noted from table 1 that in later collections in 1937 the phosphorus content increases to average amounts, and declines subsequently. 
calcium and fiber contents are lower than those in the samples taken on the regular field plot. The potassium content, on the other hand, is little affected.

From these data, and unreported work of the authors, it would appear that the soil solution and length of growing season modify the characteristic levels of the constituents studied, except in the case of potassium which is but slightly influenced.

The calcium content in the seeds is generally lower than that of the mature herbage. The phosphorus content in the seeds is relatively high,

TABLE 2

Calcium-Phosphorus Ratio of the Grasses for Alu Growth Stages For EACH OF THREE SUCCEssive YEARS

\begin{tabular}{|c|c|c|c|c|}
\hline \multirow{2}{*}{ Species } & \multirow{2}{*}{$\begin{array}{c}1935 \\
\text { Field plot }\end{array}$} & \multicolumn{2}{|c|}{1936} & \multirow{2}{*}{$\begin{array}{l}1937 \\
\text { Field plot }\end{array}$} \\
\hline & & Field plot & $\begin{array}{c}\text { Nursery } \\
\text { plot }\end{array}$ & \\
\hline Avena barbata........... & 1.0 & 1.0 & 0.9 & 1.0 \\
\hline Bromus mollis........... & 0.7 & 1.1 & 1.2 & 1.0 \\
\hline Bromus rigidus...... & 1.2 & 1.2 & .. & 1.6 \\
\hline Bromus rubens............... & 1.2 & 1.2 & 1.6 & 1.0 \\
\hline Festuca megalura............... & 1.0 & 1.0 & 1.6 & 1.1 \\
\hline Melica imperfecta............. & $\ldots$ & 1.3 & $\ldots$ & 1.8 \\
\hline Poa scabrella.................. & 1.2 & 1.5 & $\ldots$ & 1.5 \\
\hline
\end{tabular}

and approximates the level found in the aerial growth up to the time that the seeds begin to form.

The Calcium-Phosphorus Ratio.-The calcium-phosphorus ratio in herbage is an important factor for foraging animals. To what extent this ratio varies in the different groups of related plants is of scientific interest and of economic importance. The ratios, for the grass species studied, are presented in table 2.

Table 2 brings out the fact that in the grass species the averaged calcium-phosphorus ratio for all growth stages is not far from 1. Although the environmental factors may influence the percentages of calcium and phosphorus, the data show that the effect is not such as to change the ratio perceptibly.

Table 3 reports the calculated calcium-phosphorus ratio of Avena barbata in seven growth stages. The data show that the calcium-phosphorus ratio in $A$. barbata holds near to 1 for all the growth stages. This ratio is characteristic of the other grass species studied.

Evaluation of the Species as Forage.-From the preceding discussion it is evident that all the grass species here investigated are high in caloric values, and in minerals, from the early leaf stage until they have come 
into full bloom. Accordingly, the forage value of an annual range grass is greatest during the interval of time between the earliest appearance of the leaf blades and the date when the seeds begin to form, a period when all essential constituents are maintained at a relatively high level.

Festuca megalura has a short growth period; its value as range forage is virtually over when the plant is in full bloom. From table 1 it is seen that the late flowering period is reached in approximately 2 months after

TABLE 3

Calcium-Phosphorus Ratio of Avena Barbata at Various Growth Stages FOR THREe SUCCESSIVE YeARS

\begin{tabular}{|c|c|c|c|c|}
\hline \multirow{2}{*}{ Growth stage } & \multirow{2}{*}{$\begin{array}{c}1935 \\
\text { Field plot }\end{array}$} & \multicolumn{2}{|c|}{1936} & \multirow{2}{*}{$\begin{array}{l}1937 \\
\text { Field plot }\end{array}$} \\
\hline & & Field plot & $\begin{array}{l}\text { Nursery } \\
\text { plot }\end{array}$ & \\
\hline Early leaf stage........ & $1.2^{*}$ & $\ldots$ & 1.0 & 1.5 \\
\hline Just before flowering.............. & $\ldots$ & 1.0 & 0.8 & $0.9^{*}$ \\
\hline Plants in full bloom............... & 0.8 & 0.9 & $\ldots$ & 0.7 \\
\hline Seeds in dough stage.............. & $\cdots$ & 0.9 & 0.8 & $\ldots$ \\
\hline Leaves mostly dry, some seeds cast.. & 0.9 & 1.0 & $\ldots$ & 1.4 \\
\hline Aerial growth dry, seeds cast......... & 0.8 & 1.4 & 0.9 & 1.3 \\
\hline Plants dry and weathered, seeds cast & 0.9 & 1.3 & 0.8 & 1.0 \\
\hline Average. . & 0.9 & 1.1 & 0.9 & 1.1 \\
\hline
\end{tabular}

* Average of two samples at the same stage.

the earliest leafage appears. In Poa scabrella, although a perennial, the interval between the early leaf stage and flowering is also short, and the decline in protein and mineral constituents is rapid. Avena barbata only slightly outranks $F$. megalura and $P$. scabrella as a range plant, chemical characteristics alone considered. These three species are inferior as forage because of the unfavorable nutritional balance at the onset of blossoming. On the other hand, Bromus mollis, a species widely distributed and often abundant in the foothills of the state, contains a relatively high percentage of protein at the time of blossoming; and even at maturity this constituent is relatively high because of the retention of the seeds. The mature panicles, with the seeds intact, contain 12.53 per cent crude protein and only 17.23 per cent crude fiber. B. rubens, although mechanically objectionable as forage when the awns are developed, is nevertheless of about the same nutritional value as $B$. mollis. Melica imperfecta, a perennial which blossoms and matures late in the season, maintains a high nutritional level even after the seeds have reached the dough stage.

From the preceding discussion it becomes evident that the following three characteristics are among the important factors in the evaluation 
of range grasses from the standpoint of their composition: (1) the interval between the earliest appearance of leafage to full bloom must be long; (2) the crude protein content must remain at a relatively high level after the blossoming period, and well into the time that the seeds attain the dough stage; even after seed dissemination it is desirable that a portion of the basal leaves and stems remain succulent until late in the summer-a characteristic of many perennial grasses; (3) in the species whose herbage matures early, a large proportion of the seeds must be retained after the leaf blades have become dry.

It is the opinion of the writers that the mineral constituents should not in general be regarded as the deciding factor in the evaluation of the range grasses studied. Indeed, the relatively few forage species which contain unusually large quantities of sodium chloride, silica, and selenium, are undesirable primarily because of the toxicity of the mineral content. Ingle (26) and others have reported that forage plants containing as little as 0.05 per cent phosphorus are deficient for domestic livestock; and Hall and Russell (20) concluded that 0.25 per cent phosphorus is characteristic of superior forage.

All grass species here reported, and particularly those which retain their seeds long after maturity of the herbage, are generally adequate in calcium and phosphorus, provided these elements are fully utilized by foraging animals. That components other than the percentage of the mineral matter may determine the range value of a species (provided it is palatable) is well illustrated in Avena barbata, which, although of very low protein content when the seeds are cast, contains more silicafree ash than any other grass species here investigated. Table 1 shows that only in three instances, all of which occurred at full maturity in the grass species studied, does the phosphorus decline to, or approach, the deficiency level of 0.05 per cent. It is significant that these deficiencies occurred in the grass samples collected in the Station nursery, where the growing season was much shorter than on the regular field plot.

\section{COMPOSITION OF GRASSLIKE SPECIES}

Three grasslike species were included in the study, namely, Juncus bufonius, J. oxymeris, and Eleocharis palustris. These species compose much of the cover in the meadowlike swales of the San Joaquin Experimental Range, and the latter two species furnish palatable forage in the summer and early autumn after most of the true grass cover has become dry (fig. 1). This meadow type is generally under water for several weeks during the period of heavy precipitation. Soon after the water recedes, the stand forms nearly a complete ground cover, the herbage of which 


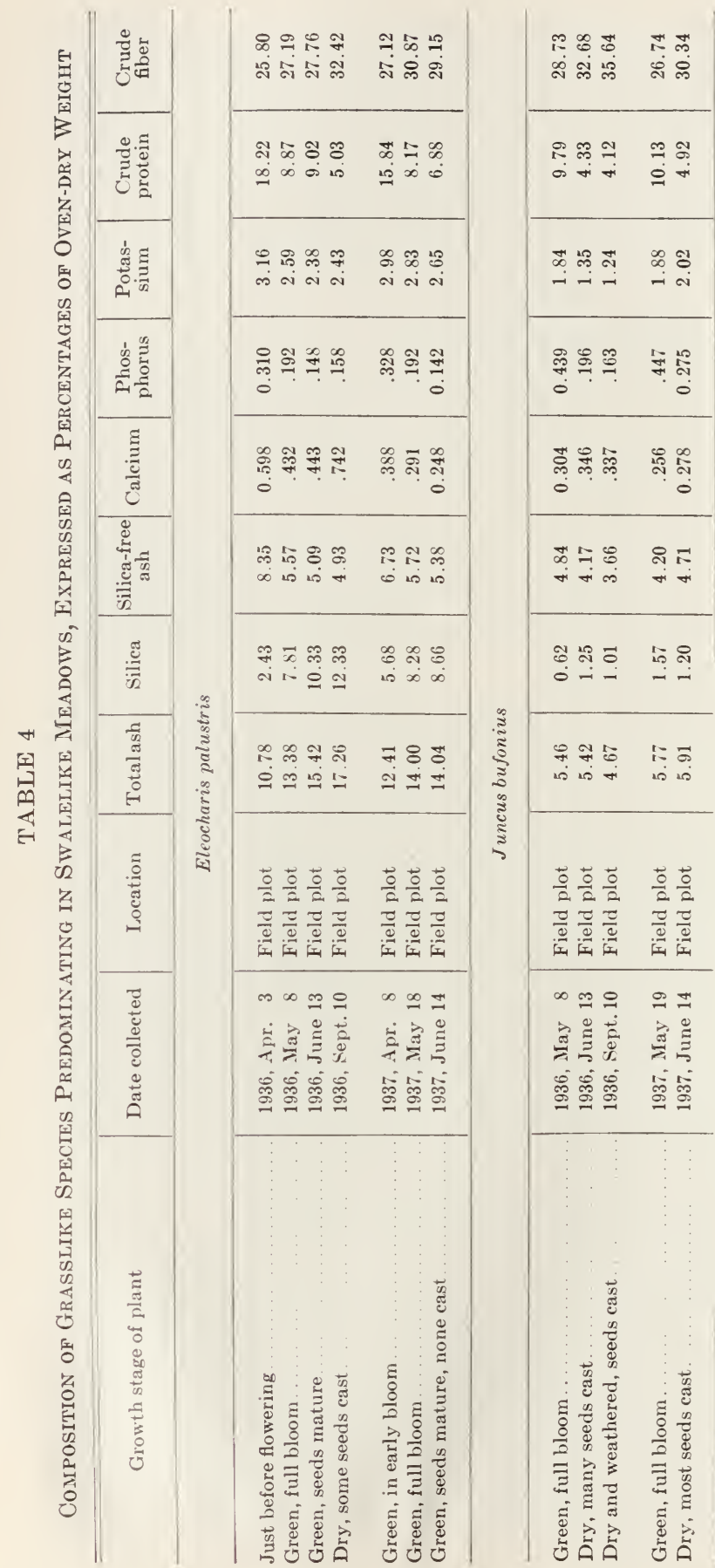

ஐ ஜ

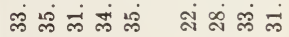

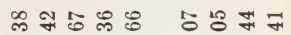

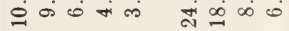

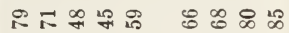

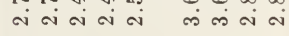

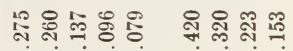
$\circ$ o

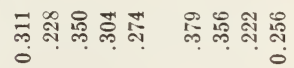

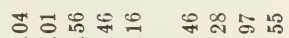
0 in an a 0 is

Fี - - i

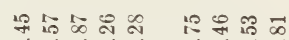

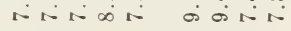

늠

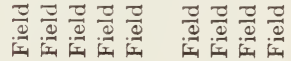

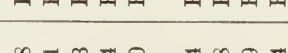
$\infty=\cong \Xi \quad+\infty \stackrel{\square}{\square}$

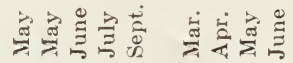

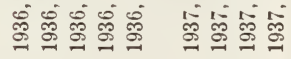

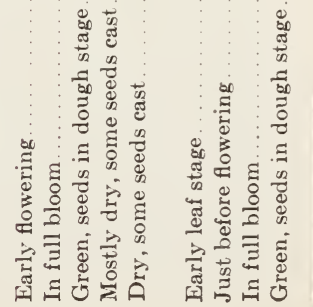


remains more or less succulent until late in August, and often into September.

The constituents of these grasslike species exhibit trends similar to those of the corresponding components in the grasses. There is an orderly trend in the same direction in the organic and inorganic constituents from the early leaf stage to maturity. The change in composition is rapid from the time of the earliest appearance of leafage to the flowering stage. From then on the changes are slight, if they occur at all.

Organic Constituents.-Table 4 shows that there is little difference in the crude protein content in the three grasslike species here reported, when the same growth stages are compared. When the entire growth cycle of the species is considered, however, there is a decline in the protein content from the early leaf stage until the herbage is dry.

The crude fiber content in the three species studied shows the same general behavior, being lowest in the early growth stage and highest at maturity. After the flowering period is reached there is little increase in fiber." In Juncus oxymeris, for example, the fiber content is 50.1 per cent higher in the flowering stage than in the early leaf stage and changes but little to full maturity-leaf stage-these comparisons being made from 1936 and 1937 data. The data show that the difference in the percentage of protein and of fiber for a single growth stage of this plant group is less than that for any one of these species for the entire period of growth.

Inorganic Constituents.-Table 4 shows that Eleocharis palustris is conspicuously high in silica, containing, in fact, the highest percentage of this constituent of any species investigated, reaching 12.33 per cent at maturity. ${ }^{12}$

The silica-free ash in the grasslike species is highest in the early leaf stage. After reaching the bloom stage there is little change in this constituent. The levels of ash of the species of this group are similar at specific growth stages.

In calcium content these species lack consistency in trend from the early leaf stage to the flowering period. From the latter period on to maturity, however, there is little fluctuation. In phosphorus content, on the other hand, there is a gradual decrease from the early leaf develop-

11 The slight irregularities in the trend of the fiber representing the various growth stages is presumably accounted for by the fact that the samples, though pure as to species, were necessarily obtained from the average growth of a dense stand, rather than from selected individual specimens.

12 The high silica content at all growth stages of this species is significant in view of the fact that the samples immediately after collection were washed in several changes of water; but it is possible that the surficial soil silica was not entirely removed from the floral parts. 
ment to maturity, reaching the lowest point when the leafage has dried. In potassium content little change takes place through the life cycle, being only slightly higher in the early leaf period. Juncus bufonius is the lowest in potassium and silica-free ash of the three species.

Evaluation of the Species as Frorage.-In these species the calciumphosphorus ratio is approximately 1 in early stages of development, whereas at maturity it approaches 4 . As stated, the primary value of most of these species as range forage is that their succulence remains high when the herbage of most of the grasses and the broad-leaved species has dried. Although the protein values are relatively low, and the fiber content fairly high in midsummer, the levels of all the nutrients at that season are much higher than in the other herbaceous species. Eleocharis palustris, being very high in silica, appears to be of lesser value than the other two species. In silica-free ash and its constituents the grasslike species rank favorably with those of the grasses during the entire period of growth.

\section{COMPOSITION OF THE BROAD-LEAVED HERBS}

Twenty-five broad-leaved herbs were included in the study, these being representative of seven plant families. The list includes the most important forage species, and also some "range weeds," or plants of very low palatability for domestic foraging animals. The weed species studied are of interest because of their occasional conspicuous abundance in the plant community, and their presumed effect upon the soil and on plant succession.

Organic Constituents.-Figure 16 shows the trends of crude protein and crude fiber in Amsinckia Douglasiana - this species typifying fairly well the behavior of these constituents for the broad-leaved herbs. An impressive consistency exists in the levels of the protein and fiber contents in the same growth stage for the three successive years of study. The rate of change in protein and fiber is most rapid from the early leaf stage to the late blossom period, designated as $A B$ in figure 16 . From the latter period to maturity, indicated as $B C$, the change is less precipitous. The relative rate of change of these two growth stages holds for all but one group of species of the broad-leaved herbs studied. In the species of the legume family, as represented by Lupinus Benthami, the protein content invariably declines slowly and at nearly the same rate throughout the life cycle. It should be noted that the maximum and minimum protein and fiber levels, as recorded early in the season and at maturity, respectively, are of slightly higher values in the legumes than in the nonleguminous species. In the former species, the protein level 
remains relatively high throughout most of the growth period. It will be noted (table 5) that the characteristic protein values of the broadleaved species are little or not at all affected by slight variations in the length of the normal growth cycle. In the nursery, where the growing season was short, the percentage of protein for a given growth stage is of the same absolute value, and the rate of the seasonal decline, as shown by the shape of the curve (fig. 16), is identical with that of samples collected in the regular field plot.

Table 5, which gives the analytical data of this group, has similar arrangement to that of tables 1 and 4 ; but in this table the species are grouped consecutively according to family relationships. In stating the particular growth stage which the various samples represent, it should be recognized that not only is there variation in the growth stage of the individual plants which composed the sample, but also that parts of individual plants differed somewhat in the stage of development. Species of Erodium and Amsinckia are particularly difficult to sample for the reason that a single plant may simultaneously display a combination of buds, newly expanded flowers, and well-formed seeds. Although the various samples are composed predominantly of the growth stage designated, some material of a different stage of development may inadvertently have been included.

Table 5 shows that the protein content, although differing widely in amount in the various species, is highest in the early leaf stage and lowest at plant maturity. During the three years of investigation the range in crude protein for all species worked with, when in the early leaf stage, is from 16.07 per cent to 35.05 per cent, and at maturity, when the seeds have been cast, the range is from 12.36 per cent to 1.38 per cent. The variation within a species is fairly well typified in Silene gallica, in which there is a decline of 76.6 per cent during the growth cycle of 1936 . In contrast with this wide descending seasonal trend within a species the range in protein content in the early growth stage and at maturity is relatively slight. This point is shown in table 6 , compiled from table 5, which includes species belonging to different families.

The levels in protein content among the four species, in the early growth stage and at maturity ${ }^{13}$ respectively, are seen to vary but little. Moreover, the percentages of protein differ little from year to year in a given species. These species, however, show a characteristically wide variation in the protein levels at the flowering period, as seen when Lupinus Benthami and Hemizonia virgata are compared.

${ }^{13}$ The relatively high protein content reported for Lupinus Benthami is accounted for by the fact that portions of the pods retained their seeds at this sampling period. 


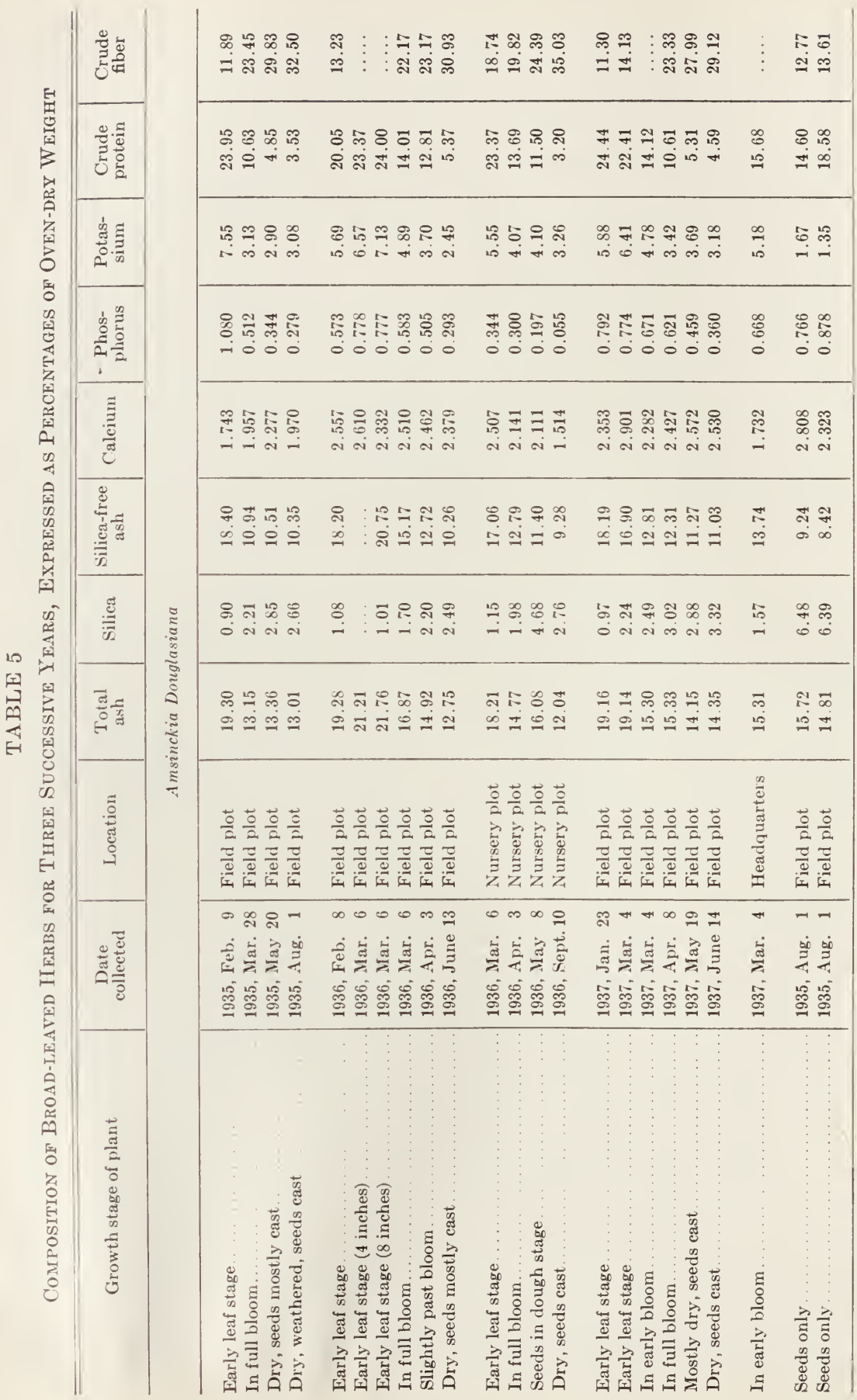




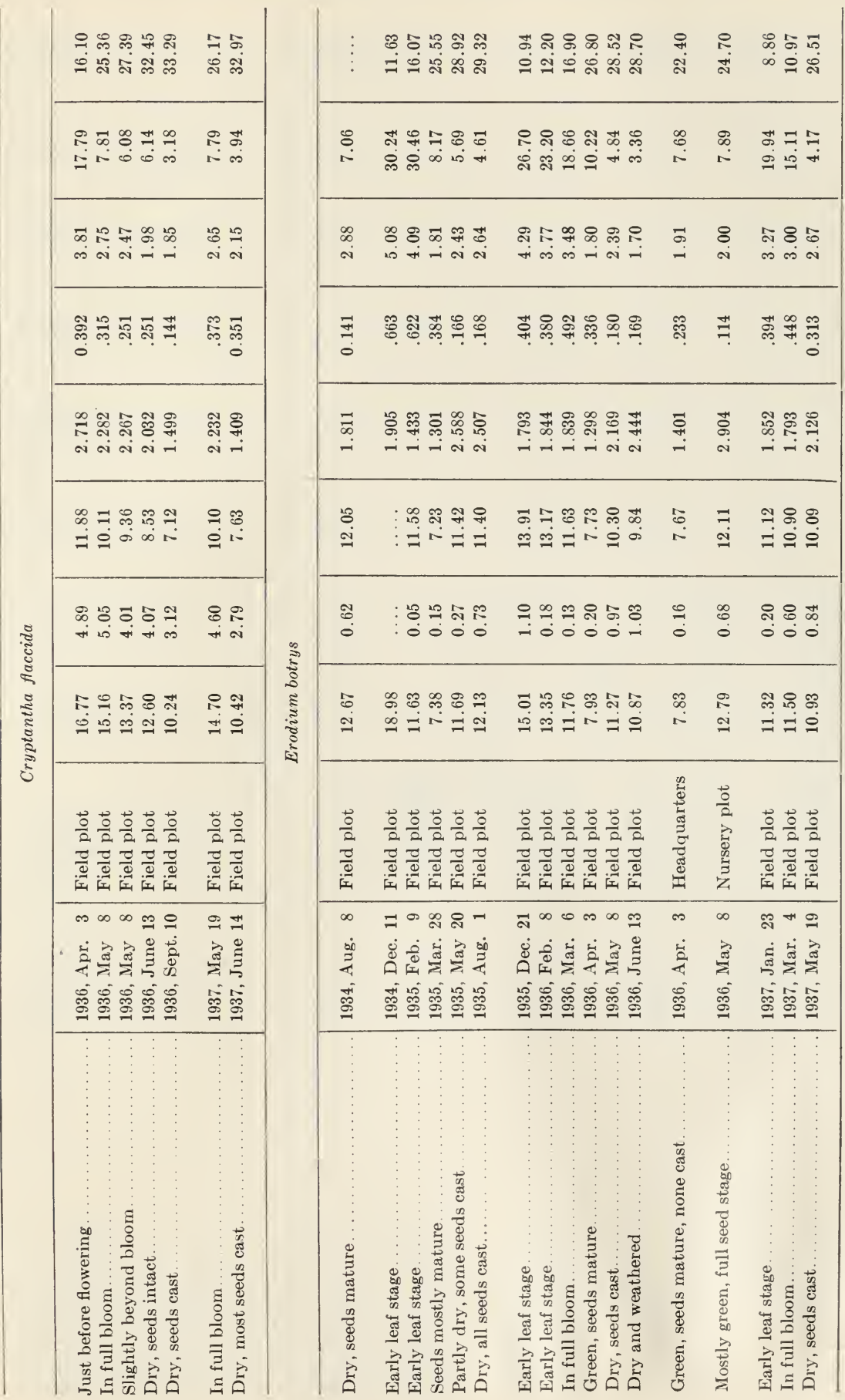




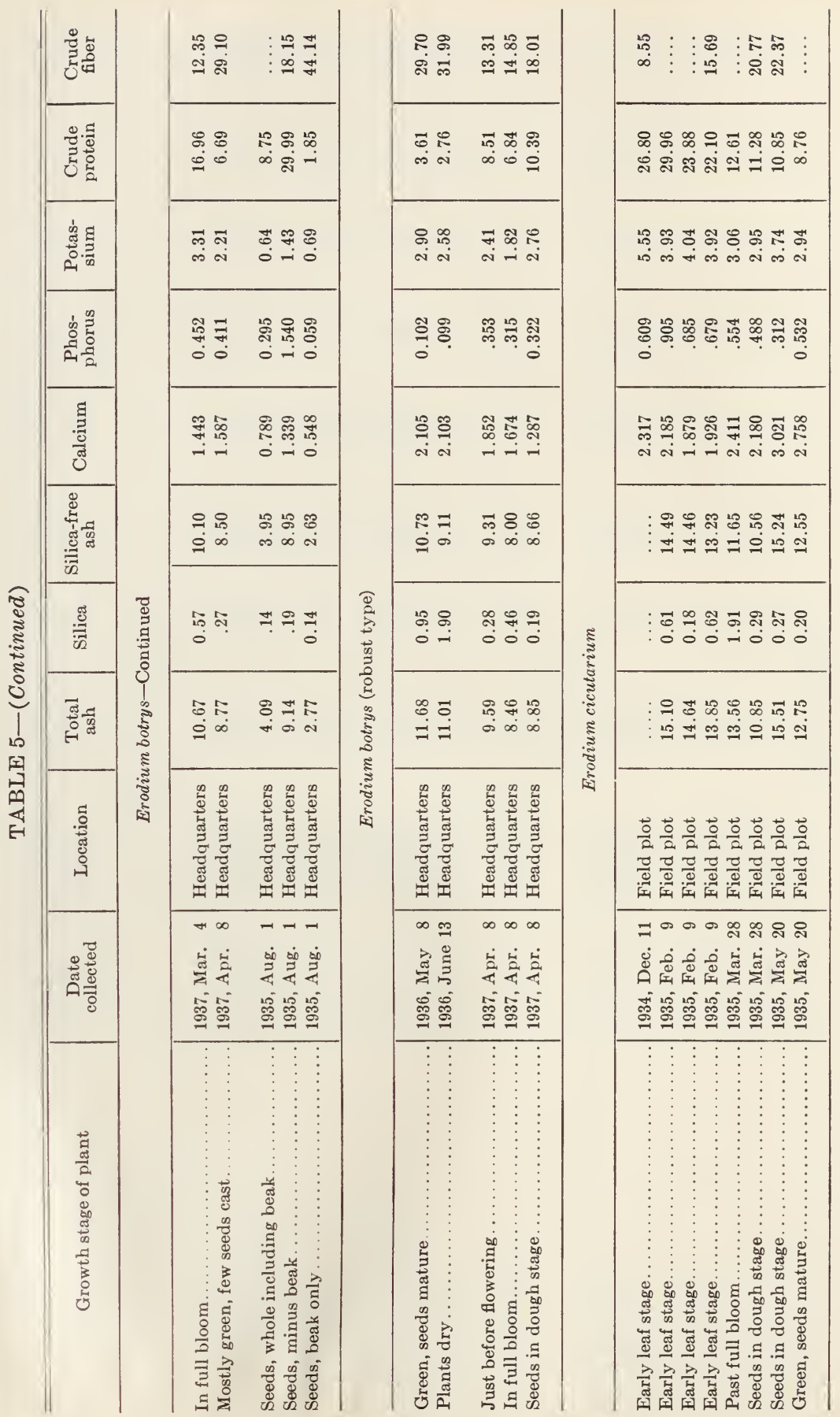




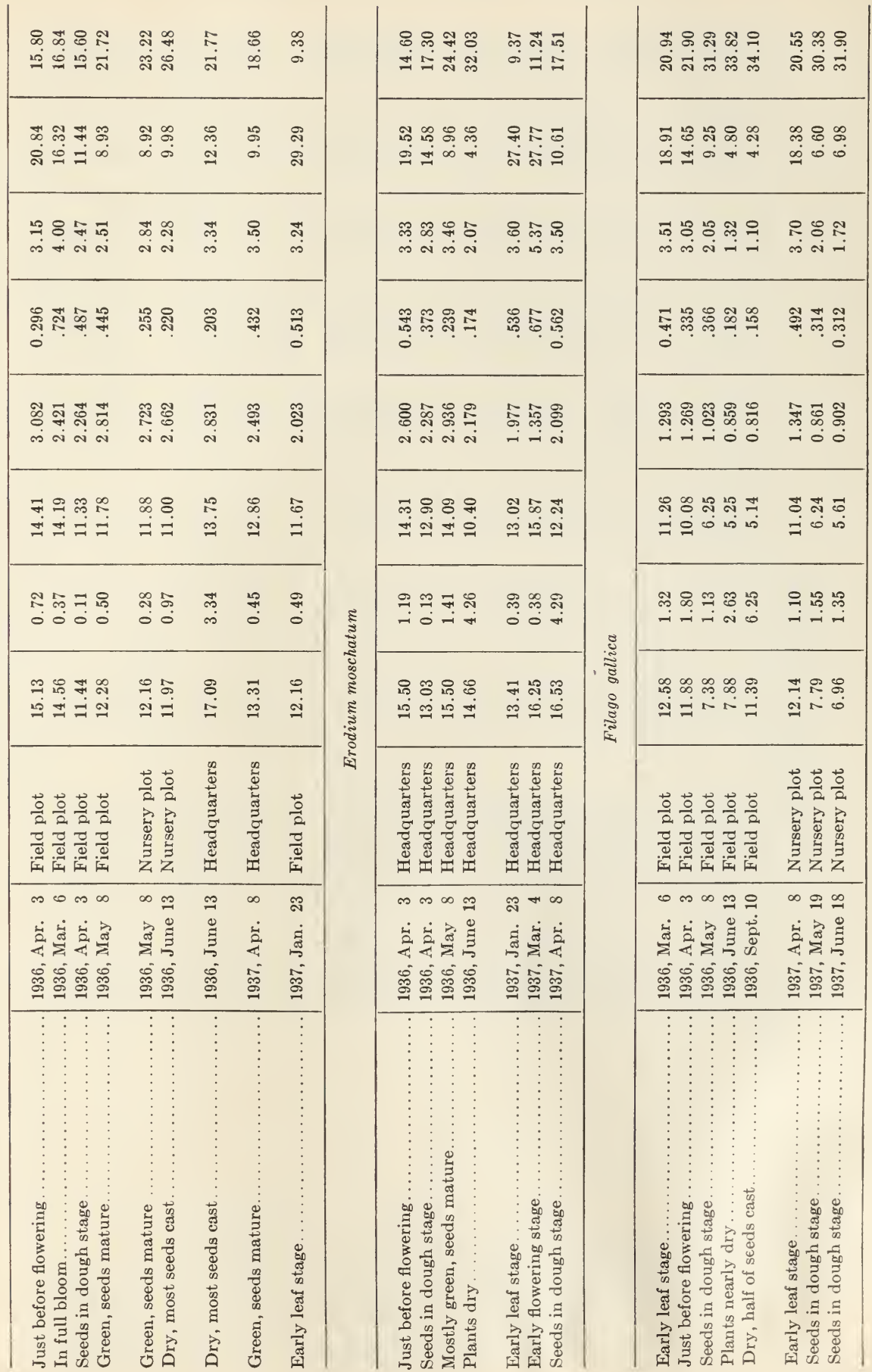




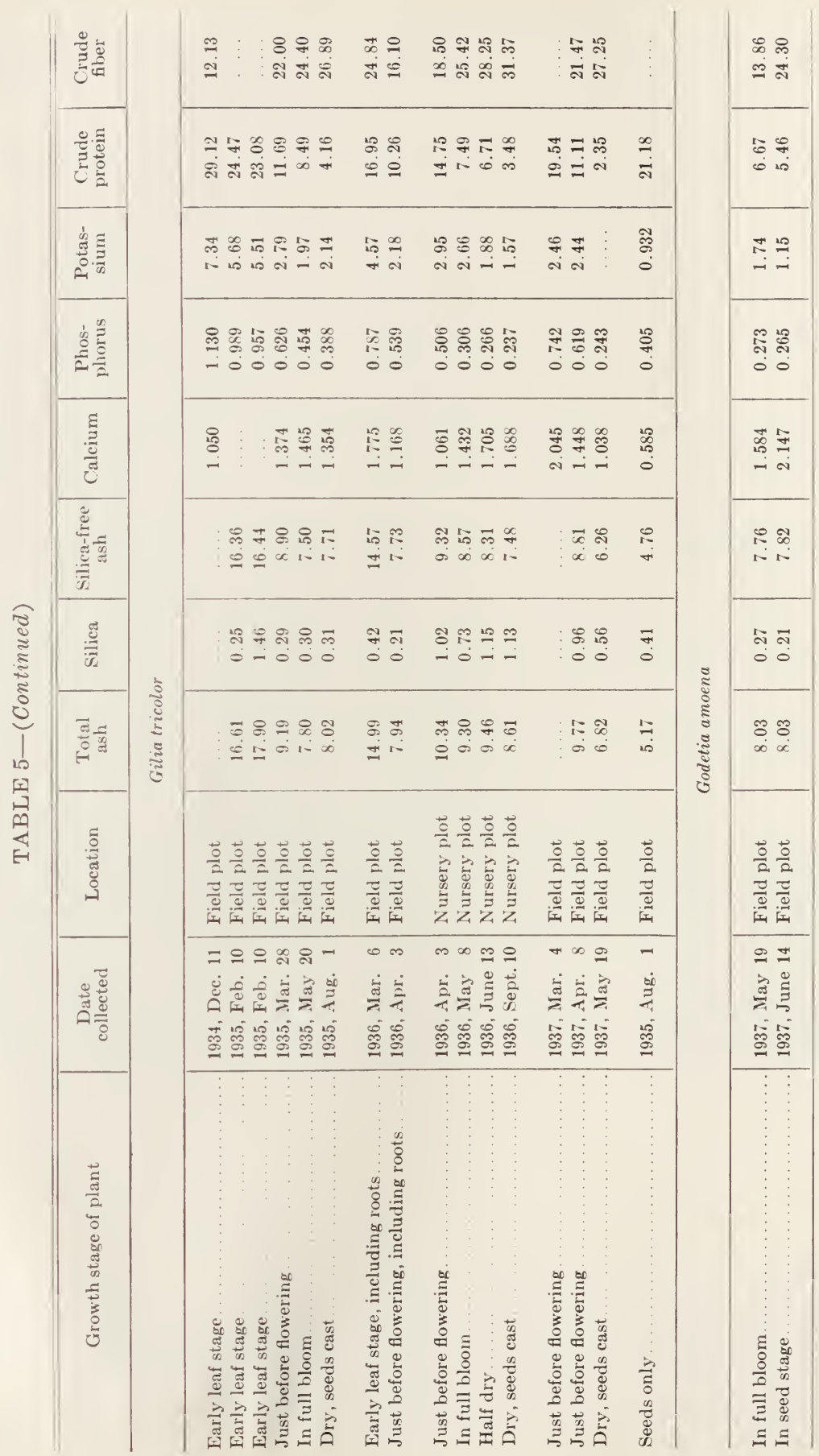




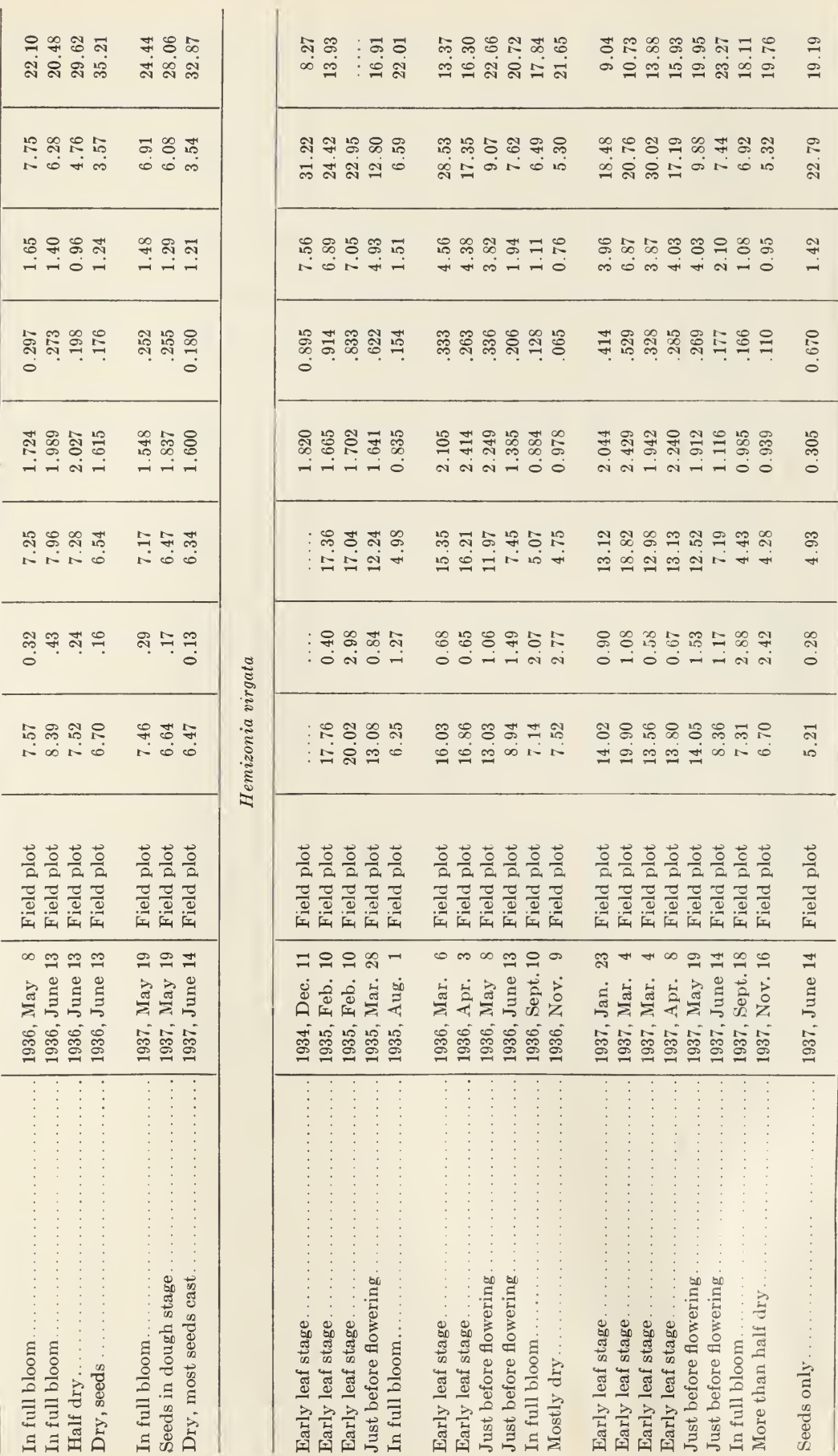




\begin{tabular}{|c|c|c|c|c|c|c|c|c|c|}
\hline 苟 & \multirow{11}{*}{ 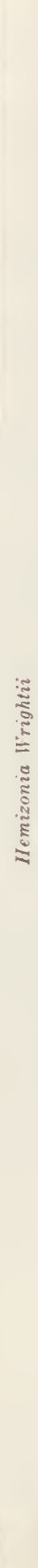 } & శ్లి & 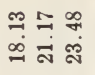 & \multirow{11}{*}{ 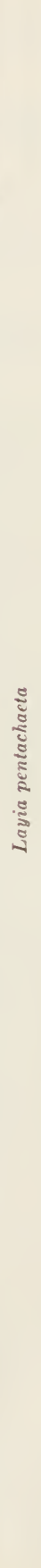 } & 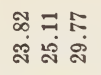 & 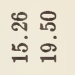 & 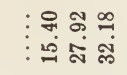 & 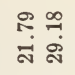 & 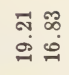 \\
\hline 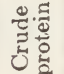 & & is & 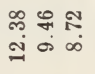 & & 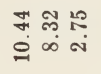 & 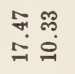 & 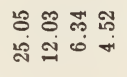 & 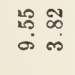 & 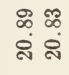 \\
\hline 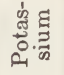 & & - & 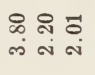 & & 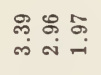 & 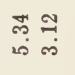 & 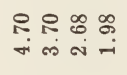 & 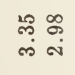 & $\stackrel{\mathscr{Z}}{\overparen{i}}$ \\
\hline 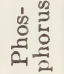 & & $\frac{\pi}{0}$ & 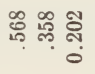 & & 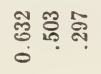 & 郘 & 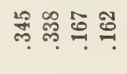 & 윰 & 象尊 \\
\hline 苞 & & ๕ั้ & 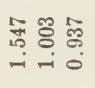 & & 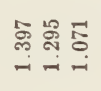 & 哭 & 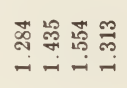 & స్ల్ల & 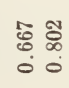 \\
\hline 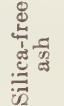 & & $\stackrel{\infty}{0}$ & 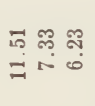 & & 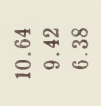 & $\begin{array}{l}\text { 웅 } \\
\text { 융 }\end{array}$ & $\begin{array}{l}=\pi 8 \\
=\infty i\end{array}$ & 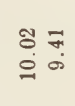 & $\begin{array}{lll}\infty & \infty \\
i \infty & -1 \\
i \infty & 0\end{array}$ \\
\hline 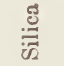 & & : & 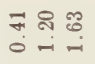 & & 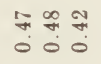 & 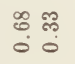 & 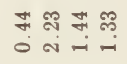 & : & 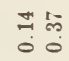 \\
\hline 푱 & & $\begin{array}{l}\text { \& } \\
6\end{array}$ & 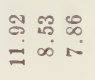 & & $\begin{array}{l}=80 \\
=00 \\
=00\end{array}$ & 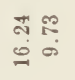 & 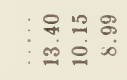 & $\begin{array}{l}5 \% \\
=0\end{array}$ & $\begin{array}{ll}0 & 10 \\
0 & 0 \\
0 & 0\end{array}$ \\
\hline ऽ̊ & & $\begin{array}{l}\frac{5}{2} \\
\frac{\bar{u}}{\mathrm{~d}}\end{array}$ & 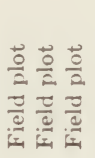 & & 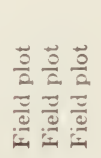 & 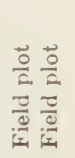 & 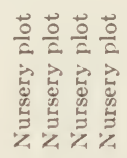 & 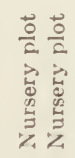 & 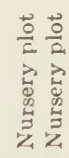 \\
\hline 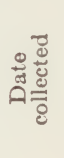 & & : & 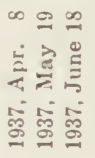 & & 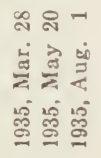 & 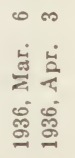 & 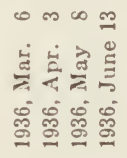 & 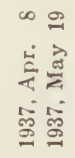 & 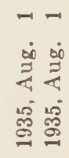 \\
\hline 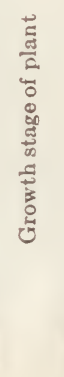 & & $\begin{array}{l}0 \\
0 \\
0 \\
0 \\
0 \\
0 \\
0 \\
0\end{array}$ & 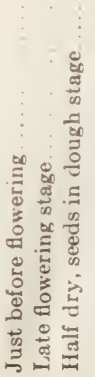 & & 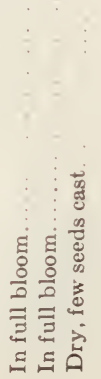 & 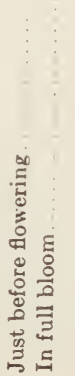 & 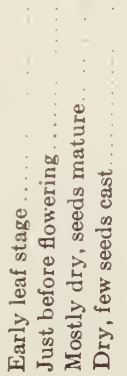 & 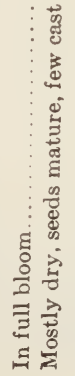 & 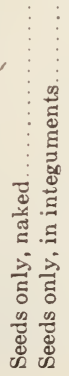 \\
\hline
\end{tabular}




\begin{tabular}{|c|c|c|c|c|c|c|c|c|c|}
\hline 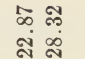 & 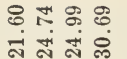 & \multirow{11}{*}{ 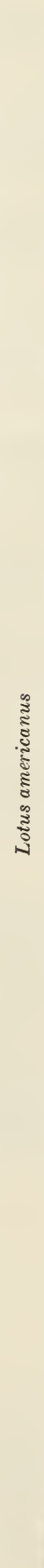 } & 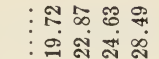 & $\underset{\mathscr{g}}{\pi}$ & 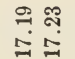 & $\begin{array}{l}\text { W } \\
0 \\
0\end{array}$ & \multirow{11}{*}{ 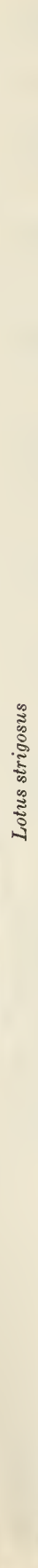 } & 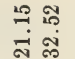 & 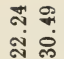 \\
\hline 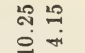 & 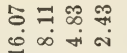 & & 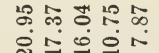 & $\begin{array}{l}20 \\
\text { in } \\
\text { in }\end{array}$ & 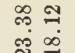 & శ్ণి & & 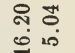 & :ึ ซึ \\
\hline 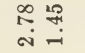 & 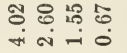 & & 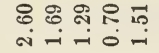 & $\stackrel{n}{0}$ & 点 & $\begin{array}{l}\infty \\
0 \\
0\end{array}$ & & 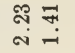 & $\stackrel{200}{\sim} \underset{\sim}{\sim}$ \\
\hline $\begin{array}{l}\text { a : } \\
\text { कొ } \\
0\end{array}$ & స్త్రి & & 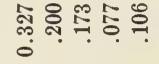 & 둥. & 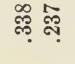 & శ్ఞి & & 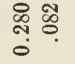 & 둥 \\
\hline 兽点 & 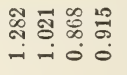 & & 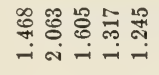 & $\stackrel{\substack{* \\
:}}{0}$ & 疍 & 趈 & & 苚 & 苛 \\
\hline$\hat{\infty} \vec{\sigma}$ & 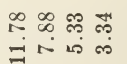 & & 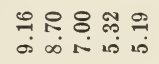 & ๙ึ. & 훔 & 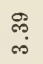 & & 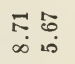 & సี \\
\hline $\begin{array}{l}\text { 유 } \\
0 \% 0 \\
0\end{array}$ & 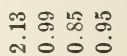 & & 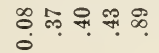 & 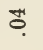 & ำ & $\stackrel{m}{:}$ & & ণึ? & $\stackrel{m}{\because}$ \\
\hline $\begin{array}{l}\text { Fi : } \\
\text { \& } \\
\text { in }\end{array}$ & 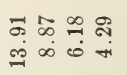 & & 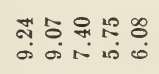 & $\underset{\infty}{\infty}$ & 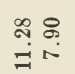 & $\begin{array}{l}\text { ஜొ } \\
\infty\end{array}$ & & $\begin{array}{l}5 \infty \\
5 \\
\infty \\
\infty\end{array}$ & mị \\
\hline 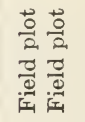 & 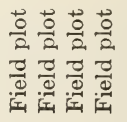 & & 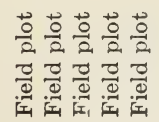 & 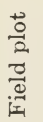 & 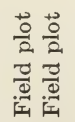 & 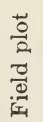 & & 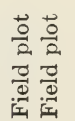 & 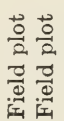 \\
\hline 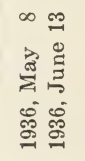 & 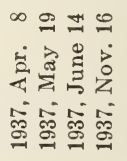 & & 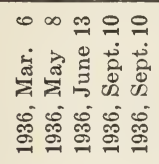 & $\begin{array}{l}0 \\
\dot{0} \\
z \\
\dot{0} \\
\ddot{्}\end{array}$ & 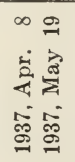 & 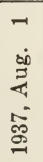 & & 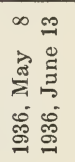 & 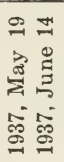 \\
\hline 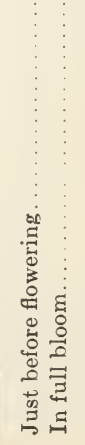 & 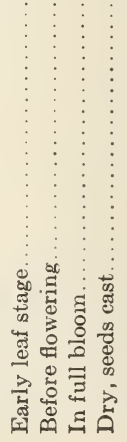 & & 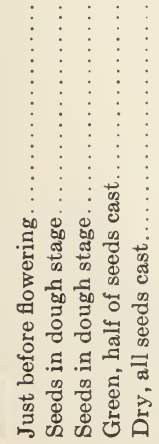 & 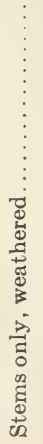 & 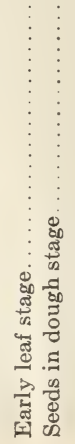 & 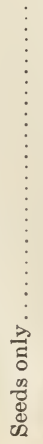 & & 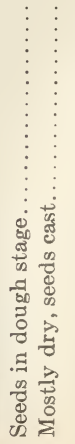 & 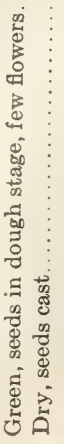 \\
\hline
\end{tabular}




\begin{tabular}{|c|c|c|c|c|c|c|c|c|c|}
\hline 苟这 & \multirow{11}{*}{ 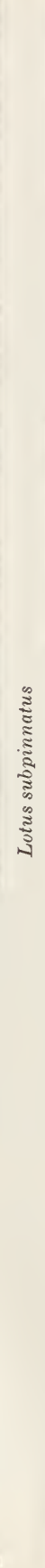 } & 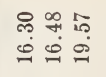 & 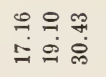 & $\begin{array}{l}\underset{\mathcal{P}}{\infty} \\
\stackrel{\infty}{\sim}\end{array}$ & 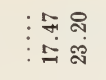 & \multirow{11}{*}{ 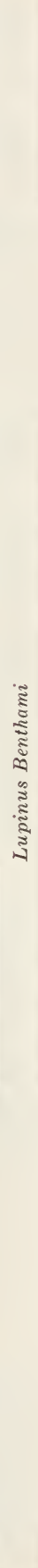 } & 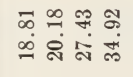 & 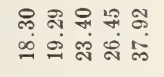 & 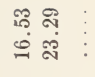 \\
\hline 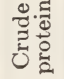 & & 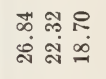 & 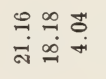 & $\begin{array}{l}\mathscr{\&} \\
\stackrel{-}{-1}\end{array}$ & 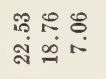 & & 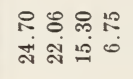 & 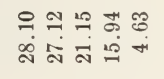 & 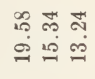 \\
\hline 施 & & 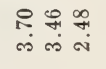 & 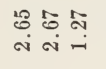 & 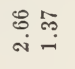 & 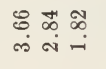 & & 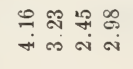 & 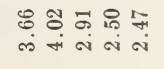 & 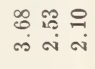 \\
\hline 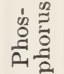 & & 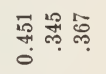 & స్థై స్థ & 苧 令 & 瓦 & & 留 & 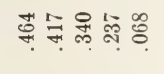 & 亦 \\
\hline שี & & 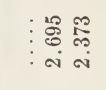 & 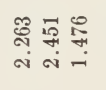 & 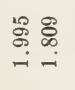 & 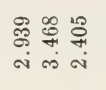 & & 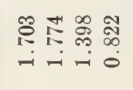 & 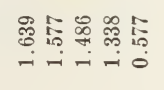 & 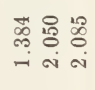 \\
\hline 帝 & & 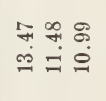 & 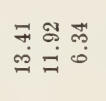 & 今ั? & 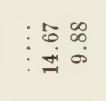 & & 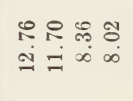 & 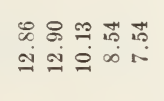 & 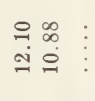 \\
\hline 茎 & & 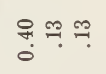 & సุ๋ ๆ จุ & $\stackrel{9}{?}$ & $\vdots \stackrel{n}{\infty}$ & & 웅유 & 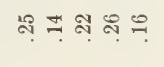 & $\because \frac{9}{0}$ \\
\hline 焉品 & & $\begin{array}{l}\infty \ddot{\Xi} \cong \\
\cong \beth \beth\end{array}$ & 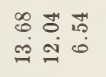 & $\begin{array}{l}\& 8 \\
\stackrel{9}{\circ}\end{array}$ & 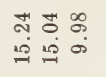 & & 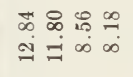 & 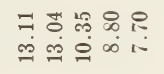 & 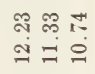 \\
\hline 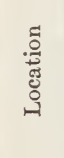 & & 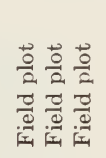 & 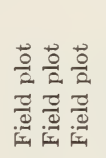 & 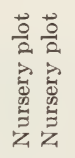 & 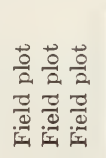 & & 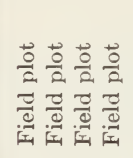 & 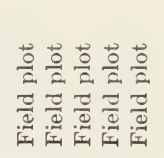 & 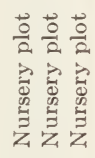 \\
\hline 宽 & & 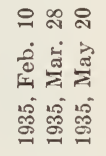 & 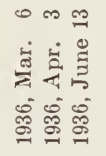 & 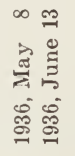 & 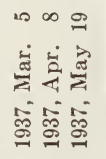 & & 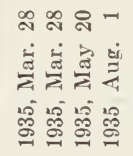 & 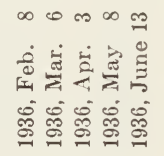 & 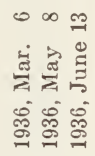 \\
\hline 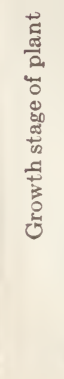 & & 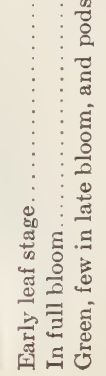 & 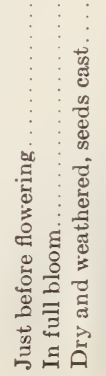 & 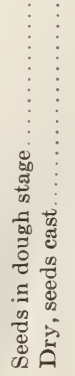 & 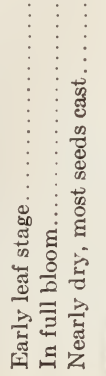 & & 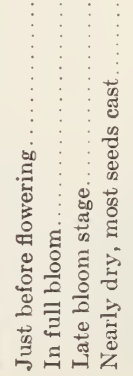 & 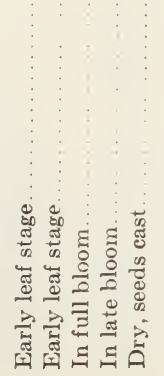 & 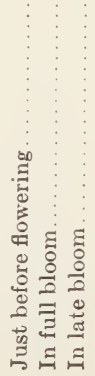 \\
\hline
\end{tabular}




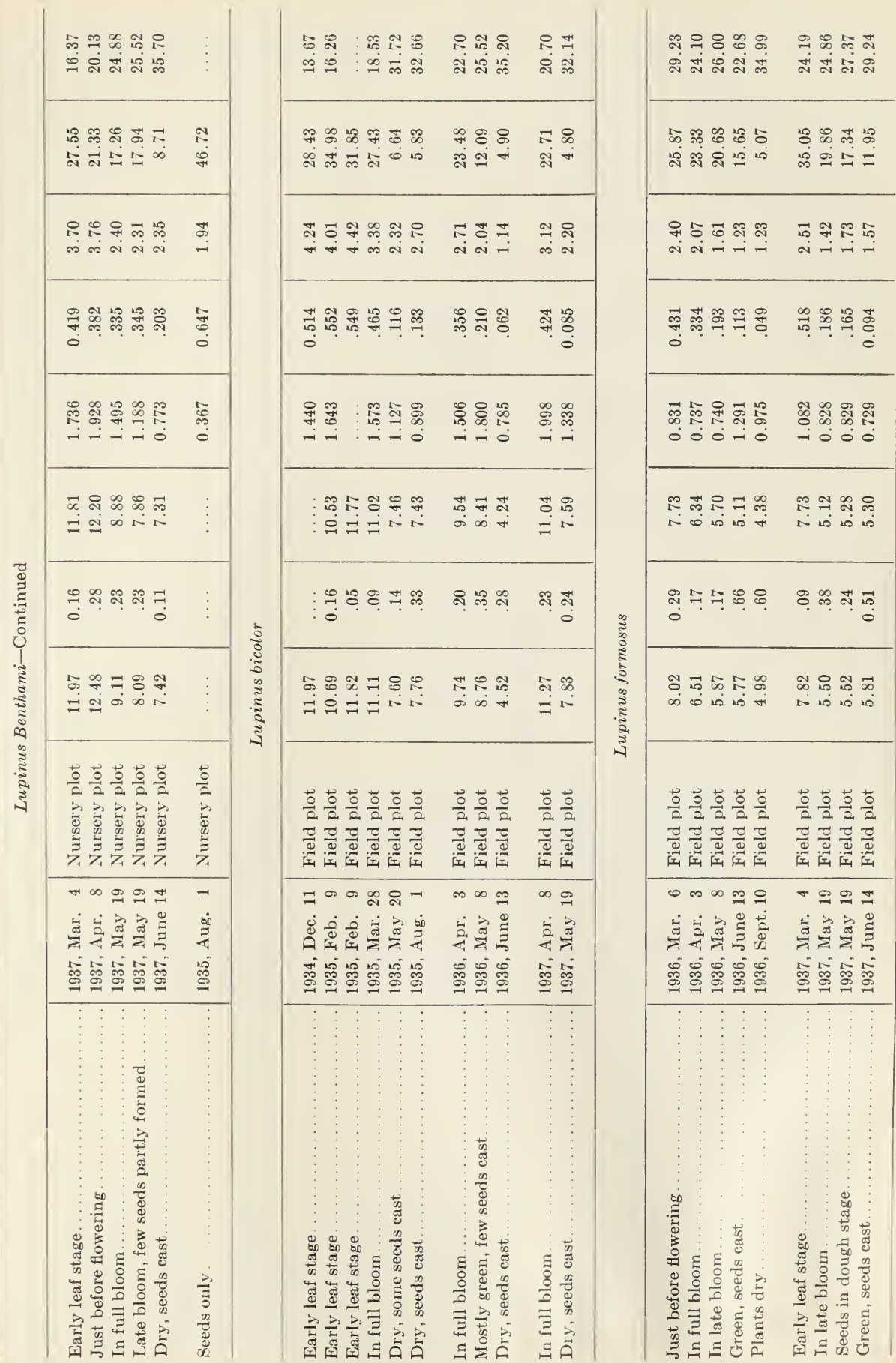




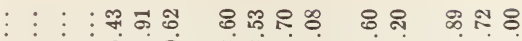

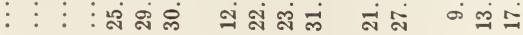

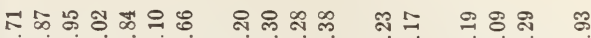

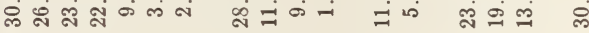

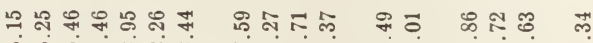
טंग

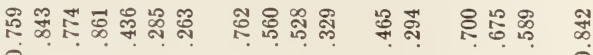

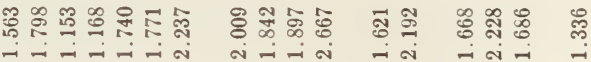

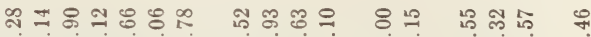
늠

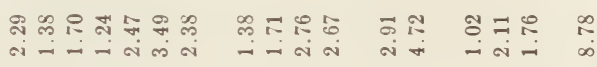

ผิ คี

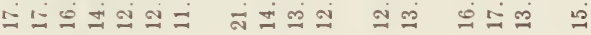

\begin{tabular}{|c|c|c|c|}
\hline 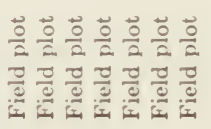 & 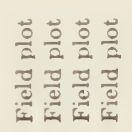 & 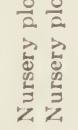 & 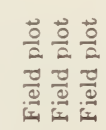 \\
\hline$\theta$ & $\infty 0$ & $\infty \infty$ & ஜ \\
\hline 5 & 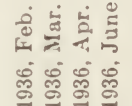 & 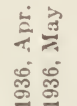 & 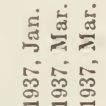 \\
\hline
\end{tabular}

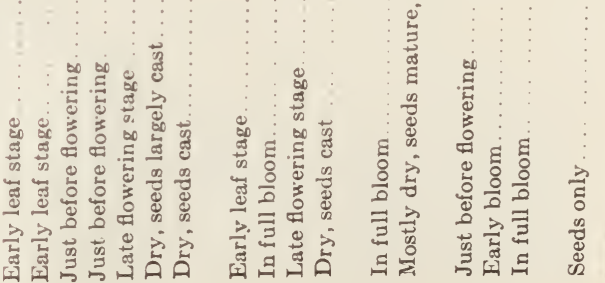




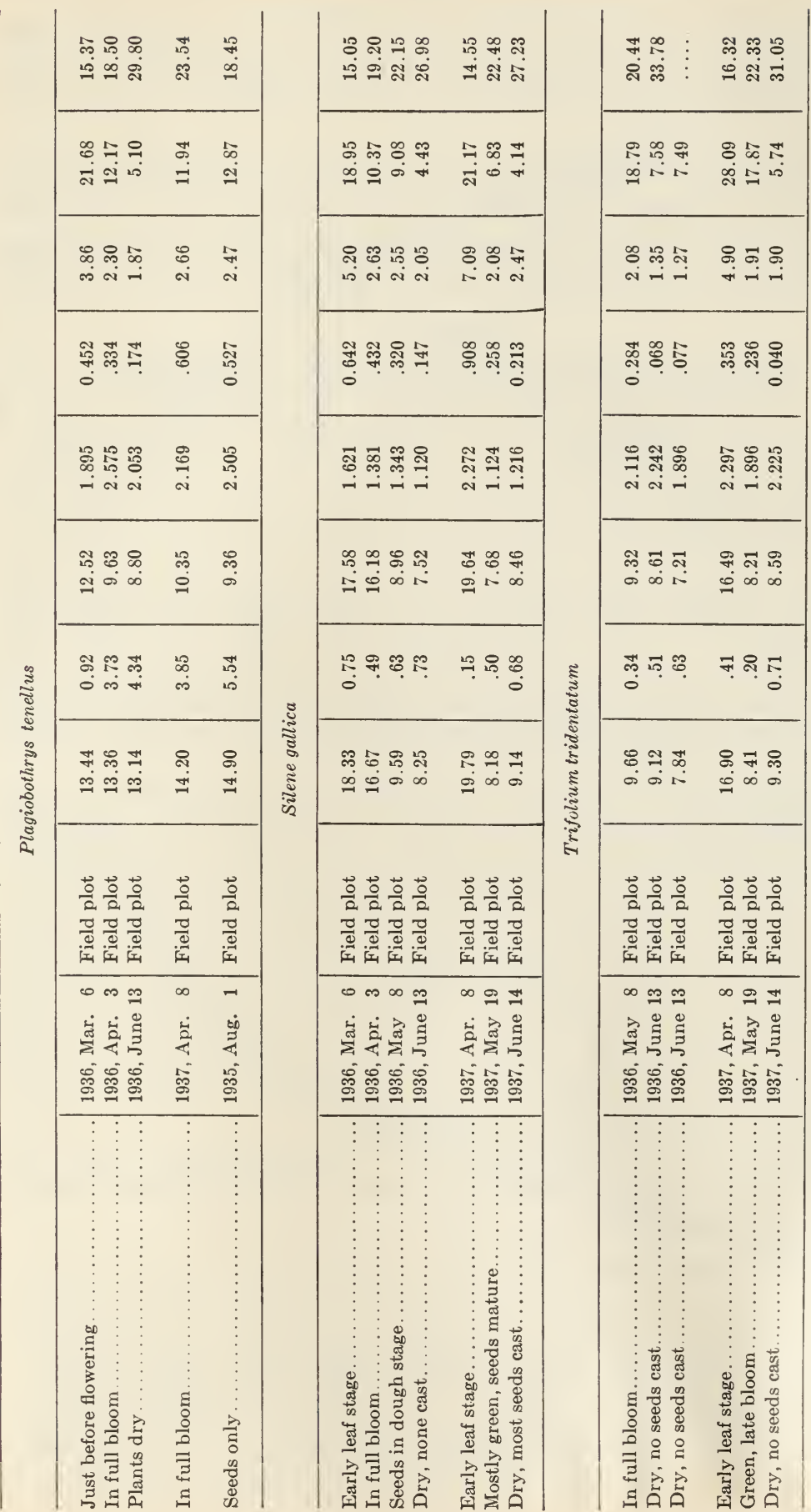


The seeds of this plant group are much richer in crude protein than are those of the grasses. This is especially true of Lupinus Benthami and Lotus americanus, whose seeds have a protein content in excess of 46 per cent.

In crude fiber the broad-leaved species show the expected behavior of relatively low content in the early growth period, and of maximum amounts at plant maturity. When the plant is young the percentage of growing tissue is relatively high and the cell walls are in a formative

\section{TABLE 6}

Vartation in Percentage of Crude Protein in Four Species of Broad-leaved Herbs for Three Successive Years*

\begin{tabular}{|c|c|c|c|c|c|c|c|c|c|}
\hline \multirow{2}{*}{ Species } & \multicolumn{3}{|c|}{ Early leaf stage } & \multicolumn{3}{|c|}{ Flowering stage } & \multicolumn{3}{|c|}{ Plant maturity } \\
\hline & 1935 & 1936 & 1937 & 1935 & 1936 & 1937 & 1935 & 1936 & 1937 \\
\hline Amsinckia & & & & & & & & & \\
\hline Douglasiana . & 23.95 & 22.71 & 23.43 & 10.63 & 13.85 & 10.61 & 4.20 & 4.29 & 4.95 \\
\hline Erodium botrys..... & 30.35 & 24.95 & $19.94 \dagger$ & $\ldots$ & 15.66 & 15.11 & 4.61 & 4.10 & 4.17 \\
\hline Hemizonia virgata & 26.20 & 22.94 & 21.61 & 6.59 & 6.49 & 6.92 & $\ldots$ & 5.30 & 5.32 \\
\hline Lupinus Benthami. & $\ldots \ldots$ & 27.61 & 27.55 & 22.06 & 21.15 & 17.26 & 6.75 & 4.63 & 8.71 \\
\hline
\end{tabular}

\footnotetext{
* In cases where more than one analysis was made of a given growth stage, the results were averaged.

$\dagger$ This low value may be accounted for by the fact that the first aerial growth of the scason was greatly slowed down for about a month by the abnormally low temperatures.
}

stage. At maturity the cell walls are lignified and the proportion of cellulose is high; this accounts for the high fiber content. In some species like Filago gallica, however, which build up high fiber content early in the growth eycle the stems constitute a large part of the total weight of the plant. In the same stage of growth for the three successive years of study the fiber content of a given species is much the same, indicating slight response of this constituent to environmental rariations (table 5). The range in crude fiber through the entire growth period is wide for any one species of this group, but it is relatively narrow in a given growth stage when the various species are compared.

In the seeds, the crude fiber content of this plant group ranges from approximately 7 to $19 \mathrm{per}$ cent. In the seeds of the leguminous species, however, the fiber content is very low.

Inorganic Constitucnts.-The rate of decline in the percentage of silica-free asl, and in potassium content, with respect to seasonal develment is typified in Amsinclia Douglasiana. The decline in these constituents from the early leaf stage to the late flowering period is rapid, as shown in segment $A B$ of figure 17 . From the late flowering period to maturity the level of the asl changes little, as seen in $B C$ of the figure. $\Lambda$ single analysis made at any point along the segment $A B$ is seen to be 

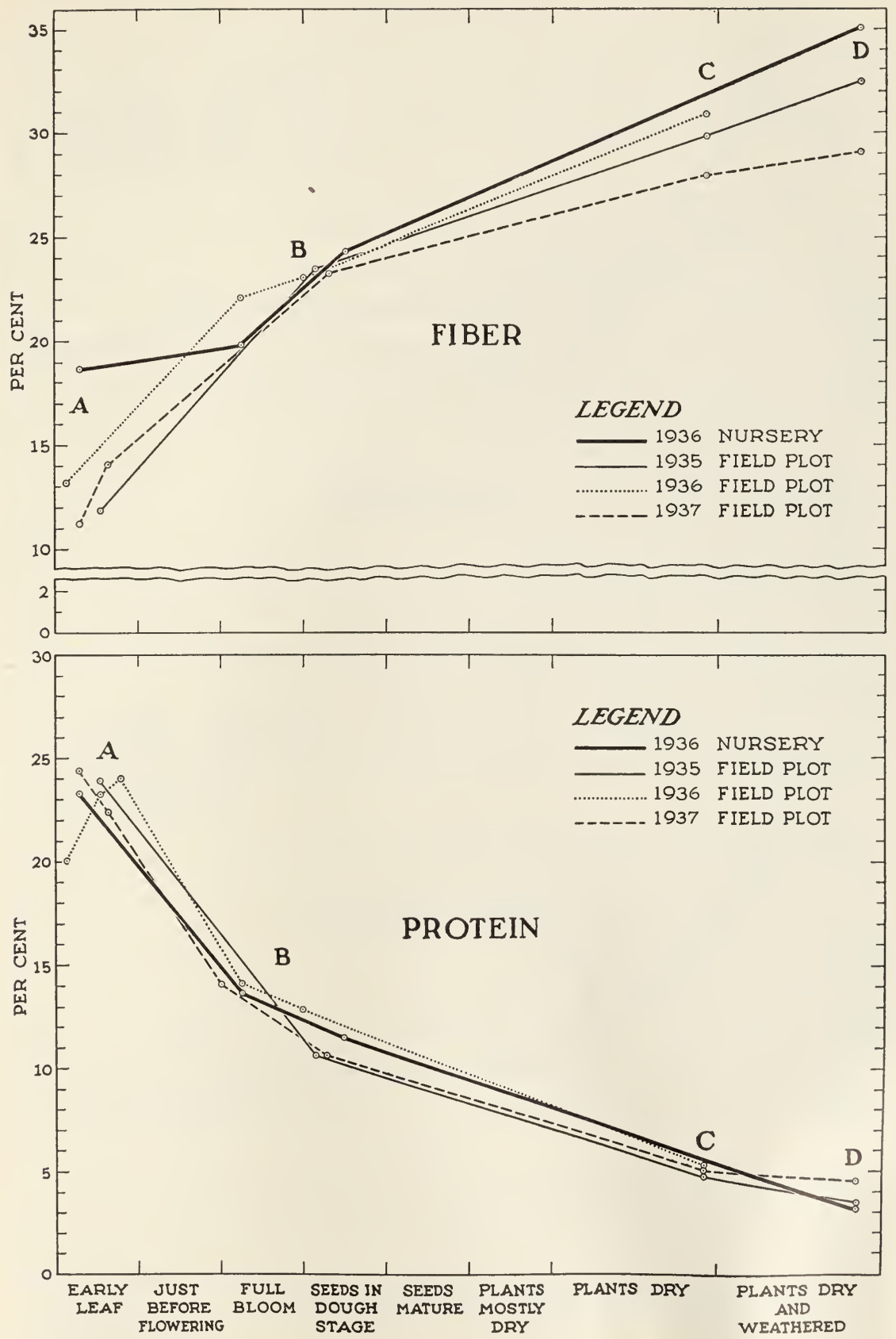

Fig. 16.-March of erude protein and erude fiber in Amsinckia Douglasiana for 1935, 1936, and 1937. 

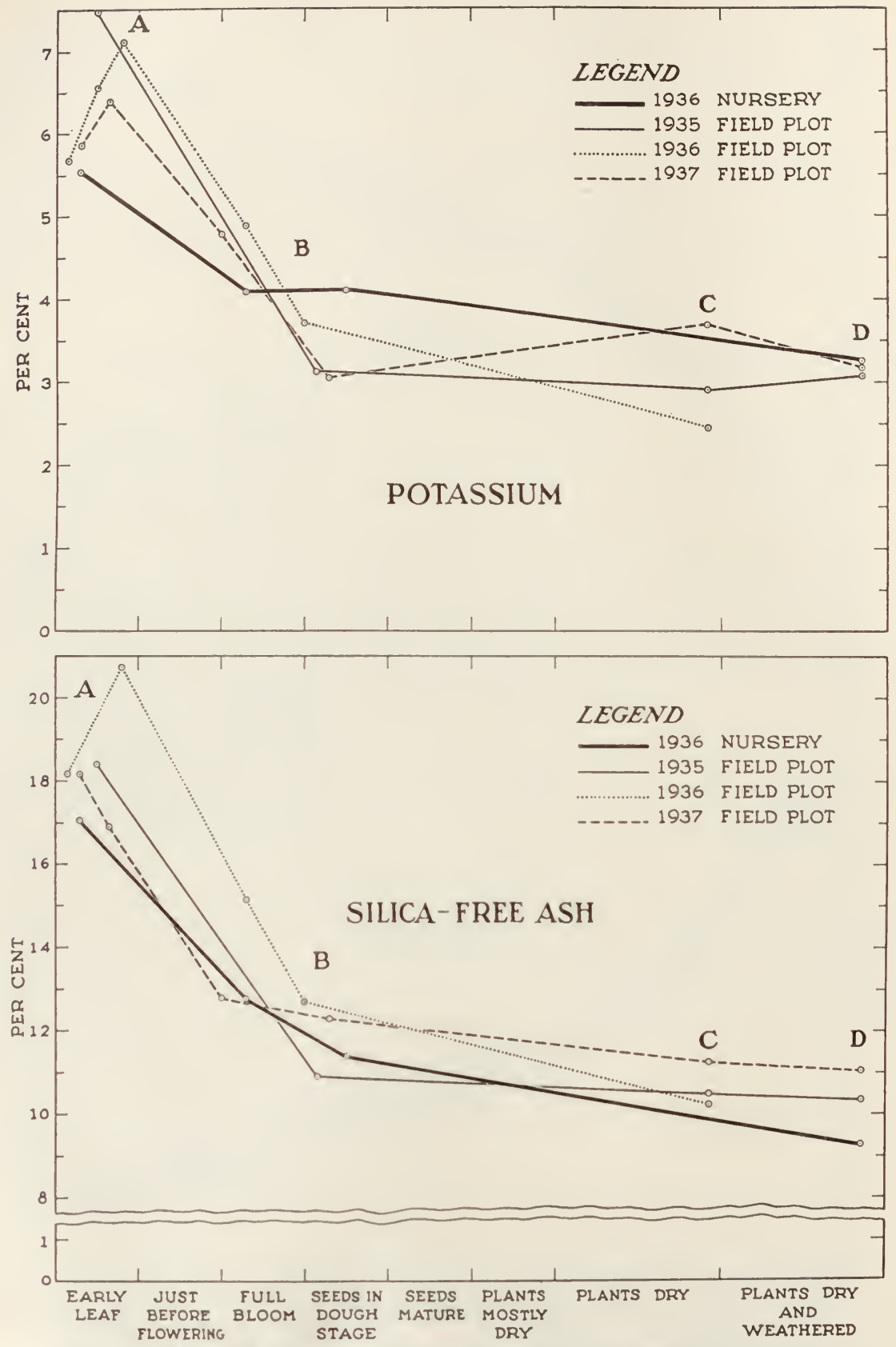

Fig. 17.-March of silica-free ash and potassium in Amsinckia Douglasiana for 1935,1936 , and 1937 . 
of little value in signifying the levels of these constituents for the early growth stages. On the other hand, a single analysis representing a sample characteristic of the segment represented by $B C$, gives a fairly reliable criterion of the ash and the potassium content of the plant from the flowering period to maturity.

There is wide variation among the percentages of silica-free ash in the various broad-leaved species at a given growth stage. Some species are consistently high in ash, whereas others are low in this constituent in the same developmental stage. Consistently high percentages of silicafree ash are found in the species of the borage family, among which Amsinckia Douglasiana and Plagiobothrys nothofulvus contain the highest amounts, the ash content accounting for nearly one-fifth of the moisture-free weight of these species when in the early leaf stage.

Although the levels of the silica-free ash vary among the different species, the percentages within a given species show still greater variation during the growth cycle. Thus in Lupinus Benthami and Hemizonia virgata, in 1936, the ash content declines 41.4 per cent and 69.0 per cent, respectively, from the earliest leaf stage to maturity. In Erodium cicutarium, on the other hand, the variation is relatively slight, being 14.49 per cent in the early leaf stage in 1935 , and 11.00 per cent at maturity in 1936. Of all the broad-leaved herbs investigated, the three species of Erodium show the least variation in ash content during the entire growing period.

Table 5 shows much consistency in the silica-free ash content within a species for any single growth stage, during the three years of study. Wide variation in the silica-free ash is recorded for the various species at the time of blossoming. The species which blossom early in the season, such as Erodium botrys, E. cicutarium, Lupinus bicolor, and Plagiobothrys nothofulvus, are high in silica-free ash at that stage ; those which blossom late, such as Hemizonia virgata, Lessingia germanorum, and Lotus americanus, are low in ash content when in the flowering period. Accordingly, late-blossoming species appear to be characterized by lower ash content in the later stages of vegetative growth.

The ash content in the seeds of the broad-leaved herbs is of a slightly lower level than that of the dry vegetative portion of the plant collected on the same date. The seeds of the leguminous species are the lowest in ash of this entire plant group, whereas those of Amsinckia Douglasiana, the three species of Erodium, and Plagiobothrys nothofulvus are the highest in this component.

The potassium content accounts for more than one-third of the silicafree ash in all the broad-leaved herbs. The maximum percentages are 
invariably found in the early leaf stage. In all species the levels of this element decrease from the early growth period to plant maturity. If the young seedling is regarded as the begimning of plant development, and maturity of the seed as the culmination of the life cycle, then the level of potassium decreases from initial growth and reaches the minimum in the fully developed seed.

In the early leaf stage Amsinckiana Douglasiana and Plagiobothrys nothofulvus contain the highest potassium content recorded in these studies. These are followed by Hemizonia virgata and Gilia tricolor, respectively, in the list of potassium-rich plants. The lowest potassium content recorded in the early leaf stage is in Lotus americanus, with 2.50 per cent, and in Lupinus formosus, with 2.51 per cent. From the early growth stage to full plant maturity the decline in potassium is somewhat more precipitous in species especially rich in this element than in those characterized by low potassium levels in the early leaf stage. In Plagiobothrys nothofulvus in 1936 there is a seasonal decline of 81.9 per cent. In contrast, in species of lower potassium content, such as Erodium botrys, there is a decline of 60.4 per cent through the season.

In the seeds the potassium content is low; in fact it is lower than in that of the mature, dry herbage, a reversal as compared with the phosphorus content. 'Thus in the seeds of Lupinus Benthami there is 1.94 per cent potassium, whereas the lowest content in the vegetative parts for the three years of investigation is 2.10 per cent. In the seeds of Amsinckia Douglasiana there is 1.35 per cent potassium, whereas in the regetative portion there is 2.45 per cent, this figure being the lowest recorded for this species.

The data show that there are conspicuously rich, as well as comparatively poor potassium plants among the broad-leaved species investigated. Since all of these species vary widely in potassium content through the growth cycle, recognition of their potassium level can only be known when analyses are made at several growth stages.

In calcium content the composition remains at nearly the same level throughout the life cycle in most of the broad-leaved species sampled in the regular field plots. Figure 18, which gives the seasonal trend of the calcium content in Amsinckia Douglasiana, shows that virtually the same level of this constituent is maintained from early leaf stage to maturity.

Shortening of the growing season appears to affect little the calcium content of the broad-leaved group of plants, as seen from samples procured in the nursery-planted species, which were seeded not less than 2 months after growth had started on the regular field plots. This point is typified in figure 18, where the percentages in calcium content for 

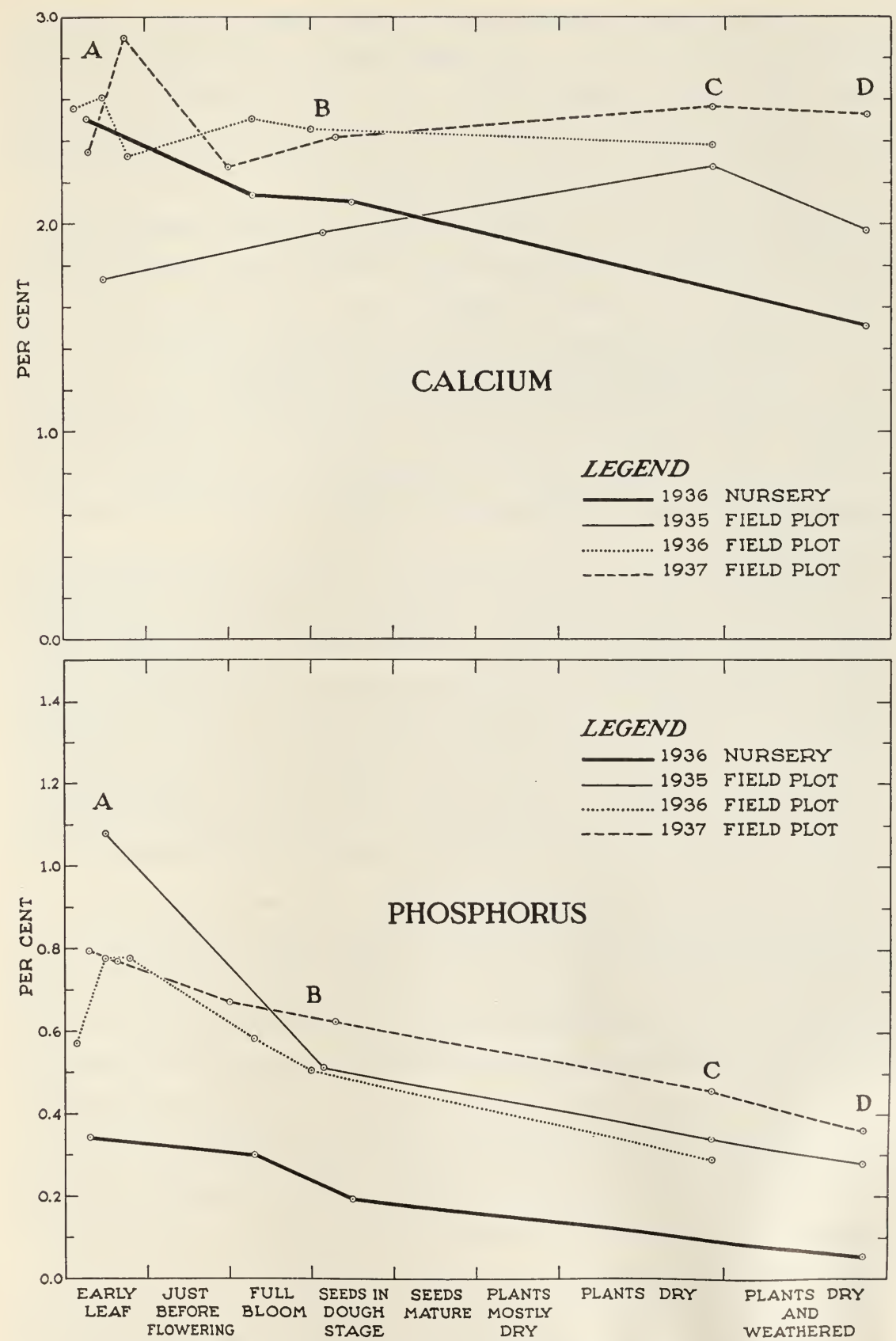

Fig. 18.-March of calcium and phosphorus in Amsinckia Douglasiana for 1935,1936 , and 1937 . 
Amsinckia Douglasiana, of the nursery-grown samples, are seen to differ but slightly in their values as compared with the field samples. Table 5 shows this tendency also to hold for the other nursery-grown broadleaved herbs. Samples representative of species grown near the Range Station headquarters on a deeper soil are of about the same calcium content as those collected on the regular field plot.

In phosphorus content the trend of the various species studied is represented by Amsinckia Douglasiana (fig. 18). There is a somewhat more rapid decrease in phosphorus from the early leaf stage until the late flowering period, designated as $A B$ on this graph. From the flowering: stage to maturity the decline continues, but at a less rapid rate. The phosphorus content in the nursery samples, as illustrated in figure 18, maintains the same general trend as in the regular field samples, but the absolute values are much lower. The apparent adverse effect of the shortened growing season on the levels of phosphorus holds for all nurserygrown species.

The phosphorus content in the broad-leaved species maintains the most orderly behavior of the minerals investigated. The minimum percentage is reached when the plants are dry and the seeds cast. The highest phosphorus content recorded for any growth stage of the broad-leaved species studied is 1.130 per cent, found in Gilia tricolor; whereas the lowest amount obtained is 0.040 per cent, in Trifolium tridentatum. When the extreme range in phosphorus content for a given growth stage is considered, for example the flowering period, the largest amount is 0.724 per cent, recorded for Erodium cicutarium, and the smallest amount is 0.128 per cent, recorded for Hemizonia virgata.

The members of the legume family, as seen in table 5 , are the lowest in phosphorus content of the broad-leaved herbs. This constituent is especially low at plant maturity for each of the six leguminous species. These figures bring out the fact that the same general behavior in the phosphorus content holds for the broad-leaved plant group, as in the grasses and grasslike species; namely, that the variation in phosphorus in a given species through the entire growing season is much greater than that in the various species for a specified growth stage. Obviously, therefore, determination of the phosphorus content only once or twice during the growing season may be of little value in evaluating the levels of this constituent in a range plant.

It is noteworthy that in nearly all the species the seeds contain a high percentage of phosphorus, and that the levels compare favorably with those of the very young leafage. In the seed of Plagiobothrys nothofulvus, for example, the phosphorus content is 0.842 per cent, and in the very 
young leafage it is 0.759 and 0.843 per cent. In Amsinckia Douglasiana there is a range between 0.766 and 0.878 per cent in the seed and 1.080 in the early leafage in 1935 . If the seed is regarded as the initial stage of plant development, the percentage of phosphorus decreases from the very initiation of life-cycle activities, beginning with seed germination, and continues downward until full maturity is reached.

The Calcium-Phosphorus Ratio.-In the broad-leaved herbs it has been shown that the calcium content remains at almost the same level through

TABLE 7

The Calcium-Phosphorus Ratio of Broad-leaved Herbs in the Early Growth Stage and at Maturity*

\begin{tabular}{|c|c|c|c|c|c|c|}
\hline \multirow[b]{2}{*}{ Species } & \multicolumn{2}{|c|}{1935} & \multicolumn{2}{|c|}{1936} & \multicolumn{2}{|c|}{1937} \\
\hline & $\begin{array}{c}\text { Early } \\
\text { leaf } \\
\text { stage }\end{array}$ & Maturity & $\begin{array}{c}\text { Early } \\
\text { leaf } \\
\text { stage }\end{array}$ & Maturity & $\begin{array}{c}\text { Early } \\
\text { leaf } \\
\text { stage }\end{array}$ & Maturity \\
\hline Amsinckia Douglasiana.......... & 1.6 & 6.8 & 3.5 & 8.1 & 3.4 & 6.2 \\
\hline Filago gallica................. & $\ldots$ & $\ldots$ & 2.8 & 4.9 & 2.7 & $\ldots$ \\
\hline Hemizonia virgata............... & 2.0 & $\ldots$ & 7.6 & 15.0 & 5.6 & 8.5 \\
\hline Lotus subpinnatus............... & $\ldots$ & $\ldots$ & $\ldots$ & 27.9 & 8.8 & 30.4 \\
\hline Trifolium tridentatum.......... & $\ldots$ & $\ldots$ & $\ldots$ & 24.7 & 6.5 & 55.6 \\
\hline Lupinus bicolor................ & 2.9 & 8.1 & $\ldots$ & 12.7 & $\ldots$ & 15.8 \\
\hline Lupinus Benthami............. & $\ldots$ & 6.1 & 3.7 & 8.5 & 4.1 & 3.8 \\
\hline Gilia tricolor.................... & 1.0 & 3.5 & 2.3 & 6.8 & $\ldots$ & 4.3 \\
\hline 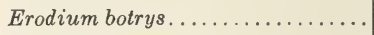 & 2.6 & 15.3 & 4.6 & 13.2 & 4.7 & 6.8 \\
\hline Erodium moschatum............ & $\ldots$ & $\ldots$ & $\ldots$ & 12.5 & 3.7 & $\ldots$ \\
\hline Erodium cicutarium.............. & 2.9 & $\ldots$ & $\ldots$ & 13.0 & 3.9 & $\ldots$ \\
\hline Silene gallica................. & $\ldots$ & .. & 2.5 & 7.6 & 2.5 & 5.7 \\
\hline Plagiobothrys nothofulvus........ & 2.1 & 6.2 & 2.6 & 8.1 & $\ldots$ & $\ldots$ \\
\hline Average..... & 2.2 & 7.7 & 3.7 & 12.5 & 4.6 & 15.2 \\
\hline
\end{tabular}

* In cases where more than one analysis was made of a given growth stage, the results were averaged.

the entire growth cycle, whereas the phosphorus content declines steadily, to reach the lowest level at plant maturity. This behavior results in a continuous widening in the calcium-phosphorus ratio with advancement of the season.

Table 7, compiled from table 5, shows that the calcium-phosphorus ratio is lowest in the early leaf stage, with an average range for the several species of 2.2 to 4.6 for samples taken on the regular field plots during the three years of study. At plant maturity the corresponding ratios are 7.7 and 15.2. This wide ratio at maturity is accounted for chiefly by the low phosphorus content. The calcium-phosphorus ratio is seen to vary widely in the species studied regardless of the stage of development.

Evaluation of the Species.-The broad-leaved species as a group, chemical composition alone considered, fall into two categories as applied to 
the economy of the range: (1) species having a short vegetative period, but which maintain a high level of protein and ash contents well into the late flowering stage; (2) those having a long vegetative period and characterized by a low level of ash and protein when the flowering period is reached. Erodium botrys affords an example of the first of these categories, and Hemizonia virgata, of the second group.

In Erodium botrys, from the early leaf stage to flowering, an interval of 4 weeks (from February 8 to March 6, 1936), the decline in crude protein is only 20 per cent. But from the flowering stage to maturity of the herbage, a period of 9 weeks, this constituent decreases nearly 75 per cent. In contrast, there is a decline in the late-blossoming IIemizonia virgata of 77 per cent from the early leaf stage to the time of flowering, a period of 27 weeks (March 6 to September 10, 1936), and of only 18 per cent from the flowering period to maturity, an interval of 8 weeks.

Table 5 shows that the ash, and some of its constituents, maintain approximately the same trends as do the protein. The relatively high nutrient content during a long vegetative period, however, enhances the value of palatable plants having late-flowering characteristics, despite the low values of the important constituents when the flowers appear.

The high protein content reported throughout the growth cycle for the palatable leguminous species, despite the short period between early growth and flowering, would appear to place the plants of this genus in a very favorable economic position.

The phosphorus content of this group, at plant maturity, however, is among the lowest of any of the herbs whose samples were collected in the regular field plots, the percentages being in the second decimal. It is noteworthy that of all the leguminous species studied, Lotus americanus and Lotus strigosus - the former very common on the foothill rangesare the lowest in ash and its various constituents at all the growth stages. Despite these apparent deficiencies in inorganic constituents, their relatively high yield of protein throughout the season places them among the most valuable of forage species as far as nutrients are concerned.

Of the species of the borage family, Amsinckia Douglasiana, Plagiobothrys nothofulvus, and Plagiobothrys tenellus, all of which are early maturing, maintain a high level of protein well into the late flowering stage, and of ash and its constituents until maturity. An exception is seen, however, as pointed out, in the collections taken from the lateplanted nursery plots, where the phosphorus content of the samples is low. Cryptantha flaccida, a species which has a long growing season, and which occurs commonly on depleted, thin soils in the locality studied, has the lowest percentage of protein and inorganic constituents at all growth 
stages of the four species of this family. Although most of these boraginaceous species here concerned are not of especially high palatability, they are generally high in nutritive values.

Among representatives of the geranium family, all of which mature early, Erodium cicutarium, as previously stated, has the highest content of protein and silica-free ash of the three species studied. Moreover, the high levels of all the constituents studied in this species are fairly well maintained to full maturity. Comparison of the three species when fully mature, as in 1936, shows a range in protein content of from 9.98 to 12.36 per cent for Erodium cicutarium, of from 3.36 to 4.84 per cent for $E$. botrys, and of 4.36 per cent for $E$. moschatum. The phosphorus content also is much the highest in Erodium cicutarium.

Table 5 shows that Erodium botrys and $E$. moschatum have nearly the same nutritive values. Collections of a divergent form of Erodium botrys, grown near the Station headquarters, in which a single plant composed each sample, were analyzed for comparison with material procured on the regular field plot. This divergent form is more robust, later maturing, has larger flowers, longer styles, and the inner sepals have a conspicuous red margin. Table 5 shows this form to be lower in all constituents, except in fiber, than the more typical forms of Erodium botrys. Possibly the form in question justifies its recognition as a variety.

Of the four species of the composite family, the late-maturing Hemizonia virgata, although of low palatability, is nutritionally superior because of the high levels of protein and minerals throughout the long vegetative period. Filago gallica and Lessingia germanorum, being low in protein and ash constituents, must be regarded as distinctly inferior species. Layia pentachaeta, although having a short vegetative span, at no time maintains a high level of the essential constituents. Even when very young, it approaches in composition the other inferior species of this family. The three above-named species are low in protein and ash at the growth periods when the other early-maturing species are still high in these constituents.

Gilia tricolor, another early-maturing plant, is characterized by ligh composition of protein, ash, phosphorus, and potassium. At maturity all constituents recorded, except fiber, reach relatively low levels. Navarretia viscidula, also a member of the gilia family, is similar in composition to that of Gilia tricolor, except that the phosphorus content is lower.

Godetia viminea and Godetia amoena, of the primrose family, are conspicuously low in all important constituents investigated except calcium. At maturity both species are very low in protein and ash.

Silene gallica, the only species studied of the pink family, is relatively 
low in protein in all growth stages, as compared with the other broadleaved species, but is fairly high in ash, with a satisfactory balance in essential mineral constituents.

\section{COMPOSITION OF BROWSE FROM SHRUBS AND TREES}

Since the foothill area investigated is of the open savanna-woodland type, browse vegetation contributes to the forage supply of the range at certain seasons, and presents a problem somewhat distinct from that of the life forms previously discussed. The nine species studied include deciduous and nondeciduous (evergreen) shrubs and trees of wide distribution. Because most of these species either mature late in the season or are green throughout the year, they supply important nutrients when the herbaceous vegetation is dry.

Table 8 gives the analytical data of the samples collected at various growth stages. The data are discussed separately for plants of the "halfshrub" type of the deciduous trees and shrubs, and of the nondeciduous shrubs.

Half-shrubs.-The samples of the two species of half-shrubs, characterized by semiherbaceous stems, namely, Lotus scoparius and Lupinus albifrons, contain both leaves and stems of the current growth. Since the proportion of these parts unavoidably varied in the different samples collected, the cyclic trends of the composition are somewhat irregular.

The crude protein content in the shoots of these two leguminous species decreases, and the crude fiber increases, from the early leaf stage to maturity. In Lupinus albifrons, however, the protein levels are consistently higher throughout the season, whereas the current growth of Lotus scoparius contains a lesser amount of crude fiber early in the season. The ash content, and the potassium and phosphorus of these species, decrease from the early leaf stage to maturity, whereas the calcium content shows no definite trend. Potassium comprises the highest percentage of the ash, followed by calcium and phosphorus respectively.

The leafage of the true woody deciduous shrubs and the trees-species whose stems are not green or herblike-differ from the species previously discussed, as seen in table 8, in the march of composition of several of the constituents. In this group the samples collected were of the same age and were collected approximately the same distance from the ground.

The protein levels decrease with maturity, whereas the fiber content follows no definite trend and is comparatively low. The ash and calcium contents increase uniformly from the early leaf stage to maturity, whereas the potassium and phosphorus contents decrease during this period. 
Compared with the other plant groups discussed, the protein content of the foliage in this group is very high in the early leaf stage, reaching nearly 40 per cent in some species. Even when the foliage is mature, the protein content is higher than in most of the species studied.

Table 8 shows that in the newly expanded flowers of Aesculus californica and Sambucus glauca, including the pedicels, the protein content is of the same level as that of the foliage for the corresponding period. As the flowers fade and the petals are dropping, however, the protein decreases much more rapidly than in the leaves.

The fruits of Aesculus californica, when in the dough stage, are nearly identical in protein content with the leaves collected on the same date, whereas this constituent in the fruits of Sambucus glauca is of much lower level than that in the leaves collected at the same time. The fruits (acorns) of Quercus Douglasii are conspicuously low in protein, a point of significance in view of their extensive utilization by foraging animals. The mature, hulled fruits contain only about 5 per cent protein, whereas the hulls, or shells, contain about 3 per cent-these figures being much the lowest of any of the fruits studied.

The crude fiber content of the leaves of the deciduous shrubs and trees is low, as stated; indeed, it varies little during the entire growth cycle. In Quercus Douglasii the maximum value in fiber for the three years of study is 17.50 per cent and the minimum, 11.50 ; whereas in Rhus diversiloba the values are 14.55 and 12.89 per cent. The flowers in Sambucus glauca are also low in fiber content, exhibiting much the same level as the leaves, whereas in the fruits this constituent is generally slightly higher than in the foliage. As would be expected, the hulls of the fruit of Quercus Douglasii have a high fiber content, whereas the naked, or hulled fruit, contains only from 4 to 6 per cent fiber. The young fruit of Aesculus californica, unhulled, contains 12 per cent.

The ash content in the foliage of the species of the true shrub-and-tree group exhibits a reverse ratio to that of most species previously discussed, being highest when the leaves are fully mature, and lowest in the early leaf stage. For example, in 1936, the silica-free ash content in Aesculus californica increases 178 per cent with the progression of the season, whereas in Sambucus glauca there is an increase of 65 per cent. The other species of this group show much the same relation.

The calcium content forms the largest single fraction of the ash constituents in the deciduous, woody plant group. There is an orderly increase in calcium throughout the leaf developmental period. In some species the percentage is exceedingly high at maturity of the foliage. In Aesculus californica, for example, the calcium increases more than 1,000 


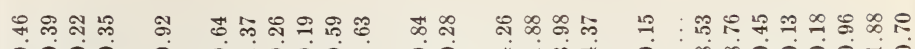

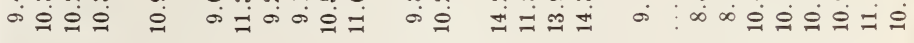

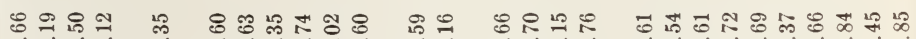

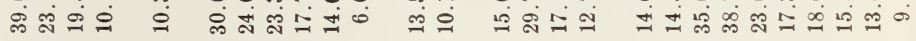

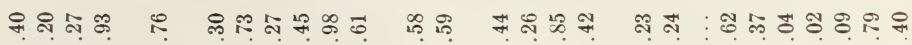
तबल
\end{abstract}

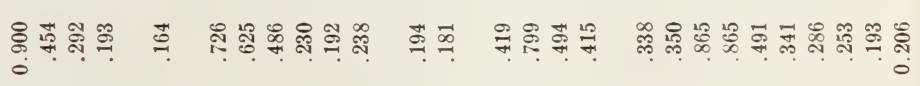

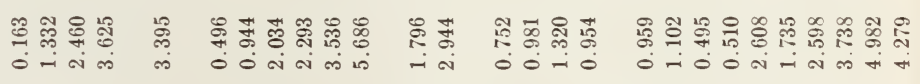

చ

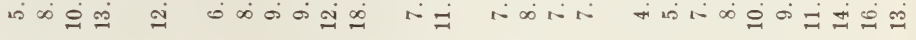

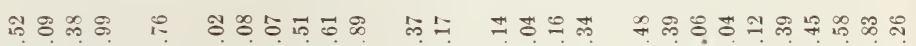
$000000000000-0000000000000-1$

๓ึ

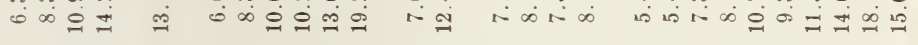

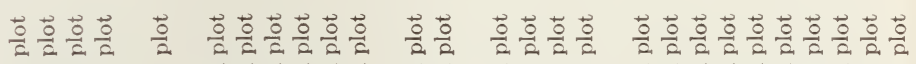

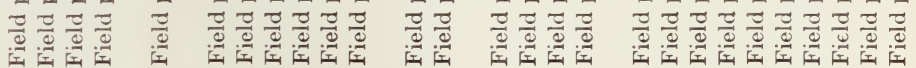

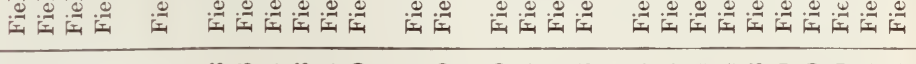

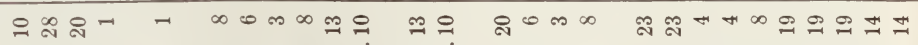

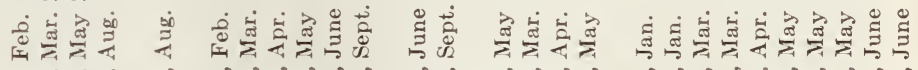

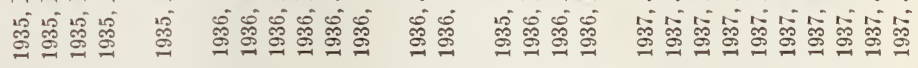

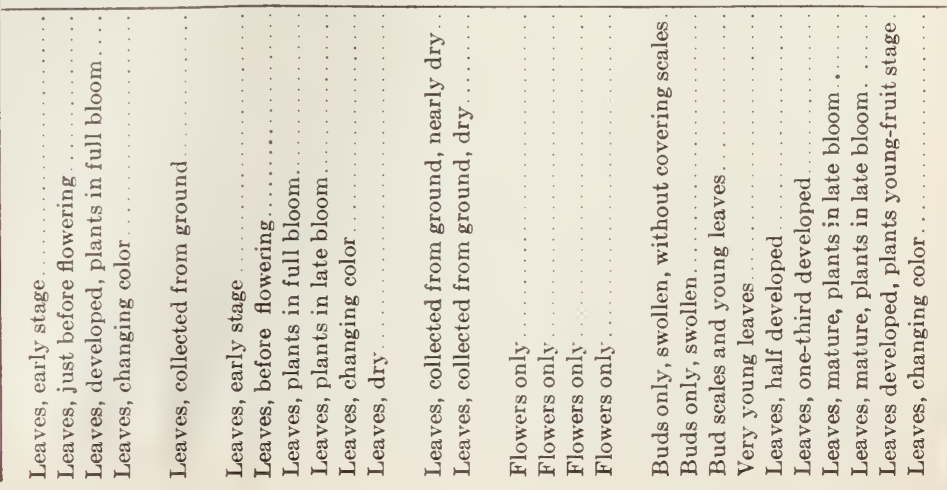




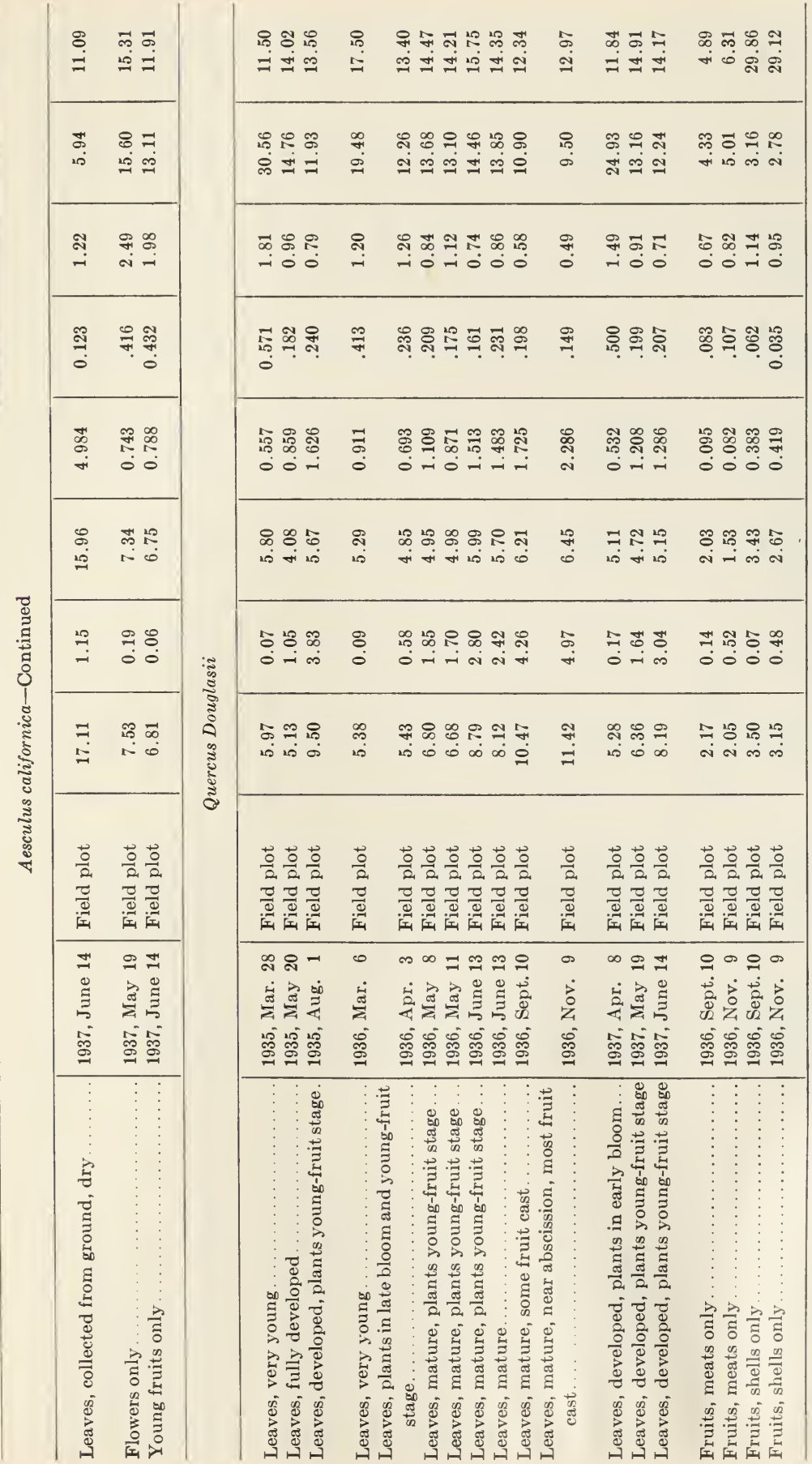




\begin{tabular}{|c|c|c|c|c|c|c|c|}
\hline 苞芯 & \multirow{11}{*}{ 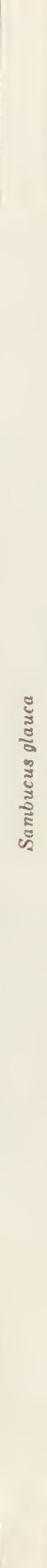 } & 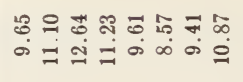 & 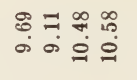 & 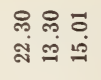 & 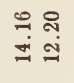 & 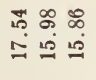 & $\begin{array}{l}8 \\
\dot{0}\end{array}$ \\
\hline 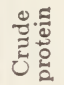 & & 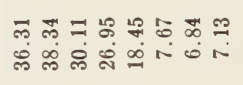 & 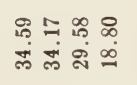 & 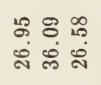 & $\begin{array}{l}\text { जे के } \\
\text { में ले }\end{array}$ & 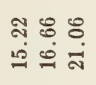 & $\stackrel{20}{20}$ \\
\hline 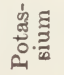 & & 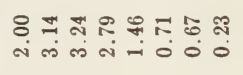 & 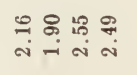 & 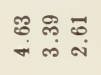 & 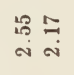 & 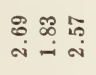 & $\stackrel{\vec{i}}{ }$ \\
\hline 要递 & & 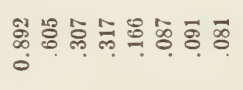 & 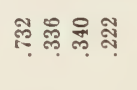 & \& & $\stackrel{200}{\exists}$ & 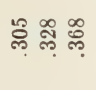 & 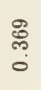 \\
\hline 竞 & & 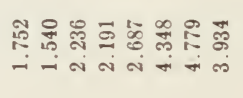 & 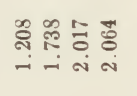 & 泀客家 & 蒙带 & 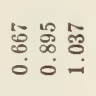 & $\begin{array}{l}\text { 웅 } \\
0\end{array}$ \\
\hline 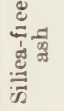 & & 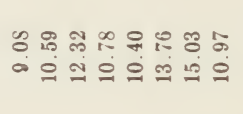 & 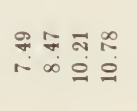 & $\begin{array}{l}\infty \text { 员 } \\
\stackrel{0}{=}=0 \\
=\end{array}$ & 은? & 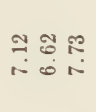 & ి్లి \\
\hline 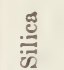 & & 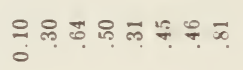 & 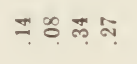 & "ㅇำ & శ్లి కె & \& ㅁํ & $\underset{\mathfrak{a}}{\mathfrak{0}}$ \\
\hline 푱표 & & 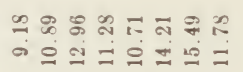 & 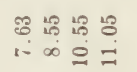 & 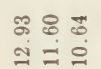 & 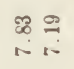 & 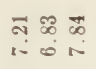 & 吕 \\
\hline 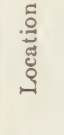 & & 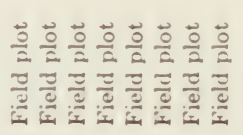 & 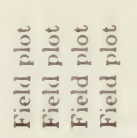 & 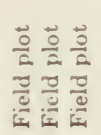 & 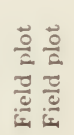 & 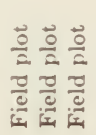 & $\frac{\overrightarrow{0}}{2}$ \\
\hline 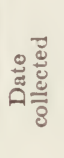 & & 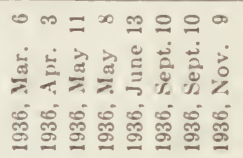 & 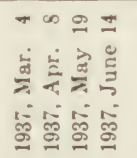 & 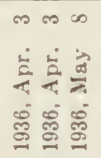 & 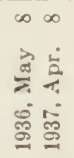 & 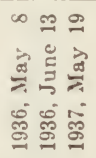 & 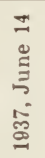 \\
\hline 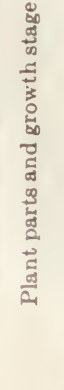 & & 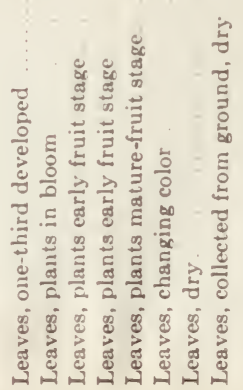 & 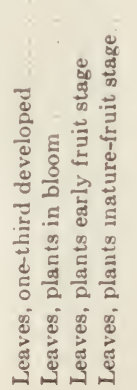 & 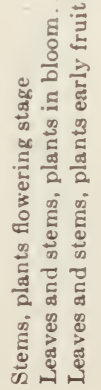 & 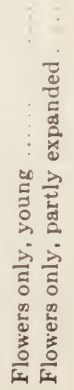 & 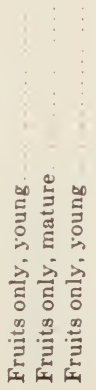 & 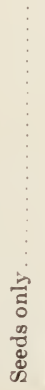 \\
\hline
\end{tabular}




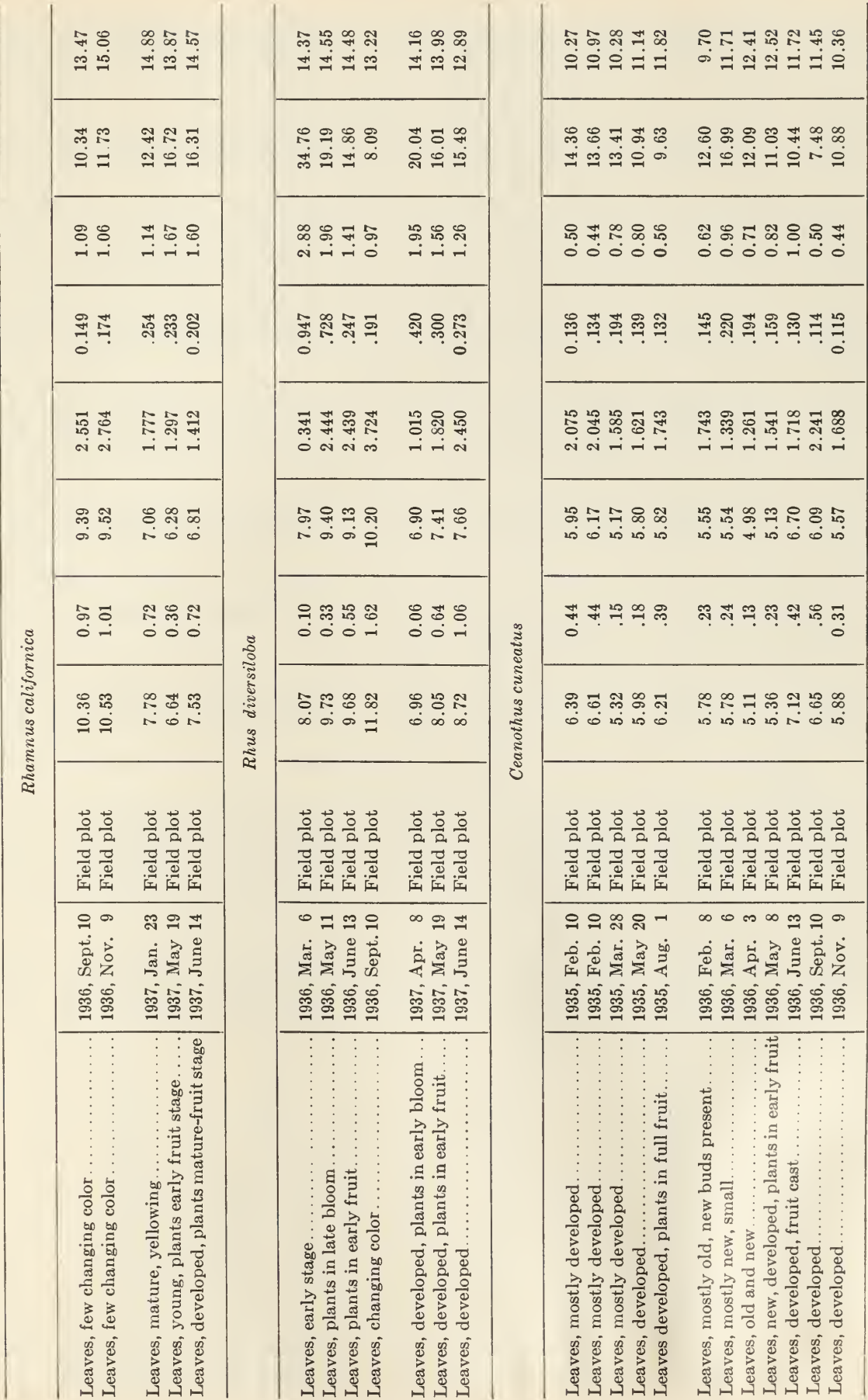




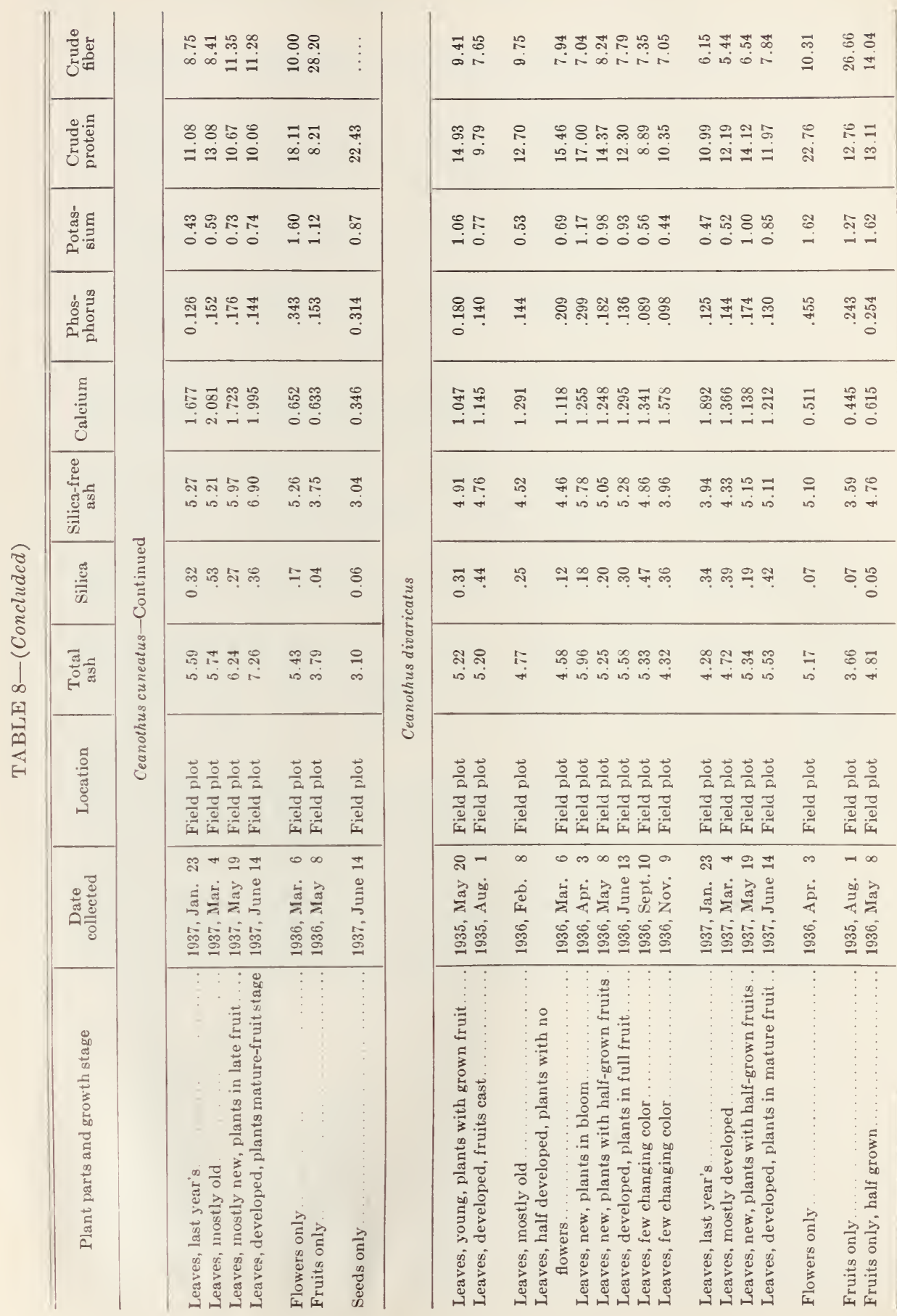


పี ๑

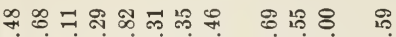

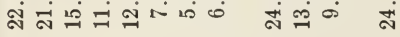

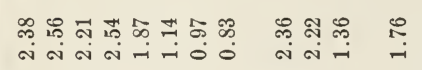

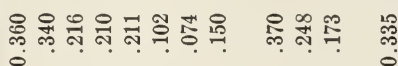

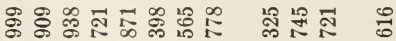
00000000 - 000

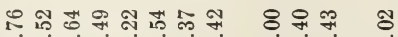

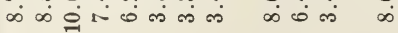

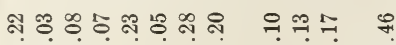

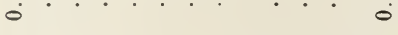

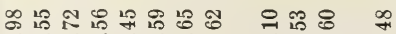

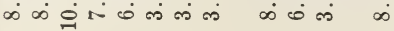

흥 흠 흥 흠

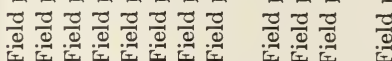

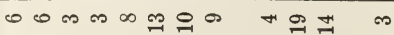

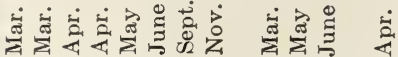

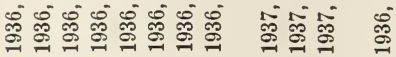

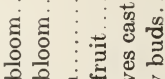
$\vec{\partial} \dot{0}=$ ङँ

I. $. \Xi . \Xi$

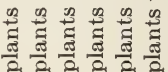
को

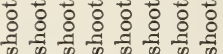

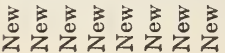

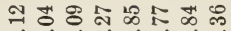

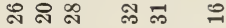

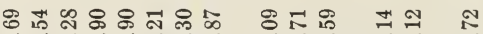

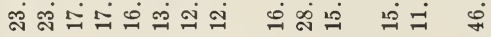

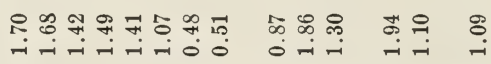

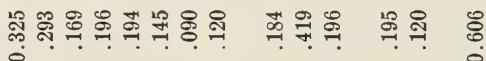

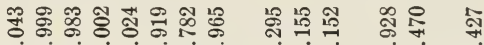
-i00-i்00 ri

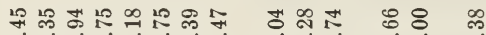

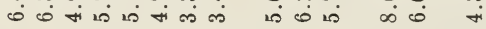

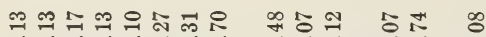

00000000 000

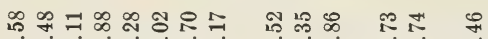

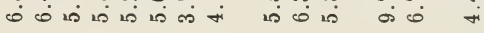

$\overrightarrow{0} \vec{*} \vec{*}+\overrightarrow{0}+\overrightarrow{0}+\overrightarrow{0}$

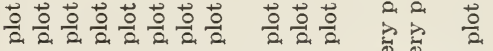

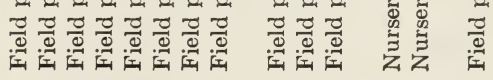

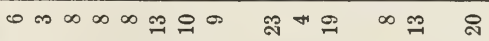

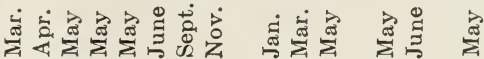

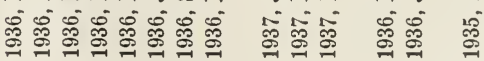

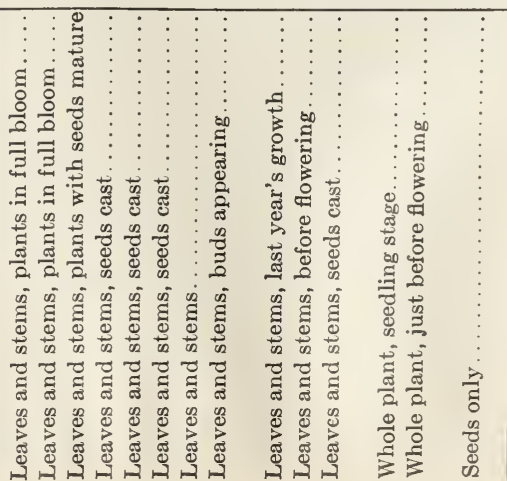


per cent from the time of unfolding of the leaves until they are mature and dry. In Sambucus glauca and Quercus Douglasii in 1936 there is an increase of 172 per cent and 151 per cent, respectively, for the corresponding period. In the flowers and the fruits the calcium content corresponds closely in values to that of the very young leafage.

The phosphorus content in the foliage is in reverse ratio to that of the calcium, being highest in the young leaf stage and lowest when the leaves are mature. Thus in Aesculus californica, in 1936, the phosphorus decreases 67 per cent during the growing season; in Quercus Douglasii and Sambucus glauca it decreases about 64 per cent and 90 per cent, respectively. In the young flowers the phosphorus content corresponds closely to that of the very young leafage; but as the flowers begin to fade this element assumes approximately the same level as that in the foliage collected on the same date.

The potassium content in the foliage of this plant group varies widely. Quercus Douglasii is notably low in this element, whereas in Aesculus californica, Sambucus glauca, and Rhus diversiloba, the potassium content is high. In all four species this constituent is much the highest in the early leaf stage, and declines in an orderly way to leaf maturity. The decrease, in 1936, amounts to about 30 per cent in Aesculus californica, 66 per cent in Rhus diversioloba, and 59 per cent in Quercus Douglasii. The young stems of Sambucus glauca, as seen in the samples collected in 1936, are higher in potassium than the foliage for the corresponding collection. The flowers and fruit of the species studied have approximately the same level of potassium as the foliage for the corresponding growth period.

Nondeciduous Spccies.-In the nondeciduous species the new leaves are interspersed with those produced the previous season. The composition of the samples here reported tends to vary but slightly throughout the growth cycle, because of the admixture of new and old leaves.

Table 8 brings out the fact that the crude protein content of the foliage of Ceanothus cuneatus and of $C$. divaricatus is low, ranging from about 17 per cent to 8 per cent. In both species the highest protein content is recorded when the proportion of young leafage is higher than the old in the sample. It is significant that the protein content of the foliage of the two species of Ccanothus is considerably higher from midsummer until late in the autumn than in that of most of the mature herbaceous species.

In the flowers of the two Ceanothus species protein is relatively high, whereas in the fruits it is low, being of the same magnitude as that of the leafage at the corresponding period. 
The crude fiber in the Ceanothus species is among the lowest of any plants here reported, ranging from 5.44 per cent to 12.52 per cent. The flowers contain nearly the same percentage of fiber as the leaves. In the mature fruit, however, this constituent is relatively high.

The silica-free ash content in the three nondeciduous shrubs is relatively low, Ceanothus divaricatus on the average being the lowest of this group, and Rhamnus californica the highest. No definite trend is shown in the ash content in these species through the season, presumably because of the mixed character of the samples, as explained.

The foliage of these shrubs contains more calcium than any other single mineral constituent. In the flowers and fruits of the Ceanothus species, however, the percentage of calcium clearly ranks second to that of potassium (table 8).

In potassium content Rhamnus californica is the highest and Ceanothus cuneatus is the lowest of the three nondeciduous species. In most of the samples of the Ceanothus species the percentage of potassium is in the first decimal, whereas in no instance does the calcium content fall below 1 per cent in the three species.

In phosphorus content the nondeciduous species, while not high at any stage of growth, is maintained at a fairly constant level. For the two species of Ceanothus the range for the three years of investigation is from 0.089 to 0.299 per cent. The flowers are richer in phosphorus than in any other plant organ reported.

The Calcium-Phosphorus Ratio.-In the deciduous shrubs and trees the calcium-phosphorus ratio increases with advancement of the season, being lowest in very young foliage and highest when the leaves are fully mature. The ratios for 1936 are shown in table 9, as derived from table 8 .

The data in table 9 are impressive of the fact that the calcium-phosphorus ratio is much the lowest in the early leaf stage and very high at leaf maturity. In Aesculus californica and Quercus Douglasii the rise in this ratio takes place largely after the flowering period. In the young leafage, when the meristematic tissue is proportionately large, and when cell division is actively taking place, the percentage of phosphorus is relatively high. But with advancement of age, and decline in the rate of growth, the percentage of phosphorus decreases in the foliar organs. Calcium, on the other hand, enters limitedly into meristematic activities, but is utilized much more extensively for cementing the cell walls in the older leaves with calcium pectate. Calcium also serves to neutralize the by-products of metabolism, hence the percentage of its content reaches the maximum when the foliage is mature.

In the nondeciduous group the calcium-phosphorus ratio varies greatly 
through the year. In Ceanothus cuneatus the ratio ranges between 6.1 in March, 1936, when the new leafage is partly formed, and reaches 19.7 in September, when the seeds are cast. In $C$. divaricatus the ratio ranges from 4.2 in April, when in the flowering stage, to 15.1 in January, 1937, before the new leaves are formed. In Rhammus californica the ratio ranges from 5.6 in May, 1937, in the early fruiting stage, to 17.1 in September, 1936, when growth is at a minimum.

In the deciduous half-shrubs the calcium-phosphorus ratio likewise is highest at the end of the growing season. In Lupinus albifrons, in 1936

TABLE 9

The Calcium-Phosphorus Ratio of Foliage of the Deciduous Shrubs and Trees at Three Growth Stages ; 1936

\begin{tabular}{|c|c|c|c|}
\hline Species & $\begin{array}{c}\text { Early leaf } \\
\text { stage }\end{array}$ & Full bloom & Maturity \\
\hline Aesculus californica........ & 0.7 & 4.2 & 23.9 \\
\hline Sambucus glauca..... & 2.0 & 2.5 & 50.7 \\
\hline Rhus diversiloba............ & 0.4 & 3.4 & 19.5 \\
\hline 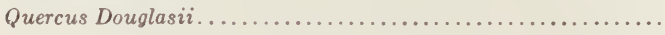 & 2.2 & $\ldots$ & 15.4 \\
\hline
\end{tabular}

in the field plot, this ratio ranges from 3.4 to 8.7. In Lotus scoparius the highest ratio is 7.6, recorded when the leaves are cast in September, 1936 ; and it is the lowest, namely 2.7 , before early bloom, in March of the same year.

Evaluation of the Species.-The woody species discussed fall into two categories in the matter of nutritional characteristics of the foliage, namely, those whose chemical values change but relatively little during the growing season, and those whose levels of the more important constituents change markedly during the growth cycle.

The nondeciduous shrubs, namely, Ceanothus cuneatus, C. divaricatus, and Rhamnus californica, typify the species of the first category. Although the levels of the organic and inorganic constituents of the foliage in these species are relatively low at all times, they are maintained throughout the year at more or less the same values. Because of the lower crude-fiber content, and the favorable balance of the more important nutrients, $C$. divaricatus outranks nutritionally $C$. cuneatus. $R$. californica, on the other hand, being somewhat higher in silica-free ash and in phosphorus than the two species of Ceanothus, appears to be the most desirable. Despite the fact that these three species are at no time especially high in protein, and in total ash and its constituents, they are nevertheless important on the range because of their succulence throughout the year. 
The species of the second group-those whose chemical values change markedly through the season, are all deciduous. The leaves of Aesculus californica and Sambucus glauca are the highest in silica-free ash, and especially in calcium at maturity, of the species in this group. Moreover, the foliage of $A$. californica increases greatly in sugars toward maturity, reaching 8 per cent when the leaves have dried, a factor which may account for its relatively high palatability late in the autumn. Quercus Douglasii has the lowest nutritional rank of the four species of this group. In silica-free ash this plant is considerably the lowest of the four species. The percentage of silica in these species increases markedly with advancement of the season, amounting in the mature leafage to nearly one-half of the ash content, a phenomenon which apparently accounts for the harshness of the foliage, and the fact that its palatability declines in the later growth stages. Moreover, the phosphorus, calcium, and potassium contents in Q. Douglasii are lower, whereas the fiber content is somewhat higher, than in the other three deciduous species. Rhus diversiloba is fairly high in nutrients throughout the season, and compares favorably in this respect with $A$. californica and S. glauca. All four species are of importance as browse because of their fairly high level of protein and essential inorganic constituents late in the season when the herbaceous cover generally is at its lowest nutritional ebb.

\section{COMPARATIVE LEVELS OF CONSTITUENTS IN THE SIX PLANT GROUPS}

Although the trends in composition of the samples of individual species have been shown, it is of interest to know whether the forage of all the species embraced in each of the various distinctive plant groups exhibits characteristic compositional trends and levels. For purpose of comparison three widely different growth stages were selected, namely, the early leaf developmental stage, the flowering stage, and the period of full maturity of the leafage. Graphic data have been prepared from averages of all the species of each of the six plant groups.

In deriving the points on the curves an average value for a given growth stage for each year was first obtained; then these curves for the three years were in turn averaged for each species; and the figures so derived were then averaged for each plant group. In the half-shrubs and the nondeciduous shrubs, however, because of the nature of their growth, the graph points were obtained by computing the averages for each species on a calendar basis for the three years, the month of March representing the initial point because of the abundance of early leafage at that 
time. Data on odd samples, such as flowers and seed, were not included in deriving these averages.

Figure 19 shows that the deciduous shrubs and trees are much the highest of the groups in the percentage of crude protein at the early leaf stage, and also at the time of flowering. Moreover, a relatively high protein level is maintained in this group at maturity. The broad-leaved herbs rank second in protein content in the early leaf stage and in the blossoming period, but the grasses and grasslike species show only slightly lower levels than the broad-leaved herbs throughout the growth cycle. The halfshrubs are high in protein content in March, followed by a sharp decline, which reaches the minimum level late in the summer, after which there is a continuous rise, giving the curve the appearance of a circular segment. The nondeciduous species maintain a more constant level of protein throughout the growth cycle in the mixed foliage, being the lowest of all the groups early in the season, but second highest late in the autumn.

In crude fiber (fig. 20), the half-shrubs are the highest from late spring until late summer, when, because of a larger proportion of leafage on the shoots, the fiber content decreases. The grasses and the grasslike species, which have nearly the same values, outrank all the other groups in this constituent, except the half-shrubs, for a part of the season, as pointed out. Next to the grasses, the grasslike plants, the broad-leaved herbs, the deciduous shrubs and trees, and the nondeciduous shrubs, respectively, rank in the fiber levels in the order named. The range in values in these groups is large. The nondeciduous shrubs and the deciduous shrubs and trees rum parallel in this constituent throughout the season; they vary little in values, and are conspicuously lower than the other groups.

The silica-free ash (fig. 21), is highest in the broad-leaved herbs of the six groups until midsummer, when the deciduous shrubs and trees take the lead. The grasses and the grasslike species maintain nearly the same level in ash content, but they are distinctly lower than the broadleaved herbs. The deciduous shrubs and trees are relatively low in ash in the early leaf stage; but the rise continues gradually throughout the season, reaching the highest point of all the groups late in the autumn. The half-shrubs and the nondeciduous shrubs form irregular curves of ash values, the crests and depressions of which are evidently determined by the proportion of new and old leaves contained in the samples. The highest crest of the ash level in the half-shrubs comes in the late summer, whereas that in the nondeciduous shrubs is recorded in early spring.

The calcium content varies widely in the different plant groups. The broad-leaved herbs lead in this constituent in the early leaf stage (fig. 22). Fairly early in the season, however, the deciduous shrubs and trees, fol- 


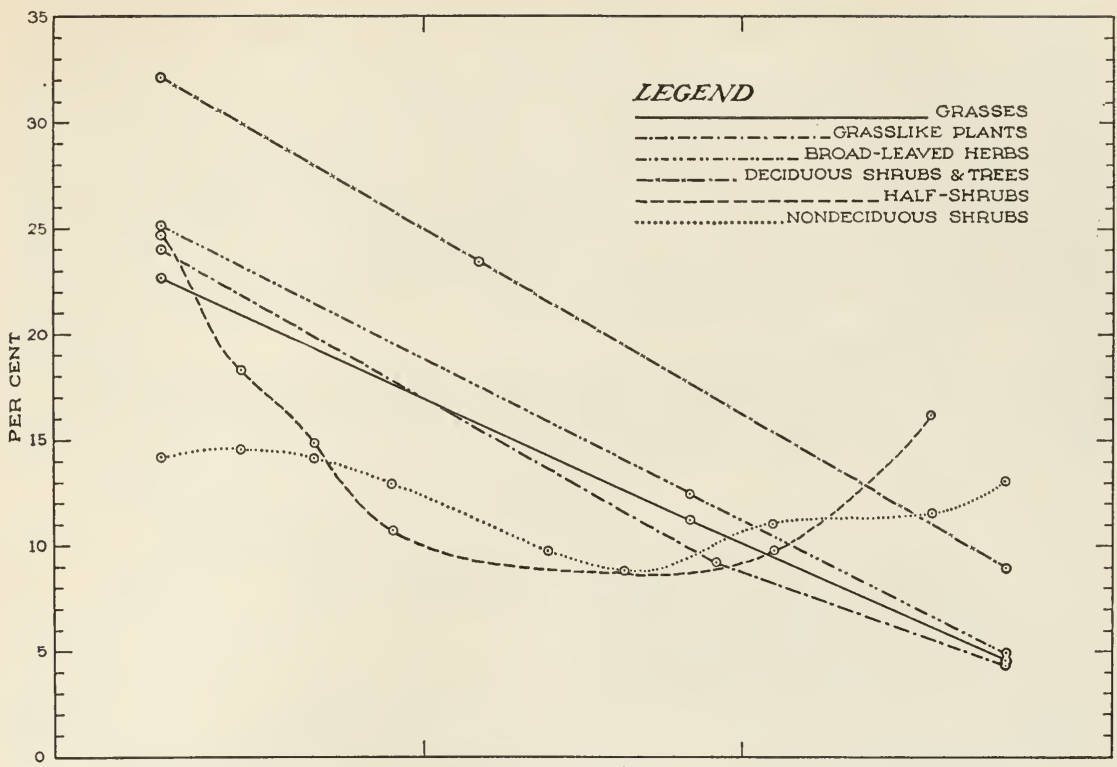

EARLY LEAF

Fig. 19.-March of crude protein in the six plant groups.

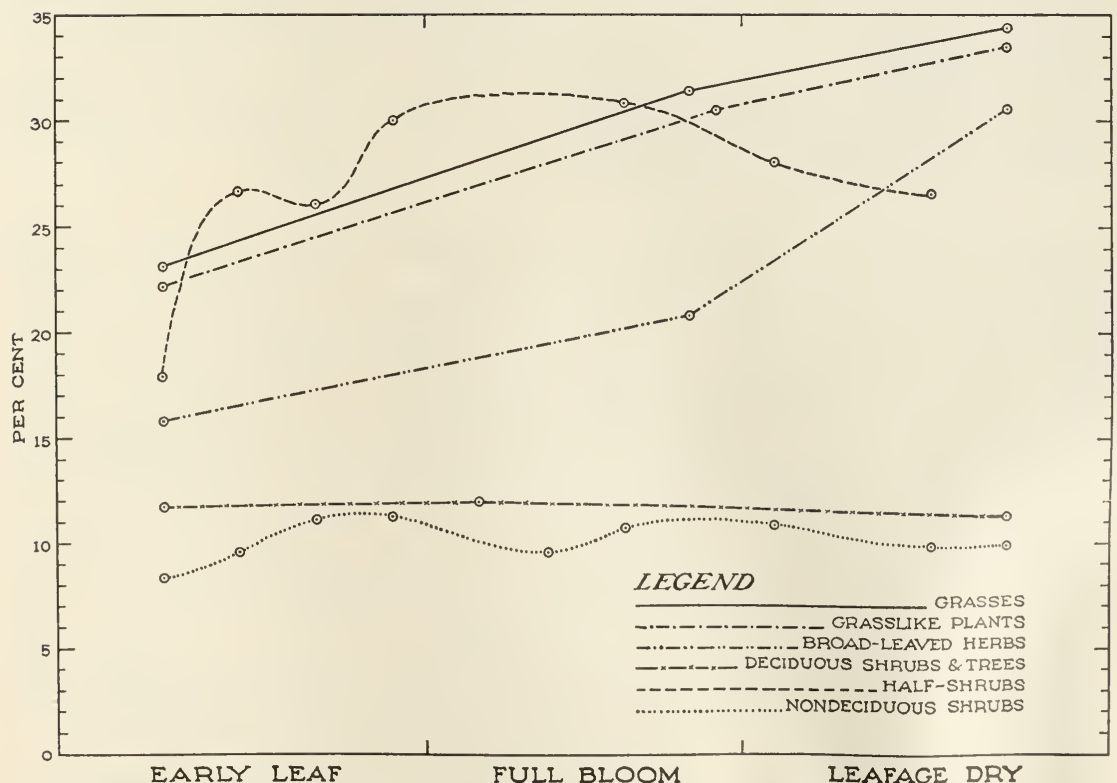

Fig. 20.-March of crude fiber in the six plant groups. 


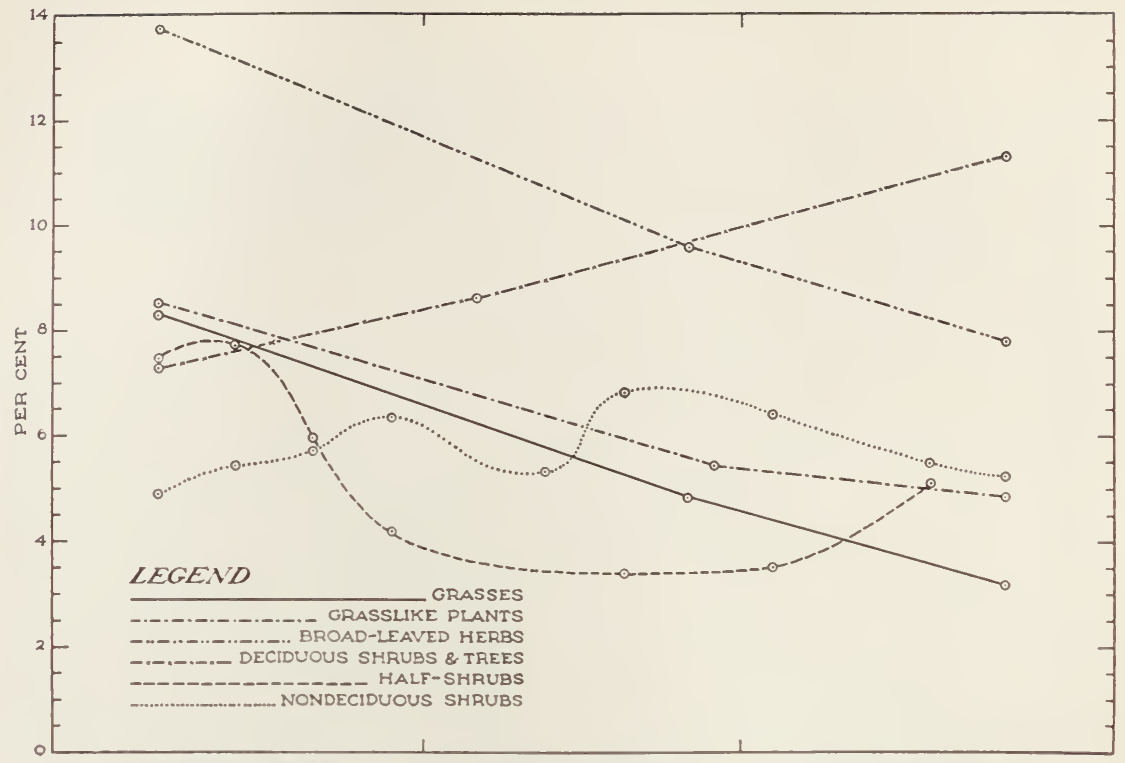

EARLY LEAF FULL BLOOM LEAFAGE DRY

Fig. 21.-March of silica-free ash in the six plant groups.

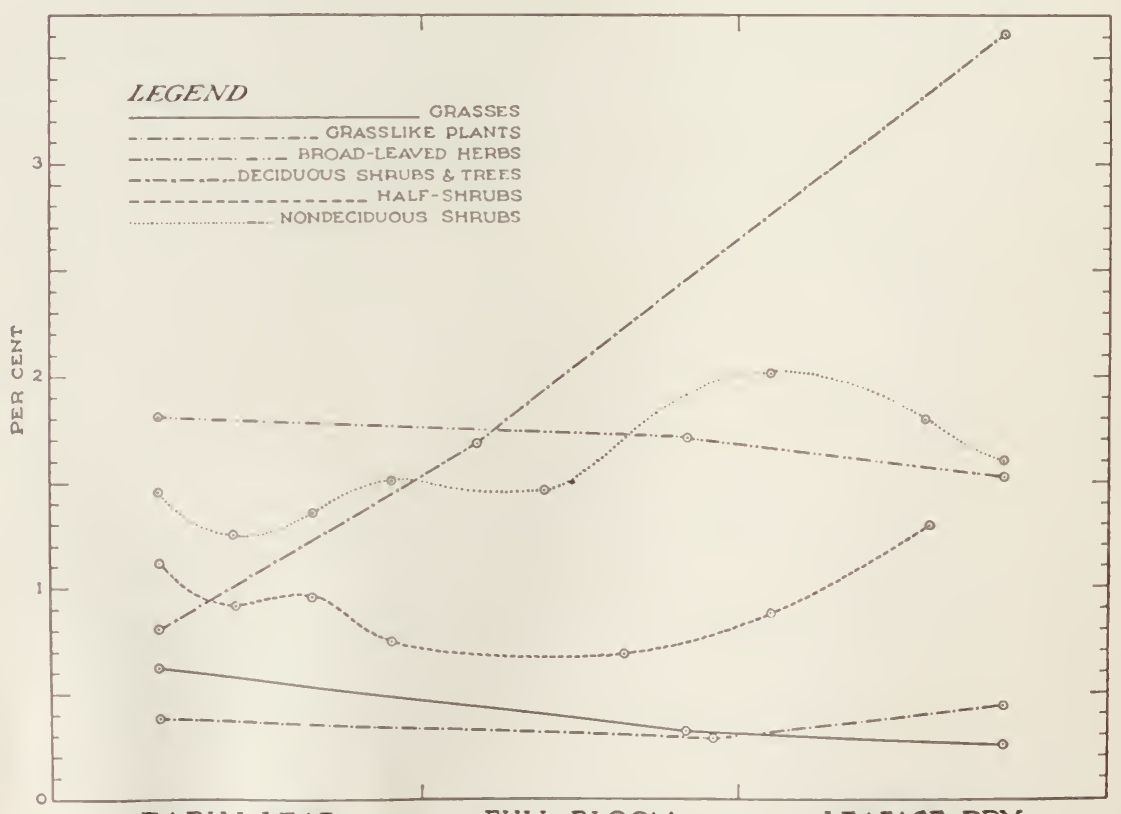

EARLY LEAF

Fig. 22.-March of calcium in the six plant groups. 
lowed by the nondeciduous shrubs, exceed the broad-leaved herbs in this constituent. At maturity the deciduous shrubs and trees far outrank all other groups in the percentage of calcium. The grasslike species are the lowest in this constituent, followed closely by the grasses. The halfshrubs and the nondeciduous shrubs form irregular curves, reaching the maximum calcium values in the autumn. The nondeciduous shrubs rank second in calcium levels from early summer until the following growth period.

In phosphorus the range in the early leaf stage is clearly the widest of the three ash constituents studied, and it is the narrowest at leaf matu-

TABLE 10

Trends of the Various Constituents in the Plant Groups, From the EARLy Leaf Stage to Maturity

\begin{tabular}{|c|c|c|c|c|c|c|}
\hline Plant groups & Ash & Calcium & Phosphorus & Potassium & Protein & Fiber \\
\hline Grasses. . & Decrease & Decrease & Decrease & Decrease & Decrease & Increase \\
\hline Grasslike plants...... & Decrease & $\begin{array}{c}\text { Level varies } \\
\text { slightly }\end{array}$ & Decrease & $\begin{array}{c}\text { Level varies } \\
\text { slightly }\end{array}$ & Decrease & Increase \\
\hline Broad-leaved herbs... & Decrease & $\begin{array}{c}\text { Level varies } \\
\text { slightly }\end{array}$ & Decrease & Decrease & Decrease & Increase \\
\hline $\begin{array}{l}\text { Deciduous half- } \\
\text { shrubs............ }\end{array}$ & Decrease & $\begin{array}{c}\text { Level varies } \\
\text { slightly }\end{array}$ & Decrease & Decrease & Decrease & Increase \\
\hline $\begin{array}{l}\text { Nondeciduous shrubs } \\
\text { Deciduous trees and } \\
\text { shrubs............. }\end{array}$ & 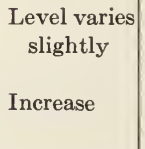 & 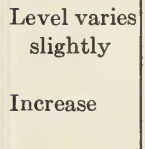 & $\begin{array}{c}\text { Level varies } \\
\text { slightly } \\
\text { Decrease }\end{array}$ & $\begin{array}{c}\text { Level varies } \\
\text { slightly } \\
\text { Decrease }\end{array}$ & $\begin{array}{c}\begin{array}{c}\text { Level varies } \\
\text { slightly }\end{array} \\
\text { Decrease }\end{array}$ & $\begin{array}{l}\text { Level varies } \\
\text { slightly } \\
\text { Level varies } \\
\text { slightly }\end{array}$ \\
\hline
\end{tabular}

rity, as shown in figure 23. The deciduous shrubs and trees are much the highest in phosphorus content in the early leaf stage, and the nondeciduous shrubs and the half-shrubs are the lowest throughout the season. In the broad-leaved herbs, the grasses, and the grasslike groups, the phosphorus values are nearly parallel in their decline throughout the season, the first-named being the highest and the grasslike species the lowest.

In potassium content (fig. 24) the broad-leaved herbs rank first, followed by the grasslike species, the grasses, the deciduous shrubs and trees, the half-shrubs, and the nondeciduous species, in the order named. The range in potassium content in the various plant groups is wide throughout the season, and conspicuously so early in the growth period.

The comparative study of the six plant groups brings out several points of contrast, namely: (1) the levels of the various constituents differ widely throughout the season in the respective plant groups; (2) in protein and phosphorus the range in the levels is highest in the early leaf 


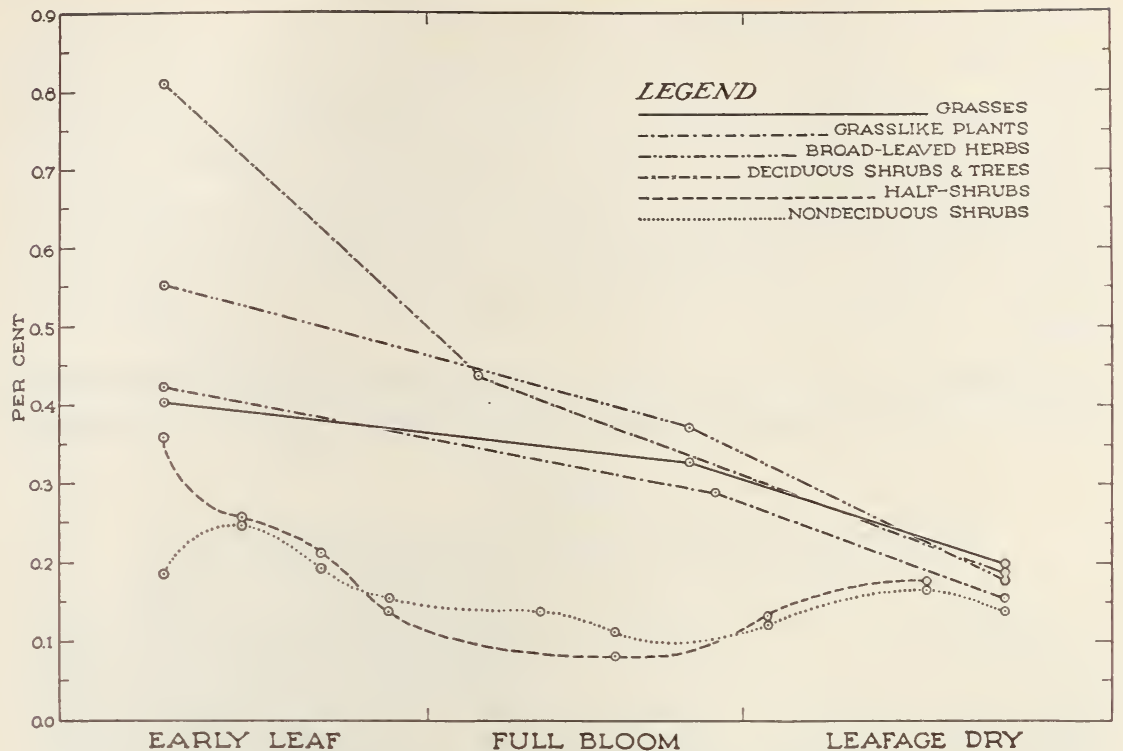

Fig. 23.-March of phosphorus in the six plant groups.

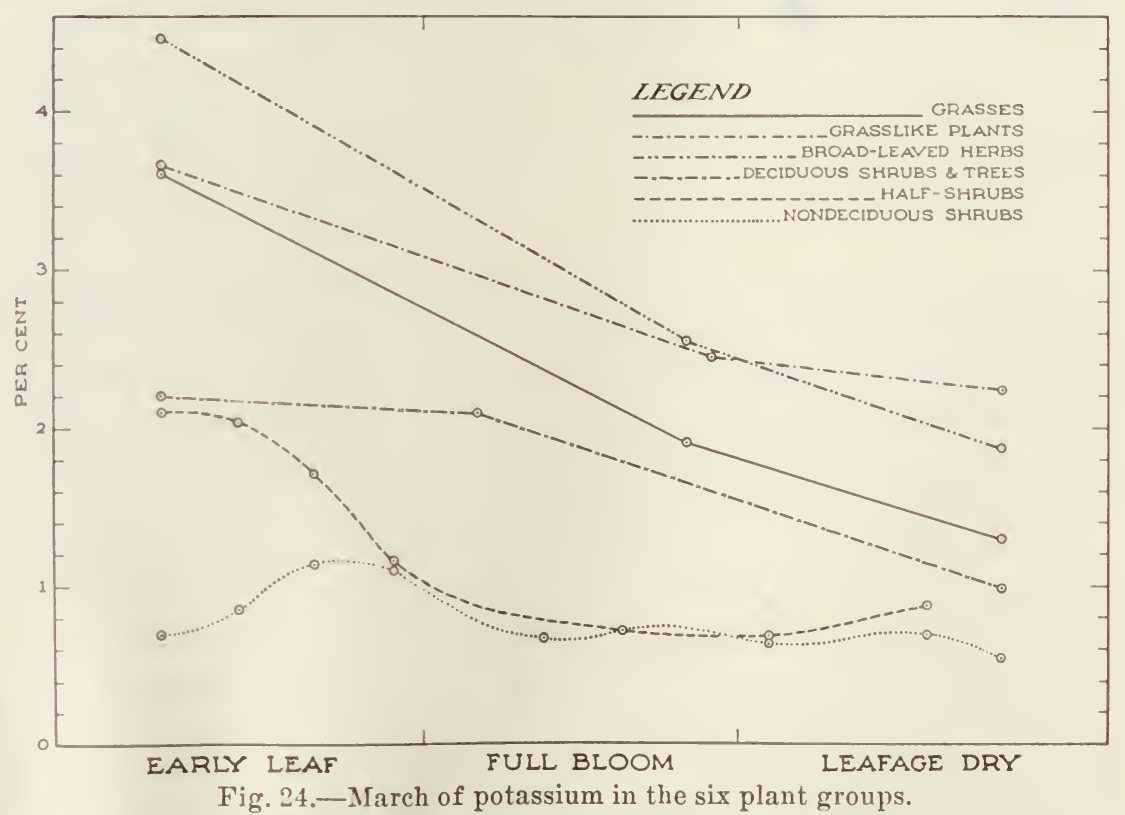


stage and lowest at leaf maturity; (3) in calcium and fiber the range is widest at leaf maturity; (4) the leafage of the deciduous shrubs and trees is relatively high among the groups in protein, phosphorus, and calcium, and is relatively low in crude fiber and potassium; (5) the nondeciduous shrubs are comparatively low in all constituents, except calcium; (6) the half-shrubs are low in protein, silica-free ash and its constituents, and are high in fiber; and (7) the broad-leaved herbs are approximately five times higher in calcium than the grasses and grasslike groups, slightly higher in protein, phosphorus, and potassium, and much lower in fiber.

A resumé of the march of the constituents in the six plant groups during the growing season is given in table 10 .

\section{APPLICATION TO RANGE MANAGEMENT}

Since these studies show that species and groups of species, exhibit characteristic chemical compositions, and that these change continuously and markedly with their seasonal development, the question arises as to the significance of this knowledge to practical range problems. Accordingly, the following inquiries are pertinent:

At what growth stage may the greatest energy and nutritive values of the different plant associations be procured, without jeopardy to the range?

What rôle of economic importance, if any, do the unpalatable or "weedy" species play in a range plant community?

Should the management of a range be so directed as to restore and maintain as nearly as possible the original plant cover, linked, as it is, with its characteristic soil type, or may there be a less planned utilization of the forage, resulting in the vegetation being naturally transformed into a single plant association, such as a purely herbaceous stand, or into a brush cover?

In what ways may knowledge of the march and the levels of the chemical composition of forage species serve in the recognition of the characteristics especially desirable in a forage species ?

Is it possible to predict the effect of a shortened growing season, such as may be induced by drought or unfavorable temperature, on certain specific nutritional values of the forage crop in such years?

May tables giving the chemical values of the dominant species at important growth stages, and the time involved in reaching these periods, be used, in conjunction with the survey of the botanical composition of the range, with a view to refining the estimates of its carrying capacity, as when a grazing reconnaissance is made? 
The discussion which follows, taken up in the order of questions raised, aims to point out how the results reported in this bulletin may throw some light on these and similar questions.

Comparative Forage Values of the Different Growth Stages.-Since these studies have shown that the composition of the range species changes greatly from the early leaf stage to maturity, it seems pertinent to compare, through the adoption of some standard, the values of the more essential constituents in the field samples at definite growth stages. For purposes of comparison 25 pounds ${ }^{14}$ of oven-dry weight of forage was taken as a standard weight in each of the three growth stages of the forage, namely, the early leaf stage, the flowering stage, and at full maturity. Table 11 gives, in pounds, the crude protein, crude fiber, silicafree ash, and phosphorus content in field samples equivalent to 25 pounds on the dry-weight basis as above stated. The object of the following computations is to show the respective nutritive values of forage at various growth stages when the water factor has been eliminated. Such comparisons should clarify the question of relative values of the young and the more mature forage.

Table 11 shows that in the early leaf stage the weight of the field sample equivalent to 25 pounds of dry material is much the highest, and the weight of the mature sample is much the lowest, whereas in the bloom period the weight is intermediate. In the grasses and broad-leaved herbs it will be noted that in the early leaf stage, despite the fact that the equivalent to 25 pounds of oven-dry weight of the field sample is much the largest-owing to high water content-the nutritional values are the highest for the entire season. Even when the blossom stage has been reached, and the moisture content has declined considerably, the daily poundage of the more essential constituents consumed by the animal, except in such annual grasses as Festuca megalura and Avena barbata, is still satisfactory. At maturity, on the other hand, when the field samples approach closely the weight of the oven-dry unit, the percentage composition of nutrients is the lowest, whereas in the period of inflorescence these values for most of the species are intermediate.

The deciduous species listed in table 11 show that the poundage of crude protein, computed on a 25 pound dry-weight ratio, is highest in the early leaf stage, and lowest, late in the autumn. At the latter period the poundage of protein amounts to about one-fourth of that contained in the young foliage. On the other hand, in the nondeciduous species, as typified in Ceanothus cuneatus, the protein ratios change little through

${ }^{14}$ Twenty-five pounds of dry forage was taken for convenience in these computations, and also because this figure approaches the daily requirement of a 1,000-pound animal. 
the season. In crude fiber the ratios in both of these plant groups show little variation through the grazing period, and is not a determining factor in their seasonal values.

The silica-free ash in the foliage of the deciduous species is greatest when the leaves are mature, whereas in the nondeciduous species, the ash

TABLE 11

Proportion of Constituents in Representative Field Forage Samples at Different Growth Stages, when Converted to the Equivalent OF 25 POUNDS OF OVEN-DRY WEIGHT*

\begin{tabular}{|c|c|c|c|c|c|c|c|}
\hline Species & Growth stage & $\begin{array}{c}\text { Water, } \\
\text { per cent }\end{array}$ & $\begin{array}{l}\text { Approx- } \\
\text { imate } \\
\text { forage } \\
\text { equiva- } \\
\text { lent, } \\
\text { pounds }\end{array}$ & $\begin{array}{l}\text { Silica- } \\
\text { free } \\
\text { ash, } \\
\text { pounds }\end{array}$ & $\begin{array}{l}\text { Phos- } \\
\text { phorus, } \\
\text { pounds }\end{array}$ & $\begin{array}{c}\text { Crude } \\
\text { protein, } \\
\text { pounds }\end{array}$ & $\begin{array}{l}\text { Crude } \\
\text { fiber, } \\
\text { pounds }\end{array}$ \\
\hline \multirow{3}{*}{ Avena barbata............ } & Early leaf........ & 77.0 & 109 & 2.0 & 0.09 & 5.3 & 4.7 \\
\hline & $\{$ Flowering............. & 71.0 & 86 & 1.1 & .09 & 1.8 & 8.6 \\
\hline & Mature, dry ............. & 5.0 & 26 & 1.3 & .06 & 0.5 & 9.8 \\
\hline \multirow{3}{*}{ Bromus mollis........... } & Early leaf............ & 83.0 & 147 & 3.0 & .12 & 5.6 & 6.2 \\
\hline & $\{$ Flowering...... & 75.0 & 100 & 1.4 & .11 & 3.0 & 7.5 \\
\hline & Mature, dry............ & 0.3 & 25 & 0.7 & .04 & 0.9 & 9.6 \\
\hline \multirow{3}{*}{ Festuca megalura......... } & (Early leaf ............. & 73.0 & 93 & 1.7 & .10 & 3.8 & 5.6 \\
\hline & $\{$ Flowering............. & 62.0 & 66 & 0.8 & .07 & 1.9 & 8.3 \\
\hline & (Mature, dry........... & 2.3 & 26 & 0.4 & .03 & 0.7 & 10.6 \\
\hline \multirow{3}{*}{ Melica imperfecta........ } & Early leaf. & 76.0 & 104 & 2.2 & .10 & 6.0 & 6.3 \\
\hline & $\{$ Flowering.... & 75.0 & 100 & 1.8 & .10 & 5.2 & 7.4 \\
\hline & Mature, dry ............. & 29.0 & 35 & 0.8 & .03 & 0.8 & 7.9 \\
\hline \multirow{3}{*}{ Juncus oxymeris......... } & Early leaf............. & 83.0 & 147 & 2.1 & .11 & 6.0 & 5.6 \\
\hline & $\{$ Flowering............ & 71.0 & 86 & 1.5 & .06 & 2.1 & 8.5 \\
\hline & Mature, dry............ & 3.0 & 26 & 1.3 & .02 & 0.9 & 9.0 \\
\hline \multirow{3}{*}{ Erodium botrys........... } & Early leaf.. & 87.0 & 192 & 3.5 & .10 & 6.7 & 2.7 \\
\hline & Flowering.... & 86.0 & 178 & 2.9 & .12 & 4.7 & 4.2 \\
\hline & Mature, dry ............ & 4.0 & 26 & 2.6 & .05 & 1.2 & 7.1 \\
\hline \multirow{3}{*}{ Ceanothus cuneatus...... } & (Early leaf (Feb.)....... & 54.0 & 54 & 1.4 & .04 & 3.2 & 2.4 \\
\hline & $\{$ Fully developed (May). & 54.0 & 54 & 1.3 & .04 & 2.8 & 3.1 \\
\hline & (Leaf hardened (Nov.)... & 46.0 & 46 & 1.4 & .03 & 2.7 & 2.6 \\
\hline \multirow{3}{*}{ Aesculus californica...... } & Early leaf... & 80.0 & 125 & 1.7 & .18 & 7.6 & 2.4 \\
\hline & Flowering...... & 78.0 & 114 & 2.5 & .12 & 5.8 & 2.3 \\
\hline & Mature, dry............ & 9.0 & 27 & 4.6 & .06 & 1.7 & 2.9 \\
\hline \multirow{3}{*}{ Quercus Douglasii........ } & Early leaf.. & 72.0 & 89 & 1.3 & .10 & 4.9 & 4.4 \\
\hline & $\{$ June............ & 61.0 & 64 & 1.4 & .06 & 3.5 & 3.6 \\
\hline & Mature............. & 37.0 & 40 & 1.6 & .04 & 2.4 & 3.2 \\
\hline \multirow{3}{*}{ Sambucus glauca.. } & Early leaf..... & 83.0 & 147 & 2.3 & .22 & 9.1 & 2.4 \\
\hline & $\{$ Flowering........ & 83.0 & 147 & 2.6 & .15 & 9.6 & 2.8 \\
\hline & Mature, dry........ & 8.0 & 27 & 3.8 & 0.02 & 1.7 & 2.4 \\
\hline
\end{tabular}

* Data from samples of different years were used in some cases to obtain the figures for comparative growth stages. 
fraction is greatest in early spring. In both groups, however, the poundage of phosphorus in a unit of dry weight is lighest in the young leafage and lowest at leaf maturity.

It is significant that when the grasses and the other herbaceous species are near or in the flowering stage, the crude protein, ash, and the phosphorus contents are still fairly high. Despite the fact that the forage is richest in most constituents in the very early leaf stage, grazing extensively, or to a point which would approach the full capacity of the range at this period, is for other reasons inadvisable. Very early seasonal grazing, especially if the photosynthetic surface is cropped down repeatedly, tends to decrease the yield of the season's forage erop. Repeated early grazing curtails not only the top growth but also the root development. To obtain the best general results on a herbaceous range the time to begin grazing appears to be between the earlier growth stage and the flowering period, when the roots liave become well established and are not readily trampled out of a wet or lonse soil.

Rôle of Weeds in a Range Community.-Ranqre species, because of the rigorous environment to which they have long been subjected, have brought about various alaptive responses. which have resulted in fitting them into their respective ecologieal niches. The strugrgle between the many plant species in a given range area is lieen indeed, and results in the elimination of the major proportion of the initial seedliner stand. In averaged counts of a square foot of surface, which is believed to be fairly typical of a well-stocked herbaceons eover of the San . Joquin and similar foothill range, more than 8,000 seellings, eomposed of many species, were recorded early in the season. Obviously, not all individuals of such a dense young stand could survive. Ouly the better-adapted forms could complete their life "yele.

Amoner the factors which detormine the survival of individuals, the soil solutiou appears to play a major part. Preliminary study of the soils of various plant rommunities of the san Joaquin Experimental Range revealed that the soil solution is generally of very low encentration. Accordingly, those species which have the highest absorptive capacity may be the ones which deternine the ultinate eharaeter of the stand.

From analytical data presented, it is seen that species which grow side by side differ greatly in the pereentage of the rarious elements. Thus in Amsinckia Douglusiana the total silica-free ash content in the early wrowth stages is approximately 20 per cent of the oven-dry weight of the plant; and the potassium coutent approximates 7 per cent-figures which are conspicuously higher than those in other species investigated. Accordingly, this speries has much greater absorptive capacity than most 
of its associates. Being largely unpalatable to livestock, it adds much organic matter and essential salts to the soil, factors which should reflect favorably upon the establishment and growth of associated species of quite different absorptive capacities. From the viewpoint of favorably influencing the soil for incoming plant species, then, some of the so-called "weedy" species may have a bearing in shaping the character of the plant community.

Soils in Relation to Plant Types and Forage Utilization.-Most range areas support a variety of forage species, but often these are composed largely of a single life form, such as grass or brush. The data here reported show that each of the various plant groups is characterized by distinctive nutritional patterns. The groups differ not only in the variations of the constituents throughout the growing season, but also in their levels.

Whether the soils, which support these different types of vegetation, are chiefly responsible for the distribution and the nutritional characteristics of the various plant groups on a given range is a subject for extensive investigation. The authors, however, have digressed from the main study to make limited examination of the soils in the sampling sites. It is hoped that the mere recognition of this phase may stimulate serious work on this complex problem.

From table 12 it is seen that the soil of a mixed cover of shrubs, trees, and herbs is richer in total nitrogen and in organic matter than is the soil of the pure grass stand. Areas sparsely vegetated with Lessingia germanorum and Festuca megalura, both of which are shallow-rooted (and inferior as forage), were found to have the lowest total nitrogen, nitrates, and organic material of the soil types investigated. The soil of the wet swale areas, on the other hand, with its dense and luxuriant growth of succulent grasslike species, while very low in nitrates, compares favorably with that of the shrub-tree-herb community in total nitrogen and organic matter ; this indicates low nitrifying power. In these swales, however, the total concentration of the soil solution was found to be higher in the deeper soil horizon, whereas the total organic matter was the greater in the upper soil layer, where the roots are largely found. The $\mathrm{pH}$ values of the soils worked with are only slightly on the acid side, except in the shrub-tree-herb community, where they drop to 5.99 .

It is worthy of note that the soil samples from the wet swale are characterized by a highly selective botanical composition, only a few species composing the bulk of the cover. Along the margin, where the drainage is good, the cover is composed of a combination of annual and perennial herbaceous species. During the three years of study these border species 
have not been observed to invade the true swale type to any appreciable extent. Since the soil of this area contains only a trace of nitrates (table 12), and is saturated with water during much of the growing season, the aeration is poor-factors evidently of sufficient magnitude to prevent invasions by species of the adjoining dry-land regetation.

In the moist, but well-drained meadow, which is conspicuously characterized late in the season by the robust Hemizonia virgata, and a

TABLE 12

Relation of Some Soil Characteristics to Plant Cover ox the San Joaquin Experianental Raxge

\begin{tabular}{|c|c|c|c|c|c|}
\hline Cover where sample was taken & $\begin{array}{l}\text { Denth of } \\
\text { soil sample, } \\
\text { inches }\end{array}$ & $\begin{array}{l}\text { Loss on } \\
\text { ignition, } \\
\text { per cent }\end{array}$ & $\begin{array}{l}\text { Total } \\
\text { nitrogen, } \\
\text { per cent }\end{array}$ & $\begin{array}{l}\text { Nitrate } \\
\text { nitrogen, } \\
\text { p.p.m. }\end{array}$ & $\mathrm{pH}$ \\
\hline $\begin{array}{l}\text { Mixed cover of trees, brush, grass, } \\
\text { broad-leaved herbs ..... }\end{array}$ & $\begin{array}{l}0-8 \\
8-30\end{array}$ & $\begin{array}{l}2.92 \\
2.33\end{array}$ & $\begin{array}{r}0.194 \\
.116\end{array}$ & $\begin{array}{l}3.0 \\
0.7\end{array}$ & $\begin{array}{l}5.99 \\
6.30\end{array}$ \\
\hline Swale of grasslike species & $\begin{array}{l}0-5 \\
8-30\end{array}$ & $\begin{array}{l}2.51 \\
2.02\end{array}$ & $\begin{array}{l}.195 \\
.065\end{array}$ & $\begin{array}{c}0.5 \\
\text { trace }\end{array}$ & $\begin{array}{l}6.62 \\
6.80\end{array}$ \\
\hline $\begin{array}{l}\text { Grass cover with scattered, broad- } \\
\text { leaved herhs. }\end{array}$ & $\begin{array}{l}0-5 \\
5-30\end{array}$ & $\begin{array}{l}1 \text { i9 } \\
2 \text { it }\end{array}$ & $\begin{array}{l}.103 \\
.090\end{array}$ & $\begin{array}{l}0.5 \\
2.0\end{array}$ & $\begin{array}{l}6.72 \\
6.57\end{array}$ \\
\hline $\begin{array}{l}\text { Lessingia and annual fescurs, } \\
\text { sparse cover.... }\end{array}$ & $\begin{array}{l}0-5 \\
-30\end{array}$ & $\begin{array}{ll}2 & 12 \\
1 & 63\end{array}$ & $\begin{array}{l}.09 \\
.053\end{array}$ & 0.5 & $\begin{array}{l}6.50 \\
6.64\end{array}$ \\
\hline $\begin{array}{l}\text { Swale of Ilemizonia, Trifolium, and } \\
\text { Eremocarpus (drying in late spring) }\end{array}$ & $0-5$ & 2.36 & 0.147 & 4.0 & 6.14 \\
\hline
\end{tabular}

scattering of Trifolium tridentatum and Ercmocarpus sctigerus, there are to be found oceasional robust specimens of the species which dominate the marginal and the well-drained adjoining slopes. Since this meadow soil is well aerated, nitrification is presumably active, and there is ample $\mathrm{NO}_{3}$, amounting to some 4 parts per milliou. Moreover, the total organic matter and total salts are of much the same magnitude as in the soil of the shrub-tree-herb association. Evidently, therefore, if it were not for the keen competition set up by Hemizonia virgata, and the few other associated species, the adjoining hillside regretation would presumably completely oceupy this area.

These two examples of elosed, or so-ealled "unyielding" communities, illustrate well some of the more conspicuous factors which determine the delimitations of plant associations. In the wet swale of the grasslike cover, the poor aeration and the general character of the soil evidently determine the plant population. Indeed, even if this cover were removed the neighboring hillside species presumably could not come in. These swale species, then, serve as indicators of distinctive soil cliaracteristics. The 
Hemizonia virgata area, on the other hand, illustrates the play of quite a different set of factors in the determination of the stand. Here the character of the soil is probably much less a potent factor than is the presence of the exceedingly aggressive and well adapted dominant species which compose the present vegetation. If, in this site, the more distinctly meadow type of vegetation were removed, it is reasonable to assume that the adjoining hillside species would occupy the area.

In the light of these plant behaviors it appears that the soil solution, in combination with other edaphic factors, notably moisture supply, may have an important bearing on the ultimate character of the plant cover. The subject of sequence of species on developing soils, or on areas where the upper soil horizon is being gradually removed, appears worthy of critical study.

Criteria for Judging the Value of a Forage Plant.-Knowledge of the march of the chemical composition of range plants makes possible the segregation of the species into two broad categories: those having relatively high nutritive values; and those of consistently low values. Although such information is valuable, it does not afford a sufficiently broad index to segregate the species into their respective economic categories. Aside from the factor of palatability, some species which are high in the essential constituents may be of relatively little value because of their short growth cycle. Species like Lessingia germanorum, because of the low levels of their nutrients throughout the growth period, can be classed as undesirable purely on the basis of chemical studies. Festuca megalura, on the other hand, when in the early leaf stage, ranks in nutrients with those of desirable grass species; but the life cycle of this species is so short as to place it among the most undesirable of range grasses. Thus the criteria for judging the economic rank of a palatable range plant is that of high nutritive value maintained through the life cycle, preferably in addition to a long period of vegetative growth. Most of the perennial grasses investigated mature relatively late in the season, a behavior commonly associated with high nutritiveness well into the autumn. Knowledge of the seasonal change of composition of the forage species, therefore, must be considered in addition to data pertaining to the length of the growth cycle of the individual species, in classifying them as to relative range values.

Shortening of Growing Season as Affecting Nutritive Values.-It is not uncommon, particularly in the foothill and valley regions of the state, that deficient autumn or winter rains, or unfavorable temperature, may retard the inception of growth by several weeks. Since the present study, although based solely on nursery plots, appears to show that a 
short growing season results in lower values for phosphorus, and in some species, for calcium, and in somewhat higher levels for crude fiber, it would appear that such abnormal years would be associated with poorer quality of forage.

Although the present investigation has not included regetation of the high mountain ranges, the results here reported lead one to suspect that the forage there produced, associated as it is with a short growing season. might be low in phosphorus. Especially may this be the case in years when the snowfall is so heavy as appreciably to delay the beginning of growth.

Chemical Values and Grazing Capacity.-The present reconnaissance methods used in estimating the grazing eapacity of a range admittedly are in need of refinement. Failure to obtain uniformly reliable estimates may partly be accounted for by the fact that the nutritive value of the forage changes from month to month and does not reach some degree of stability until late in the summer. Also the data obtained for carringcapacity estimates do not take into account the relative quantities of the constituents of the different forage types, and therefore do not take into account the nutritional balance in the forage as a whole.

Possibly grazing capacity estimates could be refined by taking into account the following factors : botanical composition of a forage type, expressed in weight of air-dry herbage; the average palatability of each plant group, such as grasses, hroarl-leaved herbs, browse, ete.; the average length of the growing season of each forage type; and the averaged march of emposition in each plant group. Thus if it is assumed that one acre of a grass type, when in the early growth stage, produces one-fourth ton of air-dry material, 90 per cent of which is palatable, then 450 pounds of such forage could be utilized. The protein content, as read from a prepared nutritional curve, is taken as 20 per cent for purposes of calculation, which gives 90 pounds of this constituent for the area. Estimates of weight increase in the air-dry forage as the season advances, accompanied as it is by a eorresponding decline in erude protein, could readily be calculated from the curve for the type at any time in the season. In the same way the nutrient values for a unit area enuld be derived for other important ennstituents. Repetition of this method for each type would furnish data as to the total nutrients available at any time in the season. With the inclusion of such data in the reconnaissance computations would appear to furnish more exacting estimates of the carrying capacity of a range. This deduction is offered with the hope that a qualified reconnaissance worker may beeome sufficiently interested to include in his equation the factors above enumerated. 


\section{SUMMARY}

The study of foothill range plants, with special reference to the seasonal march in their composition, was conducted on field and nursery sample plots of the San Joaquin Experimental Range. The dominant vegetation is believed to be fairly characteristic of the extensive savanna-woodland association.

Review of the literature here cited reveals the fact that much confusion exists relative to the changes in composition of forage species. The fact that there is a high percentage of crude protein, and a low percentage of crude fiber in the early growth stages, followed by gradual decline in the former and increase in the latter with advance in the season, has already been fairly well established; but the trend in the ash content, and its constituents, during the life history of range plants, requires further investigation. Some significant data on this phase are reported in this paper.

The samples of most species were collected at distinct growth stages, irrespective of chronological dates; the majority of previous workers have collected the samples according to established dates.

In most of the graminaceous, grasslike, and broad-leaved herbaceous species there is a continuous and rather orderly decline in the crude protein, the silica-free ash, calcium, phosphorus, and potassium from the earliest appearance of leaf blades to plant maturity. The percentage of crude fiber in these plant groups, on the other hand, increases with the advance of the season. The most rapid changes in constituents take place from the early leaf development to the period of full bloom.

Although species within a plant group have characteristic compositional levels, the variation in chemical values in the entire life cycle of plants of a given species is greater than that between the various species of the plant group for any single growth stage.

The levels of protein in the three herbaceous groups (grasses, grasslike plants, and broad-leaved herbs) at corresponding growth stages are of similar values ; but the levels in crude fiber in the broad-leaved herbs are lower, on the average, than in the two other herbaceous groups.

In silica-free ash, calcium, and potassium, the broad-leaved herbs maintain a higher level throughout the entire season than do the grasses and grasslike species. In phosphorus content the values in these three groups are much the same at corresponding growth stages. The grasslike species are characterized by high silica content.

The crude protein in the foliage of the deciduous shrubs and trees declines in an orderly way from the earliest appearance of the leaves to 
their maturity. The protein levels in this group are the highest of the various groups studied. In the deciduous half-shrubs and the nondeciduous shrubs the protein levels change relatively little, and are the lowest of the six groups. The crests and depressions of the curres of these two groups are determined by the relative amounts of the young and mature foliage in such vegetation.

The crude fiber in the foliage of the deciduous shrubs and trees, and in the nondeciduous shrubs, maintains nearly the same level throughout the season, and is the lowest in any of the groups studied. In the deciduous half-shrubs the level of the fiber while rariable, is the lighest of these three groups, the maximum amount being reached in midsummer.

In silica-free ash, and in calcium content, the foliage of the deciduous shrubs and trees stands out in contrast to all the other plant groups in that the trend is distinctly upward with advancement in the season, and these constituents are much higher than in the other two groups of woody plants. In the nondeciduous shrubs and the deciduous half-shrubs, the ash and calcium contents vary throughout the season, the levels being governed by the proportion of young foliage in the sample. These two constituents are the lowest in the deciduous half-shrubs.

The trend in potassium content in the three groups of woody plants is distinctly downward with increasing age of the foliage. In contrast to the herbaceous speeies, the potassium content takes seend place quantitatively to that of calcium.

The phosphorus content declines gradually from the early leaf stage to leaf maturity. The phosphorus levels of the deciduous and nondeciduous half-shrubs are the lowest of any of the plant groups studied.

There is an impressive consisteney in the composition of all constituents within a species through the growth cycle from year to year.

Some of the "weedy," or largely unpalatable species, have a high absorption capacity and are conspicuously rich in certain essential elements. Aceordingly some such species may play an important part in determining the character of the plant cover in subsequent years.

The calcium-phosphorus ratio shows characteristic behavior in the respective plant groups. In the grasses this ratio remains close to 1 to 1 at all growth stages; in the grasslike species it is about 1 to 1 in the early leaf stage and 4 to 1 at maturity; in the broad-leaved herbs the average ratio is approximately 2 to 1 early in the season and 12 to 1 at late maturity; in the nondeciduous shrubs the ratio is approximately 5 to 1 in the early leaf stage and 16 to 1 late in the autumn. In the deciduous shrubs and trees the ratio varies most, averaging approximately 1 to 1 in the early leaf stage and 28 to 1 at leaf maturity. 
Shortening of the growing season apparently results in a decrease in phosphorus, and in some species in calcium, but it does not influence quantitatively the protein and potassium contents. Enrichment of the soils concerned, as through application of manure, on the other hand, results in a higher percentage of crude protein and phosphorus, and a lower percentage of crude fiber.

The seeds of the grasses and the broad-leaved herbs, as compared with the mature leafage, have approximately the same values in calcium, whereas the phosphorus content is higher, and the potassium content is lower. The seeds of the shrubs and trees, on the other hand, are lower in calcium than the mature foliage, whereas the levels of the phosphorus and potassium are nearly the same as in the foliage.

These studies reveal that a valuable range plant, among other things, must have a long vegetative period, or the nutritional values of the mature herbage must be maintained at a high level well after seed formation. This viewpoint is helpful in the classification of range plants as to their economic values.

For a given unit of dry matter the early season growth has a higher caloric value, and is richer in ash and its constituents, than the mature leafage.

Knowledge of chemical values of range species, especially if considered in relation to their respective soils, should prove helpful in explaining plant succession.

A diversified plant cover is preferable for stabilization of nutritive forage values to that of a single plant type.

Knowledge of the chemical values of the dominant species, with their seasonal changes should prove useful as a factor in perfecting more dependable methods for estimating the carrying capacity of the range.

\section{ACKNOWLEDGMENTS}

The writers wish to make grateful acknowledgment to the following persons, all of the California Forest and Range Experiment Station of the United States Forest Service: To Station Director E. I. Kotok, and to M. W. Talbot, Senior Plant Ecologist, for valuable suggestions in the organization of the work plan and in making available laboratory and other facilities at the San Joaquin Experimental Range; to Dr. Harold H. Biswell, Assistant Conservationist, for invaluable assistance in collecting forest samples and for help in many other ways ; and to Assistant Station Director Dr. J. A. Hall for critically reading the manuscript. The spirit of coöperation and helpfulness is greatly appreciated. 


\section{LITERATURE CITED}

1. Austin, Stanley.

1933. Tegetation and reproduction in the soy bean. Science 78:363-64.

2. Austin, Stanley.

1935. Effects of exfloration on plant metabolism. Plant Physiol. 10:225-43.

3. BURD, J. S.

1919. Rate of absorption of soil constituents at successive stages of plant growth. Jour. Agr. Research 18:51-72.

4. CAPEN, R. G., and J. A. Le Clerc.

1933. Chemical composition of native Alaskan hays harvested at different periods of growth. Jour. Agr. Research 46:665-68.

5. Cooper, H. P.

1930. Ash constituents of pasture grasses, their standard electrode potentials and ecological significance. Plant Physiol. 5:193-214.

6. Czapek, Friedricit.

1922. Biochemie der Pflanzen. Vol. 1, 3d ed. 828 p. G. Fischer, Jena.

7. DANiEL, H. A.

1934. The calcium, phosphorus, and nitrogen content of grasses and legumes; and the relation of these elements in the plant. Jour. Amer. Soc. Agron. $26: 496-503$.

8. Daniel, Harley A., and Horace J. Harper.

1934. The relation between total calcium and phosphorus in mature grass, prairie grass and available plant food in the soil. Jour. Amer. Soc. Agron. $26: 986-92$.

9. Davis, A. R., D. R. Hodglaxd, and C. B. Lipuiav.

1923. The feeding power of plants. Science $57: 299-301$.

10. Du Tort, P. .T., .T. G. Louw, and A. I. Malax.

1935. The influence of season and frequeney of eutting on the yicld, persisteney, and chemical composition of grass species. Onderstepoort Jour. Vet. Sei. and Animal Ind. 5:215- 70 .

11. FAGAN, T. W., and H. T. WATKINS.

1932. The elemical composition of the misecllaneous herhs of pastures. Wolsh Jour. Agr. 8:144-51.

12. Ferguson, W. S.

1931. Investigations into the intensive system of grassland management. $11 \mathrm{I}$. The seasonal variation in the mineral content of pasture with particular reference to drought. Jour. Agr. Sci. 21:233-40.

13. Forbes, F. B., A. C. Whitrier, and R. C. Collison.

1910. The mineral nutrients in blue grass. Ohio Exp. Sta. Bul. 222:39-53.

14. Franklis, M. C.

1932. Mineral content of some Canterbury pastures. New Zealand Jour. Sci.

Tech. 13:244-52.

15. Graber, L. F.

1929. Penalties of low food reserves in pasture grasses. Jour. Amer. Soc. A gron. $21: 29-33$. 
16. Graber, L. F., N. T. Nelson, W. A. Leukel, and W. B. Albert.

1927. Organic food reserves in relation to the growth of alfalfa and other perennial herbaceous plants. Wisconsin Agr. Exp. Sta. Research Bul. 80: $1-128$.

17. Greenhill, A. W., and H. J. Page.

1931. Investigations into the intensive system of grassland management. II. The mineral content of intensively treated pasture and a relationship between the nitrogen and phosphorus contents. Jour. Agr. Sci. 21:220-32.

18. Guilbert, H. R., and S. W. Mead.

1931. The digestibility of bur clover as affected by exposure to sunlight and rain. Hilgardia 6:1-12.

19. Guilbert, H. R., S. W. Mead, and H. C. Jackson.

1931. The effect of leaching on the nutritive value of forage plants. Hilgardia $6: 13-26$.

20. Hall, A. D., and E. J. Russell.

1912. On the causes of the high nutritive value and fertility of the fattening pastures of Romney marsh and other marshes in the S.E. of England. Jour. Agr. Sci. 4(Part 4):339-70.

21. HARrison, C. M.

1931. Effect of cutting and fertilizer applications on grass development. Plant Physiol. 6:669-84.

22. Hart, G. H., H. R. Guilbert, and H. Goss.

1932. Seasonal changes in the chemical composition of range forage and their relation to nutrition of animals. California Agr. Exp. Sta. Bul. 543:1-62.

23. Hissink, D. J.

1930. Relation among soil, fertilizers, and chemical composition of plants. Chem. Weekblad 27:529-33.

24. Hoagland, D. R.

1919. Relation of the concentration and reaction of the nutrient medium to the growth and absorption of the plant. Jour. Agr. Research 18:73-117.

25. Hopper, T. H., and L. L. NesbitT.

1930. The composition of some North Dakota pasture and hay grasses. North Dakota Agr. Exp. Sta. Bul. 236:3-38.

26. INGLE, H.

1908. The mineral constituents of foods. Jour. Agr. Sci. 3:22-31.

27. $\mathrm{J}_{\mathrm{ACOB}}$, VoN A.

1935. Der Einfluss der Kalidungung auf die chemische Zusammensetzung der Ernteprodukte. Ztschr. für Pflanzenernährung, Düngung und Bodenkunde. 37:1-26.

28. KAUTER, A.

1935. Der Aschengehalt des Heugrases in seiner Abhängigkeit von Pflanzenbestand und Bodenreaktion. Landw. Jahrb. Schweiz 49:69-86. (French summary.)

29. Killian, CH.

1931. Etudes écologiques sur la réparation du chlorure de sodium dans les psammophytes et halophytes algériens. Ann. Physiol. et Physiocochim. Biol. $7(3): 419-68$. 
30. Kuttner, T., and H. R. CoHeN.

1927. Micro colorimetric studies. Jour. Bio. Chem. 75:517-31.

31. MCCALL, R.

1932. Seasonal rariation in composition and digestibility of certain species of range bunch grasses. Amer. Soc. Animal Product. Proc. 25:95-100.

32. MCCarti, E. C.

1932. Some relations between carbolısdrates and growth rate in wild oat, Avena fatua. Occasional papers of Riverside Junior College (Califormia) 6:1-32.

33. MCCREART, O.

1927. Wyoming forage plants and their chemical composition. Studies No. S. Wyoming Agr. Exp. Sta. Bul. 157:91-106.

34. McHargue, J. S., and W. R. Ror.

1932. Mineral and nitrogen content in leaves of some forest trees at different times in the growing season. Bot. Gaz. 94:3\$1-?3.

35. McHargue, J. S., W. R. Ror, and J. C. Pet.pirey.

1932. The iron, manganese, copper, zine, and iodine content of some important forage crops. Jour. Amer. Soc. Agron. 24:562-65.

36. Mortimer, G. B., and H. L. A Migrex.

1936. Influence of fertilization, irrigation, and stage and height of eutting on yield and composition of lientueky blue grass (Poa pratensis). Jour. Amer. Soc. Agron. 28:515-33.

37. MURNEEK, A. F.

1926. Reproduction and metabolic eficiency in the tomato. Missouri Agr. Exp. Sta. Research Bul. 90:1-19.

38. MURNEEK, A. E.

1932. Growth and development as influeneed $1 \mathrm{y}$ fruiting and seed formation. Plant Physiol. 7:79-?0.

39. Pierre, W. H., and G. G. Pohlasas.

1933. Preliminary studies of the exnded plant sap and the relation between the composition of the sap and the soil solution. Jour. Amer. Soc. Agron. $25(2): 144-60$.

40. Riciardson, A. E. V., H. C. Truami.e, and R. E. shaptrak.

1932. The infuence of growth stage and frequeney of eutting on the yield and composition of a perennial grass Phalaris tubcrosa. Australia. Council Sci. Ind. Research Bul. 66:1-35.

41. Roвеrts, E. N.

1926. Wyoming forage plants and their chemical composition, Studies No. 7. Effect of altitude, seasonal variation and shading experiments. Wyoming A gr. Exp. Sta. Bul. 146:35-39.

42. Sampson, A. W., and F. C. McCarty.

1930. The carbohydrate inetabolism of Stipa pulchra. Hilgardia 5:61-100.

43. SAMPson, A. W., and K. W. PARKF.r.

1930. St. Johnswort on range lands of California. California Agr. Exp. Sta. Bul. $503: 1-49$,

44. SAMPSON, A. W., and R. SAMISCII.

1935. Growth and seasonal changes in composition of oak leaves. Plant Physiol. 10:739-51. 
45. Seiden, $R$.

1926. Comparative investigations on the influence of different external factors, especially upon the ash content of plants. Landw. Vers. Sta. 104:1-50.

46. Sharrer, K., and K. KürSCHNER.

1931-32. Ein neues, rasch Durchführbares verfahren zur Bestimmung der Rohfaser in Futtermitteln. Die Tierernahrung (now: Biedermann's Zentralblatt für Agrikulturchemie und rationellen Landwirtschaftsbetrieb. Abt. B) $3: 302-10$.

47. Stapledon, R. G., T. W. Fagan, R. E. Evans, and W. E. J. Milton.

1927. Italian rye grass for winter and early spring keep: The effects of methods of grazing on productivity and palatability, and on the chemical and botanical composition of the herbage. Welsh Plant Breed. Sta. Bul. Series H, No. 5:1-54.

48. Truninger, E., and F. V. Grunigen.

1936. Ueber den Mineralstoffgehalt einiger unserer wichtigsten Wiesenpflanzen mit besonderer Berucksichtigung der physiologischen Bedeutung des Kalis im Wiesenfutter. Landw. Jahrb. der Schweiz 49:101-27.

49. Van ItTallie, TH. B.

1934. De chemische samenstelling van een aantal afzonderlijke grassoorten in verschillende groeistadia. Verslagen van Landbouwk. Onderzoekingen 40:639-93.

50. Watkins, W. E.

1937. The calcium and phosphorus contents of important New Mexico range forages. New Mexico Agr. Exp. Sta. Bul. 246:1-75.

51. Wilfrath, H., H. Romer, and G. Wimmer.

1906. Über die Nährstoffaufnahme der Pflanzen in verschiedenen Zeiten ihres Wachstums. Landw. Vers. Sta. 63:1-70.

52. Woodman, H. E., D. B. Norman, and M. H. French.

1931. Nutritive value of pasture. VII. The influence of the intensity of grazing on the yield, composition and nutritive value of pasture herbage. Jour. Agr. Sci. 21:267-321. 
